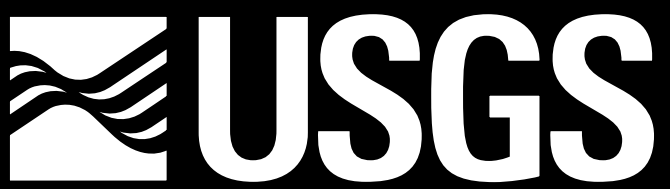

science for a changing world

\title{
AGE AND PALEOENVIRONMENTAL SIGNIFICANCE OF MEGA-INVERTEBRATES FROM THE "SAN PEDRO" FORMATION IN THE COYOTE HILLS, FULLERTON AND BUENA PARK, ORANGE COUNTY, SOUTHERN CALIFORNIA
}

By

Charles L. Powell, II ${ }^{1}$ and Dave Stevens ${ }^{2}$ ${ }^{1} 345$ Middlefield Rd., M/S 975, Menlo Park, CA 94025 ${ }^{2} \mathrm{RMW}$ PaleoAssociates, Mission Veijo, CA 92691

Open-File Report 00-319

U.S. DEPARTMENT OF THE INTERIOR U.S. GEOLOGICAL SURVEY 


\section{AGE AND PALEOENVIRONMENTAL SIGNIFICANCE OF MEGA-INVERTEBRATES FROM THE "SAN PEDRO" FORMATION IN THE COYOTE HILLS, FULLERTON AND BUENA PARK, ORANGE COUNTY, SOUTHERN} CALIFORNIA

By

Charles L. Powell, II and Dave Stevens

2000

OPEN-FILE REPORT 00-319

To obtain this report, contact: USGS Information Service

Box 25286

Denver Federal Center

Denver, CO 80225

(303) 202-4700

(303) 202-4693 FAX

or from the web at http://wrgis.wr.usgs.gov/open-file/of00-319

This report is preliminary and has not been reviewed for conformity with U.S. Geological Survey editorial standards or with the North American Stratigraphic Code. Any use of trade, product, or firm names is for descriptive purpose only and does not imply endorsement by the U.S. Government. 


\section{CONTENTS}

Abstract

Introduction

Stratigraphy of the "San Pedro" Formation

General

Physical stratigraphy

West Coyote Hills

East Coyote Hills

Previous paleontological studies of the "San Pedro" Formation in the Coyote

Hills

Faunal composition and paleoecology

Faunal composition and preservation 12

Paleoecology

Restricted fauna

Upper fauna

Middle fauna

Pliocene fauna

Age

Paleontologic age

Restricted fauna

Upper fauna

Middle fauna

Pliocene fauna

Radiometric dating

Conclusions

\section{Acknowledgements}

Appendix 1.- Selected faunal notes

Appendix 2.-Fossil localities and faunal lists

Los Angeles County Museum of Natural History

Ralph B. Clark Regional Park

Claremont College, Department of Geology (Pomona College)

RMW Paleo Associates

50

Yerkes (1972)

Figures

Fig. 1. - Index map of outcrops areas of the "San Pedro" Formation in the Coyote Hills, Orange County, California. The map covers approximately the lower third of the USGS La Habra 7.5' quadrangle (1964 ed., 1981 photorevised).

Fig. 2.-Composite stratigraphic section for the northern West Coyote Hills with fossil localities and environmental interpretations

Fig. 3a.-Composite stratigraphic section of approximately the top half (some overlap) for the Ralph C. Clark Regional Park (southern West Coyote Hills) with rock stratigraphic units, fossil localities, and environmental interpretations 
Fig. 3b.--Composite stratigraphic section of approximately the bottom half (some overlap) for the Ralph C. Clark Regional Park (southern West Coyote Hills) with rock stratigraphic units, fossil localities, and environmental interpretations from mollusks

Fig. 4.--Composite stratigraphic section for the East Coyote Hills with rock stratigraphic units, fossil localities, and environmental interpretations from mollusks

Fig. 5.-Correlation chart of stratigraphic sections in the northern West Coyote Hills, southern West Coyote Hills (Ralph C. Clark Regional Park), and East Coyote Hills

Fig. 6.-Fossil localities in the northern West Coyote Hills

Fig. 7.-Fossil localities in the southern West Coyote Hills (including Ralph C. Clark Regional Park)

Fig. 8.-Fossil localities in the eastern West Coyote Hills

Fig. 9.-Fossil localities in the East Coyote Hills

Tables

Tbl. 1.-Molluscan taxa reported from the "San Pedro" Formation in the Coyote Hills, Orange County, southern California

Tbl. 2.-Stratigraphic ranges of extinct taxa recovered from the upper, warm water, fauna in the West Coyote Hills, Orange County, California

Tbl. 3.-Stratigraphic ranges of extinct taxa from the middle, cool water, fauna in the Coyote Hills, Orange County, California

Tbl. 4.-Stratigraphic ranges of extinct mollusks from the lower, Pliocene, fauna in the East Coyote Hills, Orange County, California 


\section{ABSTRACT}

The "San Pedro" Formation in the Coyote Hills contains an invertebrate fossil assemblage of 184 taxa from 158 localities. The fauna consists of two annelids, 174 mollusks (80 bivalves, 94 gastropods, and three scaphopods), five arthropods, and three echinoids, along with other minor constituents recognized by not specifically identified during the present study. These fossils are divided into three assemblages; 1 ) a lower, Pliocene assemblage (which may not differ ecologically from the middle fauna), 2) a middle, cool water assemblage, and 3) an upper, temperate to warm water. These fossils suggest a probably late Pliocene to early Pleistocene age for outcrops of the "San Pedro" Formation in the Coyote Hills. A fourth assemblage with a limited, restricted marine fauna occurs in the overlying Coyote Hills Formation.

The occurrence of Solamen columbianum (Dall) (Mollusca: Bivalvia) in the "San Pedro" Formation of the Coyote Hills marks its first occurrence as a fossil. The oldest fossil occurrence of the gastropods Tegula pulligo (Gmelin), questionably Haliotis cracherodii Leach, and the crustacean Randallia ornata (Randell) occurs in the "San Pedro" Formation in the Coyote Hills.

\section{INTRODUCTION}

Paleontologically, late Pliocene to early Pleistocene outcrops in the Los Angeles Basin are little studied. Outcrops in and around the Coyote Hills in Orange County (Figure 1) are examined here for the purpose of developing a chronostratigraphy for the Quaternary of southern California based on successive molluscan faunas. A chronostratigraphy has already been partially completed for the later Quaternary (Powell, Lajoie, and Ponti, in press) but few studies have been undertaken on early Quaternary deposits in the Los Angeles Basin.

The "San Pedro" Formation in the Coyote Hills, Orange County, contains a molluscan assemblage of 174 taxa (80 bivalves, 94 gastropods, and three scaphopods; Table 1; Appendix 2) collected from 158 localities. In addition foraminifers, annelid worms, bryozoans, echinoids, arthropods, and vertebrates are known from these collections. Fossils from the "San Pedro" Formation are divided into two main faunas: an upper, temperate to warmwater fauna and a middle, cool-water fauna. A third fauna may be present which is similar to the middle fauna but is presumably older. Likewise the Formation is divided into two informal members, but these members are not coincident with the two, or possibly 3 , faunal assemblages. Exposures of the "San Pedro" Formation occur fairly extensively in the West Coyote Hills (including Ralph Clark Regional Park) reaching a maximum thickness of nearly $100 \mathrm{~m}$. In the East Coyote Hills, the formation thins, reaching a maximum thickness of only $20 \mathrm{~m}$.

The upper, temperate, faunal assemblage is not well dated, but contains Chlamys anapleus Woodring which suggests a middle Pleistocene age, and Pecten bellus (Conrad) which suggests a late Pliocene to early Pleistocene age. The data presented below suggests for an age range extension for $C$. anapleus Woodring to the early Pleistocene. The upper fauna contains two extra-limital southern taxa, which do not currently occur north of Baja California Norte, Mexico [i.e., Argopecten ventricosus (Sowerby) and Trachycardium panamense (Sowerby)]. In addition to the extra-limital taxa, the bivalve mollusks Chione spp., Donax californicus Conrad, Gari fucata (Hinds), and the gastropods Bursa californica (Hinds), Crucibulum spinosum (Sowerby), Nassarius sp., cf. N. cerritensis (Arnold), and Terebra pedroana Dall suggest warmer water conditions than the cool faunal assemblage 
recognized elsewhere in the Coyote Hills. This warm water fauna has been recognized only in the West Coyote Hills.

The middle, cool, faunal assemblage contains several extinct taxa, which suggest early Pleistocene, or possibly late Pliocene age. The fauna also contains two cooler water taxa which do not occur today south of about $36^{\circ} \mathrm{N}$ along the central California coast [i.e., Patinopecten caurinus (Gould) and Pandora wardiana Adams]. The cool-water nature of this fauna might correlate with a sea-level lowstand during the early part of the Pleistocene. This fauna is characterized by the occurrence of the bivalve mollusks Cyclocardia sp., cf. C. occidentalis (Conrad), Panope abrupta (Conrad), Patinopecten caurinus (Gould), Pecten bellus (Conrad), the gastropods Crassispira zizyphus Berry, and Crepidula princeps (Conrad), and the echinoid Dendraster venturaensis Kew. This fauna includes the oldest record of the gastropod Tegula pulligo (Gmelin), the crustacean Randellia ornata (Randell), and possibly the gastropod Haliotis cracherodii Leach.

A possible lower fauna was recovered from one collection from the East Coyote Hills. It does not appear to differ ecologically from the middle fauna except that it lacks extra-limital cool water taxa. It does, however contain several extinct taxa which suggest a late Pliocene age.

The following abbreviations are used in the text below:

$\begin{array}{ll}\text { F } & \begin{array}{r}\text { Cited in Yerkes (1972) Some of these collections are from } \\ \text { Hoskins (1954). }\end{array} \\ \text { LACMIP } & \begin{array}{r}\text { Los Angeles County Museum of Natural History, } \\ \text { Invertebrate Paleontology section, Los Angeles, } \\ \text { California. }\end{array} \\ \text { PC } & \text { Claremont Graduate School (formerly Pomona College), } \\ \text { Claremont, California. Hoskins (1954) collections. } & \text { RBCRP } \\ \text { RMW } & \text { Ralph B. Clark Regional Park, Buena Park, California. } \\ \text { UCR } & \text { RMW Pale Associates, Inc., Mission Viejo, California. }\end{array}$

\section{STRATIGRAPHY OF THE “SAN PEDRO” FORMATION General}

Dall (1898) first used the name "San Pedro beds" for sediments in the vicinity of the town of San Pedro. However it is unclear if he was referring to what is now known as the San Pedro Sands, Palos Verdes Sands, or both (fide Woodring and others, 1946). The San Pedro Sands of Woodring and others (1946) [=lower "San Pedro" Formation of Arnold and Arnold (1902) and Arnold (1903)] was described from sections on Deadman Island with supplemental outcrops along the San Pedro waterfront. Woodring and others (1946) regarded the entire San Pedro area as the type section probably because Deadman Island had been destroyed in 1928 and both Deadman Island and the San Pedro waterfront are referred to by Arnold and Arnold (1902). Kew (1923) follows the usage of Arnold (1903) referring to an upper and lower member of the San Pedro Formation separated by an unconformity. Woodring and others (1946) define the San Pedro Sands as occurring between the underlying Timms Point Silt and Lomita Marl and the overlying Palos Verdes Sands, although recent work by Ponti (1989) suggest that the three lower formations (Timms Point Silt, Lomita Marl, and San Pedro Sands) are approximately coeval and lie, in part, adjacent to one another. These formations, with the exception of the Palos Verdes Sands, were considered early Pleistocene by Woodring and others (1946), but recent work 


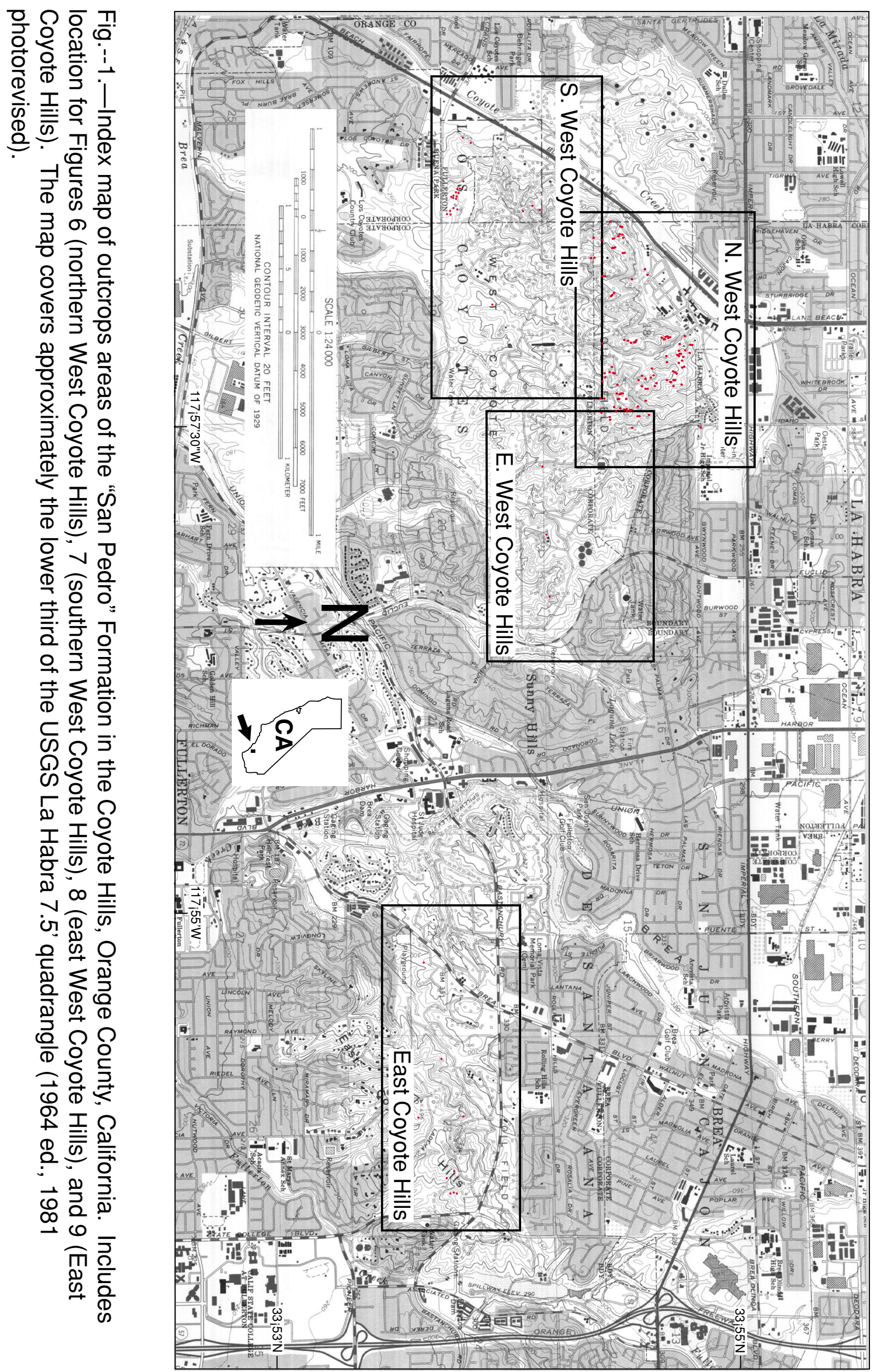

USGS Open-file Report 00-319, page 6 
by Ponti (1989) and Lajoie and others (1991) in the San Pedro area suggest an age range of between $500 \mathrm{ka}$ and $200 \mathrm{ka}$ (middle Pleistocene) for the Lomita Marl, Timms Point Silt, and San Pedro Sands.

Poland and others (1956) redefined the San Pedro Formation in the subsurface as everything between the Pliocene/Pleistocene Pico Formation and unnamed upper Pleistocene sediments. As suggested by Poland and others (1956) this likely includes strata younger than the type San Pedro Sands and strata which is older. Ponti (1989) has shown that the San Pedro Formation in the Torrance Plain includes strata that are significantly older than the type San Pedro Sands. Unfortunately, Poland and others (1956) usage of the name San Pedro Formation has been applied not only to subsurface strata, but also to surface outcrops around the margins of the Los Angeles Basin by later authors. Herein the term San Pedro Sands is used in the sense of Woodring and others (1946) for surfical outcrops in the San Pedro area while the term "San Pedro" Formation (of Poland and others, 1956) is used for all subsurface deposits and surfical outcrops outside of the type area, until this problem can be adequately resolved.

\section{Physical stratigraphy}

West Coyote Hills - Yerkes and others (1965) give a brief description of lower Pleistocene sediments in the Coyote Hills stating that they attaining a thickness of about $100 \mathrm{~m}$ (325 ft) in the West Coyote Hills oil field. Yerkes (1972) referred these strata to the "San Pedro" Formation following Hoskins (1954) and described them as follows "...consists of an upper light-colored sand about $170 \mathrm{ft}(52 \mathrm{~m})$ thick and a lower dark-colored silty sandstone about $155 \mathrm{ft}(47 \mathrm{~m}$ ) thick." Maurer and Conkling (written communication, 1998) report 224 m of "San Pedro" Formation in the western Coyote Hills, but they report fossils from only the upper $120 \mathrm{~m}$. The section they measured is in the bluffs north of Rosecrans Blvd. across from Ralph B. Clark Regional Park headquarters. Near the base, this section is cut by two faults, creating an up-thrown horst. It is unclear if this block belongs to the "San Pedro" Formation or some underlying unit. But a single fossil locality within this part of the section contains Crepidula princeps (Conrad) which restricts the age to late Miocene to middle Pleistocene and is common elsewhere in the "San Pedro" Formation of the Coyote Hills. The sediments are similar to those described by Yerkes (1972) for the lower member of the "San Pedro" Formation in the Coyote Hills, but they could also be attributed to the Fernando Formation as described by Yerkes (1972).

Still observable at Ralph B. Clark Regional Park and described by Yerkes (1972), the upper sand is composed of light gray to pale yellow brown, massive, friable to loose, very coarse grained to pebbly, very poorly sorted, angular grains of quartz, feldspar, and biotite with rust colored clayey matrix and locally abundant mollusks. The upper part of the upper

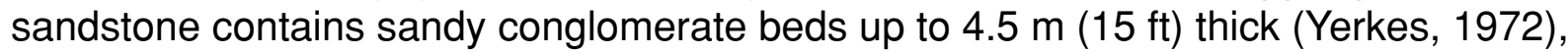
which contains abundant well-rounded flat ellipsoidal pebbles that are somewhat better sorted and more friable than the lower part, and continues into the overlying Coyote Hills Formation.

The lower sandstone is dark yellow gray to olive gray, silty to fine grained, massive, locally well graded or cross laminated sandstone, which contains loadcasts and deformed siltstone clasts in some place (Yerkes, 1972). The upper third is less silty and more friable and contains abundant finely interspersed biotite. The base of this unit is not observable in outcrop, but is characterized in the subsurface as conformable with no lithologic break [W. H. Holman (1959), in lit. in Yerkes (1972)]. Fossils in this unit generally occur in small widely scattered, possibly current accumulated, concentrations and as individual speci- 
mens.

In the northern West Coyote Hills RMW Paleo Associates monitored development (RMW Paleo Associates, 1996a) and made fossil collections. These collections and collections from development of Ralph B. Clark Regional Park were examined during the present study and make up the bulk of the samples studied for the West Coyote Hills. Some, perhaps most, of the specimens collected and studied by Hoskins (1954) were also examined for this study.

A composite stratigraphic section for the northern West Coyote Hills with fossil occurrences is presented in Figure 2. A similar stratigraphic section with fossil occurrences for Ralph C. Clark Regional Park (southern West Coyote Hills) is presented in Figure 3a and $3 b$.

East Coyote Hills - Yerkes (1972) describes the upper part of the "San Pedro" Formation in the East Coyote Hills as only about $14 \mathrm{~m} \mathrm{(45} \mathrm{ft)} \mathrm{thick} \mathrm{with} \mathrm{the} \mathrm{base} \mathrm{not} \mathrm{ex-}$ posed and consisting of light yellow-gray, massive, medium- to coarse-grained, pebbly sandstone that contains a single bed of well-preserved mollusks. Recent grading on the north side of the East Coyote Hills for a golf course and homes showed the "San Pedro" Formation in this area to be up to $20 \mathrm{~m}$ thick and generally composed of massive siltstone underlying interbedded sand and siltstone (D. Stevens, field observations, 1997). RMW Paleo Associates monitored development of this area (RMW Paleo Associates, 1996) and their fossil collections were examined during the present study. No other collections from the East Coyote Hills could not be located. A stratigraphic section for the East Coyote Hills with fossil occurrences is presented in Figure 4.

\section{PREVIOUS PALEONTOLOGICAL STUDIES OF THE “SAN PEDRO” FORMATION IN THE COYOTE HILLS}

Few studies have been done on invertebrate megafossils from the "San Pedro" Formation in the Coyote Hills and the ones that have been done are mainly unpublished [Hoskins (1954); Maurer and Conkling (written communication, 1998)]. Invertebrate megafossils from the Coyote Hills have been mentioned as part of other studies related to the Pleistocene of California (Valentine, 1961), or as part of the general geology of the western Puente Hills (Yerkes, 1972). The occurrence of the "San Pedro" Formation in the Coyote Hills has also been discussed as part of regional studies without mentioning of fossil occurrences [Poland and others (1956), Yerkes and others (1965)]. Studies incorporating invertebrate megafossils from the western Coyote Hills are discussed below.

In a master's thesis, Hoskins (1954) discusses the geology and paleontology of the West Coyote Hills. He recognized two distinct faunas and accompanying rocks that correlate with the two faunas recognized here. His upper formation, "San Pedro Sands(?)," consisted of sands and gravels containing a large, but poorly preserved fauna suggesting shallow water depths and marine conditions possibly warmer than along the adjacent coast today. This unit correlates with the upper, warm water fauna reported here. His lower formation, "Coyote Silt," consists of massively bedded tan to brown silt with occasional sand lenses. Within this unit he reports a cooler, deeper water fauna which correlates with the lower, cool water fauna described below. Both these units are referred to the "San Pedro" Formation here. Hoskins (1954) also reported a brackish water fauna from high in his section with correlates with the fauna reported from the Coyote Hills Formation, below.

Using fauna lists from Hoskins (1954) Valentine (1961) interprets the fauna from the upper part of the "San Pedro" Formation in the western Coyote Hills as dominated by his 


\section{STRATIGRAPHIC SECTION} meters LOCALITIES

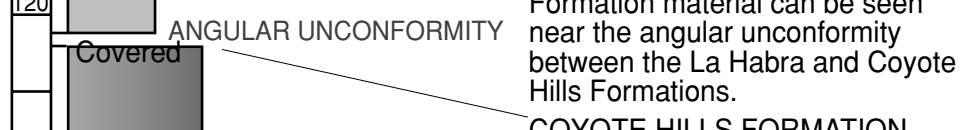

COYOTE HILLS FORMATION

Composed of two basic lithologies, a coarse sand with abundant cobbles and a finer grained mudstone and siltstone unit.

Fine grained mudstone and siltstone containing brackish water mollusks and terrestrial plant fragments
YDNS1118, DNS1146, DNS

1147, EAB051, EAB052, EAB

081, EAB090, JRS1378,JRS

1379, JRS1389, JRS1425,

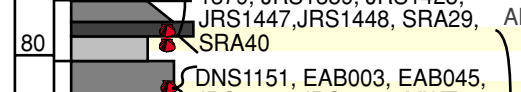

$\left\{\begin{array}{l}\text { DNS1151, EAB003, EAB045, } \\ \text { JRS1399, JRS1400, MWT001, }\end{array}\right.$

DNS1222, EAB053, EAB121,

JRS1429,JRS1430, JRS1434,

MLP148, SRA79,SRA137,

70

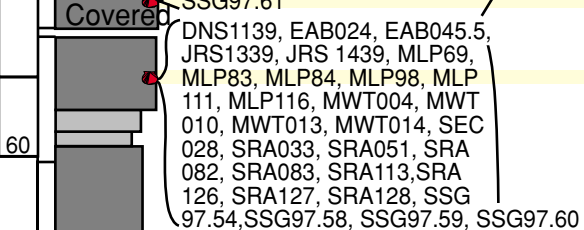

SRA70, SRA132

DNS1206, DNS1219, EAB023,

50 Covered MLP123, MLP103, MLP120

(MWT003, SEC009, SRA118

$40 \quad$ MWT012, РОM35, РОM36

$\{$ DNS1176, DNS1213, MLP60,

$\{$ MLP64

30

30

DNS1181, DNS1207

DPO09, TJM20

TJM33, TJM34, TJM36

DNS1175

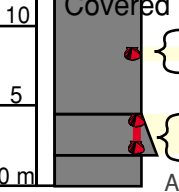

MLP141, SRA120, SRA135

$\{$ SSG98.114, TJM10, TJM29

SDNS1205, MLP140, SRA111, SRA112, SRA121

ANGULAR UNCONFORMITY

\section{NGULAR UNCONFORMITY}

SAN PEDRO FORMTION

Composed of two informally members: an upper coarse sandstone and cobble member and a lower sandstone and siltstone member. Upper member

Lower member

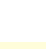

\section{ENVIRONMENTS SUGGESTED BY MOLLUSKS}

\begin{tabular}{|l|}
\hline Legend \\
Conglomerate \\
Sandstone \\
Siltstone \\
Fossiliferous intervals \\
\hline
\end{tabular}

Restricted Environment(?)

Macoma and Tagelus only
(Normal marine conditions; 30-50 m depth. Extinct taxa: Pecten bellus (Conrad); Cancellaria arnoldi (Dall), C. cf. C. tritonidae (Gabb), Crassispira $\mathcal{L}$ zizyphus Berry, Crepidula princeps Conrad

Normal marine conditions; 30-70 m depth. Extinct taxa: Pecten bellus (Conrad), Crepidula princeps Conrad

Normal marine conditions; circa. $50 \mathrm{~m}$ depth, possibly shallower.

Patinopecten caurinus (Gould) suggests slightly cooler than present. Extinct taxa: Pecten bellus (Conrad), Crassispira zizyphus Berry, Crepidula princeps Conrad

Normal marine conditions; circa. $50 \mathrm{~m}$ depth.

Patinopecten caurinus (Gould) suggests slightly cooler than present. Extinct taxa: Cyclocardia cf. C. occidentalis (Conrad), Pecten bellus (Conrad), Cancellaria arnoldi (Dall), Crassispira zizyphus Berry, Crepidula princeps Conrad

$\{$ Normal marine conditions; 0-70 m depth.

$\{$ Extinct taxa: Crepidula princeps Conrad

$\{$ Normal marine conditions; 0-5 m (MLP87), 0-15 m

$\{$ (DNS1219), circa. $50 \mathrm{~m}$ depth for other collections. Pandora wardiana Adams and Patinopecten caurinus (Gould) suggest cooler than present. Extinct taxa: Chlamys opuntia (Dall), Cyclocardia cf. C. occidentalis (Conrad), Pecten bellus (Conrad), Crepidula princeps Con.

Normal marine conditions; 25-50 m depth.

Extinct taxa: Pecten bellus (Conrad)

Normal marine conditions; 30-114 m depth. Patinopecten caurinus (Gould) suggests slightly cooler than present. Extinct taxa: Cyclocardia cf. C. occidentalis (Conrad), Pecten bellus (Conrad), Crepidula princeps Con.

Normal marine conditions; 10-200 m depth.

$\left\{\begin{array}{l}\text { Normal marine conditions; } 10-200 \mathrm{~m} \text { depth. } \\ \text { Patinopecten caurinus (Gould) suggests slightly }\end{array}\right.$

cooler than present.

Normal marine conditions

Normal marine conditions; $20-50$ m depth. Patinopecten caurinus (Gould) suggests slightly cooler than present.

Normal marine conditions

Normal marine conditions

$\left\{\begin{array}{l}\text { Normal marine conditions. } \\ \text { Patinopecten caurinus (Gould) suggests slightly }\end{array}\right.$ cooler than present.

Normal marine conditions; circa. $50 \mathrm{~m}$ depth. Macoma cf. M. moesta Carpenter, Pandora wardiana Adams, and Patinopecten caurinus (Gould) suggests slightly cooler than present.

Fig. 2.-Composite stratigraphic section for the northern West Coyote Hills with fossil localities and environmental interpretations. 


\section{STRATIGRAPHIC} SECTION

FOSSIL LOCALITIES

\section{ROCK-STRATIGRPAHIC} UNITS

COYOTE HILLS FORMATION

Composed of two basic lithologies, a coarse sand with abundant cobbles and a finer grained mudstone and siltstone unit.

\section{SAN PEDRO FORMTION}

Composed an upper coarse sandstone to fine sandstone member over a lowersiltstone member which could represent the underlying formation.

\section{ENVIRONMENTS SUGGESTED BY MOLLUSKS}

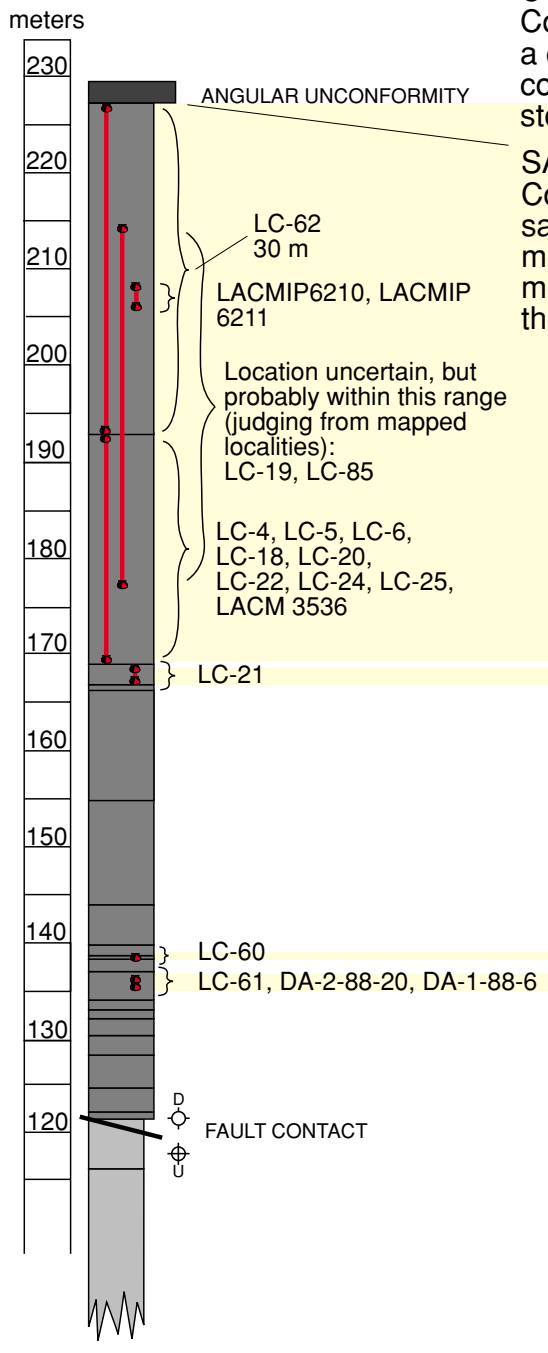

Normal marine conditions; 2-150 m depth.

Normal marine conditions; probably between 30-60 m.

Several taxa suggest slightly warmer than present temperatures Extinct taxon: Pecten bellus (Conrad).

Normal marine conditions; shelfal water depths. Patinopecten caurinus (Gould) suggests slightly cooler than present.

Normal marine conditions: 50-60 m depth Patinopecten caurinus (Gould) suggests slightly cooler than present. Extinct taxa: Crepidula princeps Conrad, Dendraster venturaensis Kew.

Normal marine conditions; circa. $50 \mathrm{~m}$ depth, possibly shallower.

Patinopecten caurinus (Gould) suggests slightly cooler than present. Extinct taxa: Pecten bellus (Conrad), Crepidula cf.

C. princeps Conrad, Dendraster venturaensis Kew.

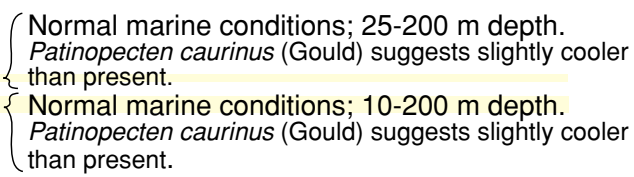

\begin{tabular}{|l|}
\hline Legend \\
\hline Conglomerate \\
Sandstone \\
Siltstone \\
Fossiliferous intervals \\
\hline
\end{tabular}

Fig. 3a.-Composite stratigraphic section of approximately the top half (some overlap) for the Ralph C. Clark Regional Park (southern West Coyote Hills) with rock stratigraphic units, fossil localities, and environmental interpretations from mollusks.

Tellina bodegensis Hinds - Forreria belcheri (Hinds) association with mixed Lucinoma annulata (Reeve) - Turcica caffea Gabb and Thyasira flexuosa (Montagu) [=T. gouldii (Philippi)] - Neptunea tabulata (Baird) community assemblages as minor constituents. Assemblages suggesting deeper-water depths (Lucinoma annulata Reeve-Turcica caffea Gabb and Thyasira flexuosa (Montagu) -Neptunea tabulata Baird assemblages) and cold water element of Valentine's (1961) Oregonian element are present in the underlying silt. These underlying silts yield a smaller assemblage with larger percentages of northern forms. Valentine (1961) suggests that the fauna from the "San Pedro" Formation in the Coyote Hills resembles assemblages from the Pico and Saugus Formations in the Ventura Basin. 
STRATIGRAPHIC SECTION

FOSSIL LOCALITIES

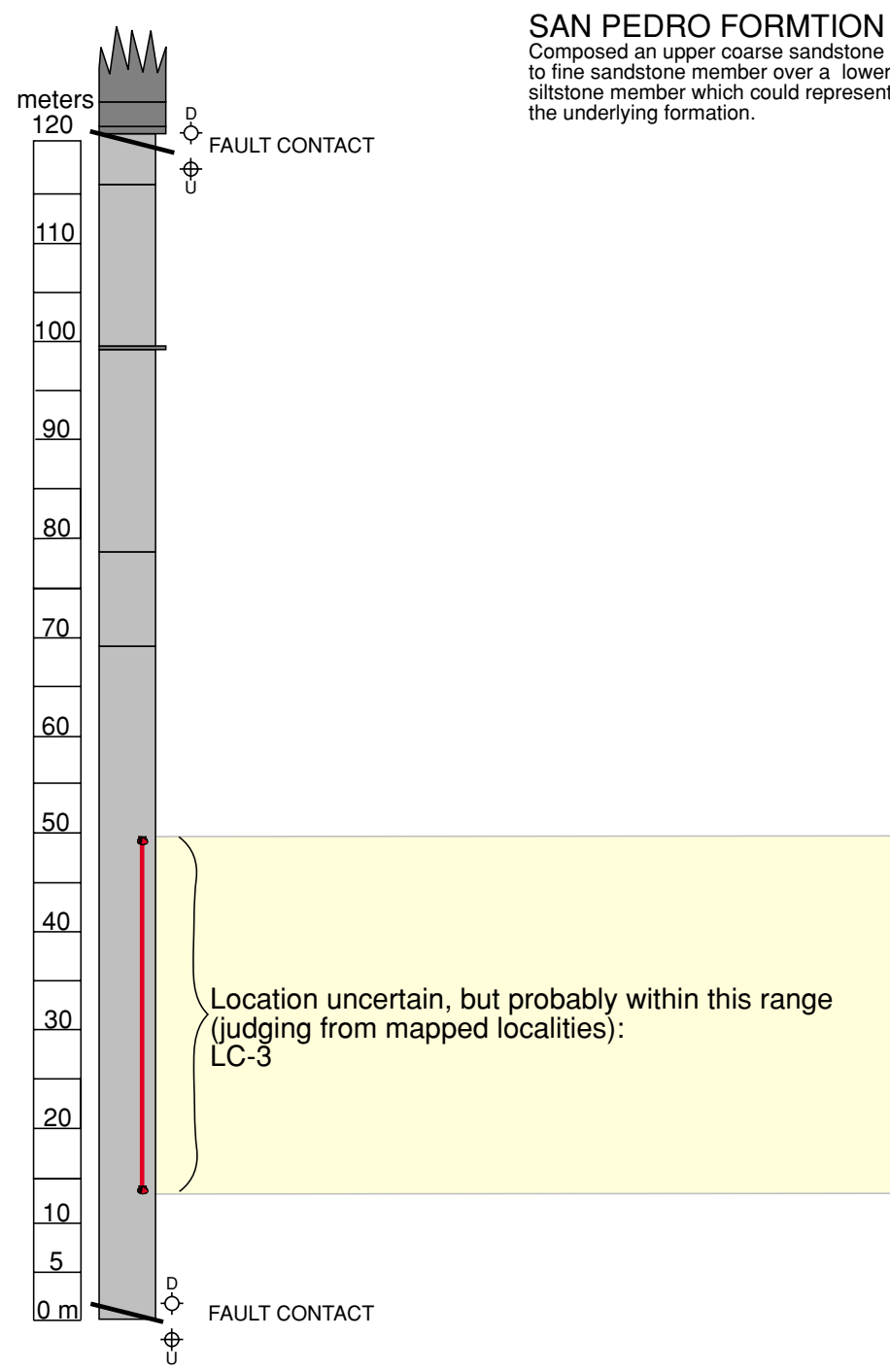

ROCK-STRATIGRPAHIC UNITS

SAN PEDRO FORMTION Composed an upper coarse sandstone to fine sandstone member over a lower siltstone member which cou
the underlying formation.
ENVIRONMENTS SUGGESTED BY MOLLUSKS

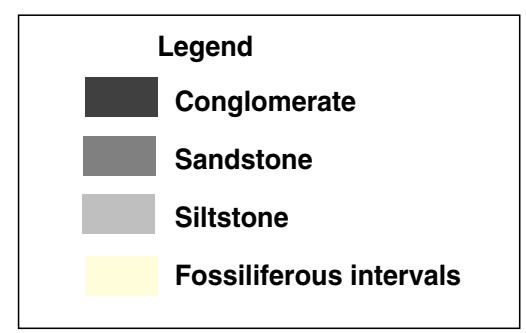

Normal marine conditions; 25-200 m depth. Patinopecten caurinus (Gould) suggests slightly cooler than present. Extinct taxon: Crepidula princeps (Conrad)

Fig. 3b.-Composite stratigraphic section of approximately the bottom half (some overlap) for the Ralph C. Clark Regional Park (southern West Coyote Hills) with rock stratigraphic units, fossil localities, and environmental interpretations from mollusks.

Yerkes (1972) cites the "San Pedro" Formation in the West Coyote Hills as attaining

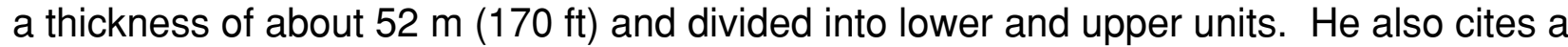
fauna of 115 mollusks, (60 bivalves, 53 gastropods, two scaphopods), two echinoids, and one arthropod. The lower sandstone contains scattered mollusks, while the upper sandstone contains locally abundant mollusks.

A unpublished manuscript on the paleoecology of the "San Pedro" Formation at Ralph B. Clark Regional Park by Maurer and Conkling (MS) reports a fauna of 82 invertebrates (66 mollusks) and 13 vertebrates taxa. They interpret the fauna as occurring on a shallow, protected bottom (approximately $10 \mathrm{~m}$ ), which deepens, down section, to shallow continental shelf depths (50-100 m). Some of their samples are at the Interpretative Center, Ralph B. Clark Regional Park and were used in this present study. Significant in this report is a strontium isotope age determination of $1.4 \pm 0.4 \mathrm{Ma}$ from a Patinopecten caurinus 
STRATIGRAPHIC

SECTION

FOSSIL

LOCALITIES
ROCK-STRATIGRPAHIC UNITS
ENVIRONMENTS SUGGESTED BY MOLLUSKS

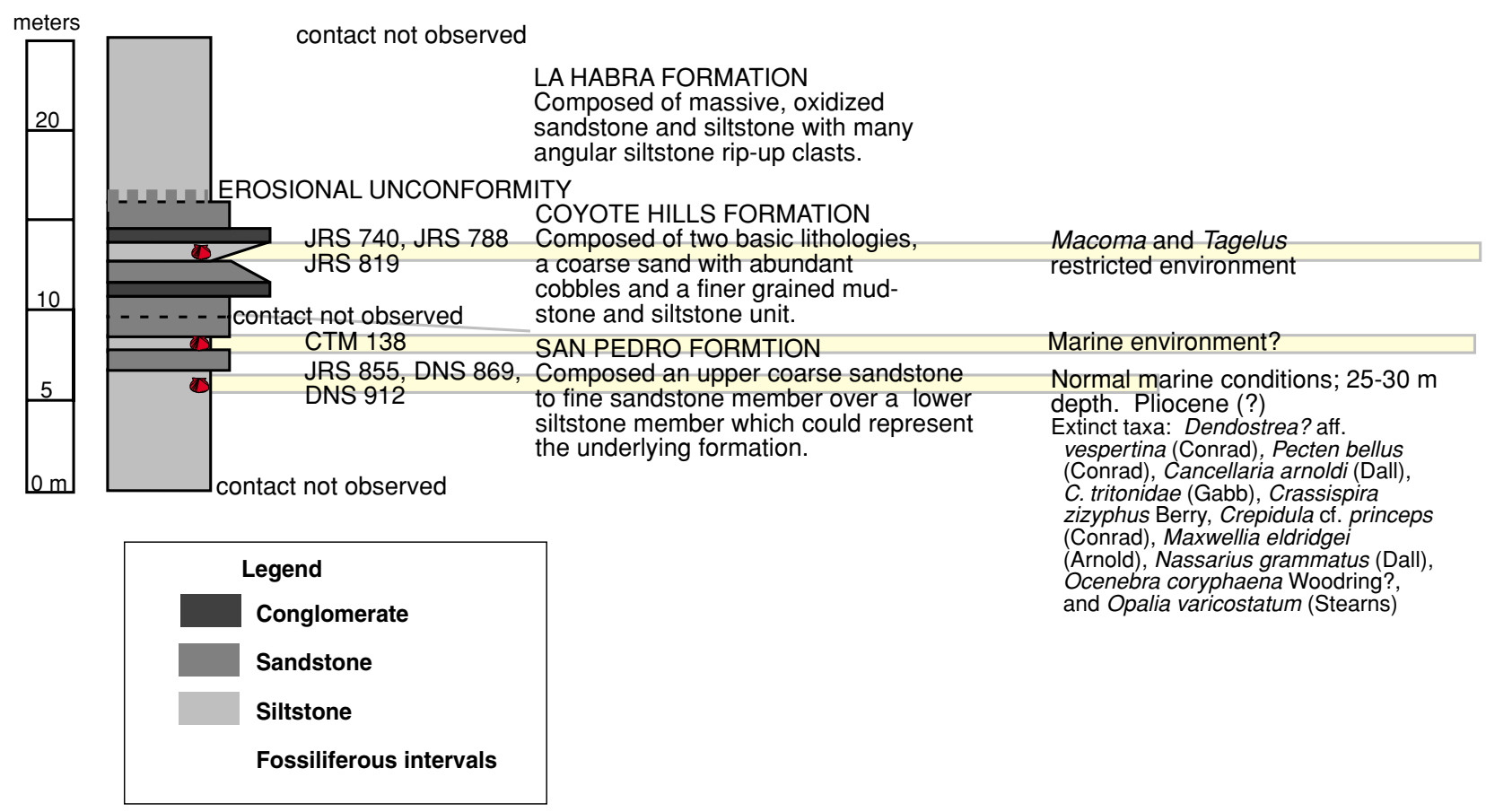

Fig. 4.-Composite stratigraphic section for the East Coyote Hills with rock stratigraphic units, fossil localities, and environmental interpretations from mollusks.

(Gould) (RBCRP LC-60) collected from the lower fauna in the upper part of the "San Pedro" Formation exposed north of Rosecrans Blvd. in the Park.

Welton (written communication, 1998) discuss the paleoecology of a small ichthyofauna from the "San Pedro" Formation west of Ralph B. Clark Regional Park and now buried under a housing track (LACMIP 6210 [=LACMVP 5011], LACMIP 6211 [=LACMVP 5012]) and collected during paleontological monitoring (Weir and Morgan, 1982). They report a fauna of nine elasmobranchs and fourteen teleosts, which are all extant and found today along the adjacent Los Angeles County coast at depths between 15 and $60 \mathrm{~m}$. Associated with the vertebrates is an invertebrate fauna of 55 taxa (52 mollusks, 1 bryozoan, and 2 echinoids) identified by Edward C. Wilson and Phillip G. Owen (both formerly of the LACMIP). The invertebrate part of these collections have also been re-examined during the course of the present study. Welton and others (MS) suggest that although the "San Pedro" Formation is ecologically equivalent to the type San Pedro Sands in San Pedro, it is older.

Recent work by Powell and Stevens (1999; in press) present preliminary results from this study, which are fully documented here.

\section{FAUNAL COMPOSITION AND PALEOECOLOGY}

Faunal composition and preservation - The fauna from the "San Pedro" Formation in the Coyote Hills (from 158 localities) consists of 181 taxa; 1\% (two) annelids, 96\% (174) mollusks [44\% (80) bivalves, 52\% (94) gastropods, 2\% (three) scaphopods), 3\% 
(five) arthropods, and 2\% (three) echinoids, and is presented in Table 1. Preservation is variable between beds, but is generally very good to excellent. A correlation chart between the northern West Coyote Hills, southern West Coyote Hills (Ralph B. Clark Regional Park), and the East Coyote Hills is presented in Figure 5.

Table 1.-Molluscan taxa reported from the "San Pedro" Formation in the Coyote Hills, Orange County, southern California. Occurrences of taxa in the various faunas are shown. Taxa not marked with an "x" could not be referred to a specific fauna with confidence. Taxa with their names underlined have been reported from the Coyote Hills, but were not recognized during the present study and their occurrence in the "San Pedro" Formation in the Coyote Hills needs confirmation.

TAXA/OCCURRENCE

ANNELIDA

POLYCHAETA

Cirratulidae, indeterminate

Serpulidae, indeterminate

MOLLUSCA

BIVALVIA

Amiantis callosa (Conrad, 1837)

Argopecten ventricosus (Sowerby, 1842)

Cardiidae, indeterminate

Chione californiensis (Broderip in Broderip \& Sowerby, 1835)

Chione undatella (Sowerby, 1835)

Chlmays sp., cf. C. anapleus Woodring, 1946

Chlamys beringiana (Middendorff, 1849)

Chlamys hastata (Sowerby, 1843)

Chlamys opuntia (Dall, 1898)

Chlamys rubida (Hinds, 1845)

Chlamys sp.

Clinocardium sp.

Compsonyax subdiaphana (Carpenter, 1864)

Crassadoma giganteus (Gray, 1825)

Crassinella? sp.

Cryptomya californica (Conrad, 1837)

Cyathodonta pedroana Dall, 1915

Cyclocardia sp., aff. C. occidentalis (Conrad, 1855)

Dendostrea? vespertina (Conrad, 1854)

Diplodonta orbellus (Gould, 1851)

Donax californicus Conrad, 1837

Donax gouldii Dall, 1921

Epilucina californica (Conrad, 1837)

Gari fucata (Hinds, 1845)

Glycymeris septentrionalis (Middendorff, 1849)

Humilaria kennerleyi (Reeve, 1863)

Larkinia camuloensis (Osmont, 1905)

Leporimetis obesa (Deshayes, 1855)

Leptopecten latiauratus (Conrad, 1837)

Lithophaginae, indeterminate

Lucinisca nuttalli (Conrad, 1837)

Lucinoma annulata (Reeve, 1850)

Lucinidae, indeterminate

Lyropecten cerrosensis (Gabb. 1866)

Macoma indentata Carpenter, 1864

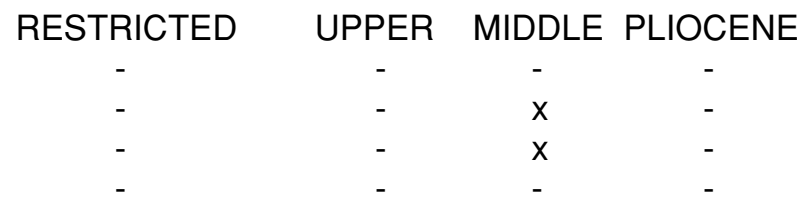


TAXA/OCCURRENCE

Macoma sp., cf. M. modesta Carpenter, 1864

Macoma nasuta (Conrad, 1837)

Macoma secta (Conrad, 1837)

Macoma sp.

Macromeris catiliformis (Conrad, 1867)

Mactromeris hemphilli (Dall, 1894)

Mactrotoma californica (Conrad, 1837)

Miodontiscus prolongatus (Carpenter, 1864)

Modiolus rectus (Conrad, 1837)

Mytilus californianus Conrad, 1837

Mytilus coalingensis Arnold, 1909

Mytilus trossulus Gould, 1850

Nuculana taphria (Dall, 1896)

Nuculana sp.

Nutricola lordi (Baird, 1863)

Nutricola tantilla (Gould, 1853)

Ostrea conchapila Carpenter, 1857

Pandora wardiana Adams, 1860

Pandora sp.

Panopea abrupta (Conrad, 1849)

Parvilucina tenuisculpta (Carpenter, 1864)

Patinopecten caruinus (Gould, 1850)

Pecten bellus Conrad, 1857

Pectinidae, indeterminate

Periploma planiusculum Sowerby, 1834

Pododesmus macrochisma (Deshayes, 1839)

Protothaca tenerrima (Carpenter in Gould \& Carpenter, 1857) -

Protothaca sp.

Saxidomus nuttalli Conrad, 1837

Semele pulchra (Sowerby, 1832)

Semele venusta (Reeve, 1853)

Semele? sp.

Siliqua sp.

Solamen sp., cf. S. columbianum (Dall, 1879)

Solen sp., cf. S. sicarius Gould, 1850

Spisula sp.

Tagelus sp., cf. T. californianus (Conrad, 1837)

Tagelus sp., cf. T. subteres (Conrad, 1837)

Tellina bodegensis Hinds, 1845

Tellina sp., cf. T. moesta (Carpenter, 1864)

Tellinidae, indeterminate

Teredinidae, indeterminate

Thracia trapezoides Conrad, 1849

Tivela stultorum (Mawe, 1823)

Trachycardium panamense (Sowerby, 1833)

Trachycardium quadragenarium (Conrad, 1837)

Tresus nuttalli (Conrad, 1837)

Veneridae, indeterminate

GASTROPODA

Acanthina spirata (Blainville, 1832)

Acteocina culcitella (Gould, 1853)

Acteocina harpa (Dall, 1871)

Acteon sp.

Alia carinata (Hinds, 1844)

Amphissa reticulata Dall, 1916

Astrea gibberosa (Dillwyn, 1817)

Astrea undosa (Wood, 1828)

Astyris gausapata (Gould, 1850)

RESTRICTED UPPER MIDDLE PLIOCENE

\begin{tabular}{|c|c|c|c|}
\hline- & - & $x$ & - \\
\hline - & - & - & - \\
\hline- & $x$ & - & - \\
\hline$x$ & - & - & - \\
\hline - & $x$ & - & - \\
\hline - & $x$ & - & - \\
\hline - & $x$ & - & - \\
\hline - & - & - & - \\
\hline - & $x$ & - & - \\
\hline - & - & - & - \\
\hline- & - & - & - \\
\hline- & - & $x$ & - \\
\hline - & $x$ & $x$ & $x$ \\
\hline - & - & - & - \\
\hline - & - & - & - \\
\hline - & - & - & - \\
\hline - & $x$ & - & - \\
\hline - & - & $x$ & - \\
\hline - & $x$ & $x$ & - \\
\hline - & $x$ & $x$ & $x$ \\
\hline - & $x$ & - & - \\
\hline- & - & $x$ & - \\
\hline - & $x$ & $x$ & $x$ \\
\hline - & - & - & - \\
\hline - & $x$ & - & - \\
\hline - & $x$ & $x$ & - \\
\hline - & $x$ & - & - \\
\hline- & - & - & - \\
\hline - & $x$ & $x$ & - \\
\hline- & - & - & - \\
\hline - & - & - & - \\
\hline- & - & - & - \\
\hline - & - & - & - \\
\hline - & - & $x$ & - \\
\hline - & - & $x$ & - \\
\hline- & - & $x$ & $?$ \\
\hline- & - & - & - \\
\hline$x$ & - & - & - \\
\hline - & - & - & - \\
\hline - & - & - & - \\
\hline- & - & - & - \\
\hline- & - & - & - \\
\hline- & - & $x$ & - \\
\hline - & $x$ & - & - \\
\hline- & $x$ & - & - \\
\hline - & $x$ & $x$ & - \\
\hline- & $x$ & cf. & ? sp \\
\hline
\end{tabular}

$\begin{array}{lll}x & - & - \\ - & - & - \\ - & - & - \\ x & - & - \\ - & - & x \\ - & - & - \\ x & x & - \\ x & - & x \\ - & x & -\end{array}$ 
TAXA/OCCURRENCE

Boreotrophon sp., cf. B. multicostatus (Eschscholtz, 1829)

Boreotrophon pedroana (Arnold, 1903)

Bulla gouldiana Pilsbry in Tryon, 1895

Bursa californica (Hinds, 1843)

Calicantharus fortis (Carpenter, 1866)

Calliostoma annulatum (Lightfoot, 1786)

Calliostoma canaliculatum (Lightfoot, 1786)

Calliostoma gemmulatum Carpenter, 1864

Calliostoma ligatum (Gould, 1849)

Calliostoma variegatum Carpenter, 1864

Calliostoma sp.

Calyptraea spirata (Forbes, 1852)

Cancellaria arnoldi (Dall, 1909)

Cancellaria fergusoni Carson, 1926

Cancellaria tritonidae (Gabb, 1866)

Clathromangelia variegata (Carpenter, 1864)

Clathurella sp.

Conus californicus Reeve, 1844

Crassispira semiinflata (Grant and Gale, 1931)

Crassispira zizyphus Berry, 1940

Crepidula adunca Sowerby, 1825

Crepidula onyx Sowerby, 1824

Crepidula princeps (Conrad, 1856)

Crockerella conradiana (Gabb, 1869)

Crucibulum spinosum (Sowerby, 1824)

Cryptonatica affinis (Gmelin, 1791)

Cylichna attonsa (Carpenter, 1864)

Cypraea spadicea Swainson, 1823

Cymatosyrix hemphilli (Stearns, 1871)

Epitonium bellastriata (Carpenter, 1864)

Epitonium indianorum (Carpenter, 1864)

Epitonium sawinae (Dall, 1903)

Erato vitellina Hinds, 1844

Fusinus sp., cf. F. arnoldi Cossman, 1903

Fusinus barbarensis (Trask, 1855)

Haliotis cracherodii Leach, 1814

Halistylus pupoideus (Carpenter, 1864)

Haminoea vesicula (Gould, 1855)

Homalopoma paucicostatum (Dall, 1871)

Kelletia kelletii (Forbes, 1852)

Lacuna unifasciata Carpenter, 1857

Lirobittium lomaensis (Bartsch, 1911)

Lirobittium rugatum (Carpenter, 1864)

Littorina scutulata Gould, 1849

Maxwellia eldridgei (Arnold, 1907)

Megasurcula carpenteriana (Gabb, 1865)

Mitra idea Melville, 1893

Mitrella sp.

Nassarius sp., cf. N. cerritensis (Arnold, 1903)

Nassarius fossatus (Gould, 1849)

Nassarius sp., cf. N. grammatus (Dall, 1917)

Nassarius insculpta (Carpenter, 1864)

Nassarius mendicus (Gould, 1849)

Nassarius perpinguis (Hinds, 1844)

Nassarius tegula (Reeve, 1853)

Naticidae, indeterminate

Neptunea tabulata (Baird, 1863)

Neverita reclusiana (Deshayes, 1839)
RESTRICTED

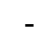

UPPER MIDDLE PLIOCENE

$\begin{array}{lll}- & \mathrm{x} & - \\ - & \mathrm{x} & - \\ - & - & \mathrm{x} \\ \mathrm{x} & - & - \\ \mathrm{x} & - & \mathrm{sp} . \\ \mathrm{x} & - & - \\ \mathrm{cf} . & - & - \\ - & - & \mathrm{x} \\ - & - & \mathrm{cf} \\ - & - & - \\ - & - & \mathrm{x} \\ - & \mathrm{sp} . & - \\ - & - & \mathrm{x} \\ \mathrm{x} & - & \mathrm{sp} . \\ - & - & \mathrm{x} \\ - & - & - \\ - & - & - \\ \mathrm{x} & \mathrm{cf} . & \mathrm{x} \\ - & - & \mathrm{x} \\ \mathrm{x} & \mathrm{x} & \mathrm{x} \\ \mathrm{x} & - & \mathrm{sp} .\end{array}$

cf.

cf.

-

$-$

$-$

$x$

sp.

$-$

sp.

sp.

$-$

$-$

$\mathrm{X}$

sp.

sp. $\quad \mathrm{sp}$

sp.

$x$

$x$

$-$

$\bar{x}$

$\mathrm{x}$

-

cf.

$$
x
$$

$$
\mathrm{x}
$$$$
\begin{aligned}
& x \\
& x \\
& x
\end{aligned}
$$ 
TAXA/OCCURRENCE

RESTRICTED UPPER MIDDLE PLIOCENE

Nucella lamellosa (Gmelin, 1791)

Ocenebra coryphaena Woodring in Woodring and others,

1946

Ocenebra foveolata (Hinds, 1844)

Olivella baetica Carpenter, 1864

Olivella biplicata (Sowerby, 1825)

Olivella sp.

Opalia borealis Keep, 1881

Opalia sp., cf. O. varicostatum (Stearns, 1875)

Ophiodermella mercedensis (Martin, 1914)

Ophiodermella inermis (Reeve, 1843)

Polinices draconis (Dall, 1903)

Polinices lewisii (Gould, 1847)

Polygireulima rutila (Carpenter, 1864)

Pseudomelatoma sp., cf. P. pencillata (Carpenter, 1864)

Scabrotrophon sp., cf. S. lasius Dall, 1919

Seila montereyensis Bartsch, 1907

Sinum scopulosum (Conrad, 1849)

Tegula sp., cf. T. funebralis (Adams, 1855)

Tegula pulligo (Gmelin, 1791)

Terebra danai Berry, 1958

Turbonilla sp.

Turridae, indeterminate

Turritella cooperi Carpenter, 1864

Volvarina? sp.

Volvulella cylindrica (Carpenter, 1864)

SCAPHOPODA

Dentalium neohexagomun Sharp and Pilsbry, 1897

Dentalium pretiosum Sowerby, 1860

Dentalium sp.

ARTHROPODA

CRUSTACEA

Balanus? sp. (barnacle)

Cancer sp. (crab)

Coronula? sp. (whale barnacle)

Randallia ornata (Randell, 1839)

Indeterminate crab fragments

ECHINODERMATA

ECHINOIDEA

Clypeasteriod, indeterminate

Dendraster venturaensis Kew, 1920

Indeterminate echinoid spines

In comparison, a fauna reported by Groves (1991) from the Pliocene - Pleistocene Saugus Formation appears to have been deposited in a similar environment and during the same period of time (near the Pliocene - Pleistocene boundary), but from considerably fewer localities (15). It contains 100 significant taxa of which 5\% (five) are brachiopods, $92 \%$ (92) mollusks [43\% (43) bivalves, $49 \%$ (49) gastropods, $1 \%$ (one) scaphopod], $2 \%$ (two) barnacles, and 1\% (one) echinoid. These percentages compare favorably with those from the "San Pedro" Formation in the Coyote Hills with $90+\%$ of the Coyote Hills fauna composed of mollusks, somewhat equally divided between bivalves and gastropods, with annelids, scaphopods, arthropods, and echinoderms as minor constituents.

Paleoecology - An ecologically restricted (marginally marine) fauna is found in the Coyote Hills Formation above all the other fauna and is represented by several collections. Two distinct faunules are recognized in the upper member of the "San Pedro" Formation of 


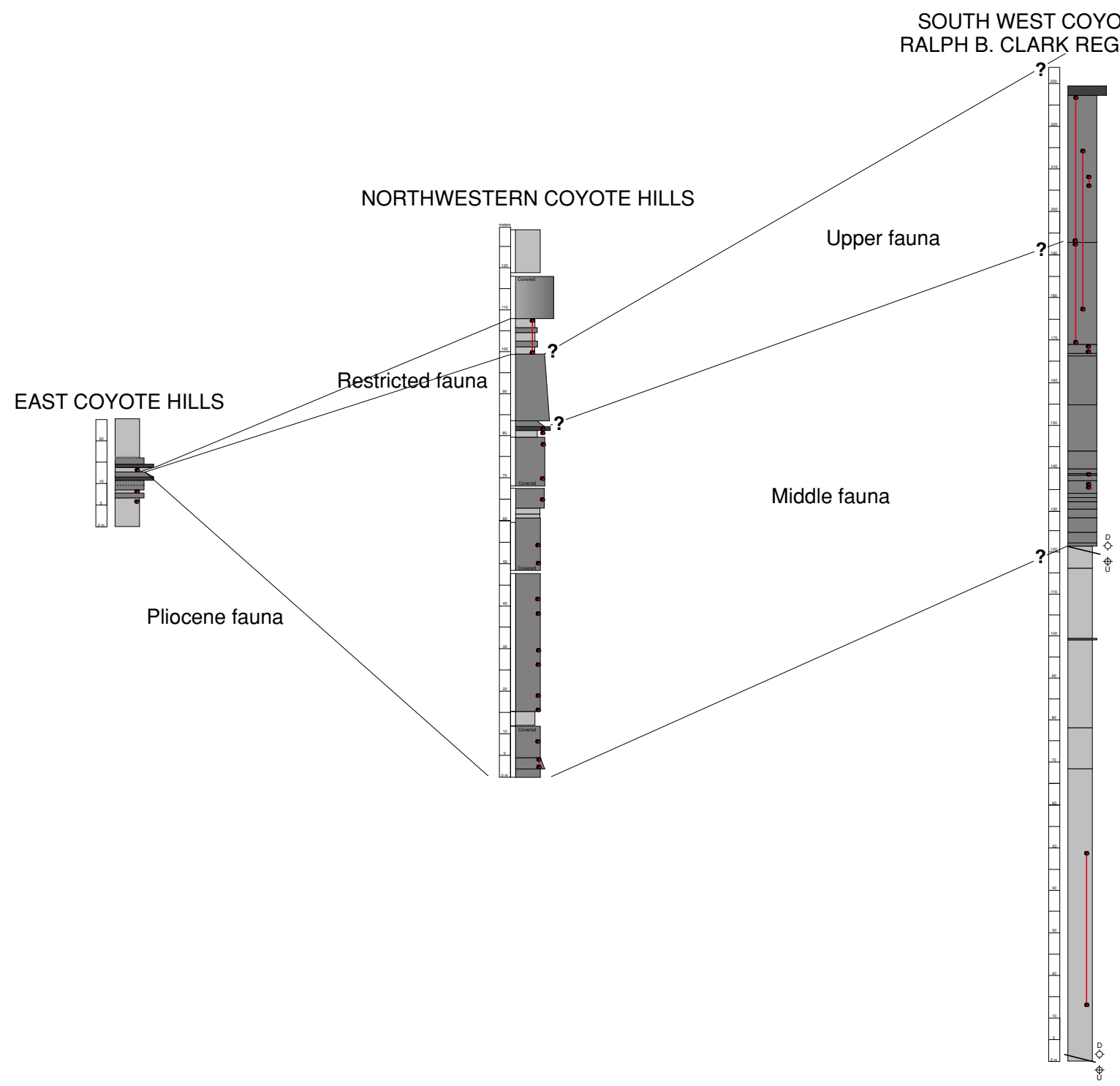

Fig. 5.-Correlation chart of stratigraphic sections in the northern West Coyote Hills, southern West Coyote Hills (Ralph C. Clark Regional Park), and East Coyote Hills. See individual stratigraphic section for details. From youngest to oldest the faunas are 1) the restricted fauna, which is exposed in the East Coyote Hills and northern West Coyote Hills; 2) the upper "warm water" fauna which is only recognized in the southern West Coyote Hills; 3 ) the middle "cool water" fauna which is recognized in the northern and southern West Coyote Hills; and 4) the lower "Pliocene" fauna which is known with certainty from only one site in the East Coyote Hills.

Yerkes (1972) from collections at LACMIP, RBCRP and RMW Paleo Associates. The upper fauna is recognized only from a few collections from Ralph Clark Regional Park and west of the Park, and possibly in the northern West Coyote Hills. The lower fauna occurs widely in the "San Pedro" Formation in the Coyote Hills and extends from the upper member down into the lower member of Yerkes (1972). Exact stratigraphic data for some collections is imprecise or lacking, but the collections generally show a shallow, warmer water taxa overlying a deeper, cool water fauna, followed by a Pliocene fauna. The latter is questionably separated from the cool water fauna and is recognized only from a single collection in 
the East Coyote Hills.

Restricted fauna.- - In the Coyote Hills, an unusual marine fauna exists in the Coyote Hills Formation, overlying the "San Pedro" Formation. It only contains the bivalve mollusks Tagelus sp., cf. T. subteres (Conrad), indeterminate Macoma, and unidentified bivalve fragments. Hoskins (1954) and Yerkes (1972) also report plant remains and the bivalve mollusk Cryptomya californica (Conrad) from the Coyote Hills Formation, but it has not been recognized in collections examined. This fauna occurs in highly fractured, fine grays, siltstone to mudstone, and is found in isolated blocks (D. Stevens, pers. comm., 1998). It is underlain by wood which has been radiocarbon dated at $>40,000$ ka (Shinn, 1999). Because this age is nearly at the limit of radiocarbon dating, it suggests a minimum age for this fauna (> 40,000 ka). The few taxa present in this fauna suggest a restricted marine environment and are dissimilar to anything encountered in the "San Pedro" Formation in the Coyote Hills. Based on its stratigraphic position, this is the youngest marine fauna occurring in the Coyote Hills, but an accurate age for these collections has not been determined.

Upper fauna.-Molluscan taxa from this fauna, referred to as the warm-water fauna, suggests temperatures similar to those occurring off the Los Angeles/Orange County coast today, or slightly warmer as suggested by two extra-limital southern taxa: Argopecten ventricosus (Sowerby) and Trachycardium panamense (Sowerby). These taxa do not occur today north of about $32^{\circ} \mathrm{N}$ (northern Baja California, Mexico). This fauna also contains several mollusks, which do not occur today north of the latitude of the fossil locality (circa. 34 $\mathrm{N}$ ) [data from Bernard (1983) for the bivalves and McLean (1978) for the gastropod]. These taxa include the bivalves Chione californiensis (Broderip in Broderip \& Sowerby), Chione undatella (Sowerby), Donax californicus Conrad, Gari fucata (Hinds), Leporimetis obesa (Deshayes), and the gastropod Terebra pedroana Dall. This fauna represents Valentine's (1961) Tellina bodegensis Hinds - Forreria belcheri (Hinds) community and suggests shallow inner sublittoral water depths (about 9 to $20 \mathrm{~m}$ ). This fauna has been recognized only in a few collections from the West Coyote Hills (LACMIP 477, LACMIP 6010, questionably RMW/JRS1379, and PC264).

Middle fauna.-Stratigraphically below the warm water fauna in the upper to lower members of the "San Pedro" Formation is a cool water fauna with northern extra-limital taxa that do not exist along the Orange County/Los Angeles County coast today. It is characterized by the occurrence of the bivalves Lucinoma annulata (Reeve), Panope abrupta (Conrad), Patinopecten caurinus (Gould), and/or the gastropods Crepidula princeps (Conrad) and Neptunea tabulata (Baird). Other cool water extra-limital taxa which are also associated with the fauna include the bivalve Pandora wardiana Adams, and the gastropod Boreotrophon sp., cf. B. multicostatus (Eschscholtz). Reconstruction of the depth of deposition of faunas containing Patinopecten caurinus (Gould) suggests water depths greater than $20 \mathrm{~m}$ and probably less than $60 \mathrm{~m}$, although many collections are not well constrained. This fauna represents mixed Lucinoma annulata (Reeve) - Turcica caffea Gabb and Thyasira flexuosa (Montagu) [=T. gouldii (Philippi)] - Neptunea tabulata (Baird) communities of Valentine (1961) and is supplemented by some of his cold water Oregonian elements. In the Ralph Clark Regional Park section it is possible that this fauna both underlies and overlies the "warm-water fauna." This is based on collections containing the cold water taxon Patinopecten caurinus (Gould) which possibly overlie LACMIP 6210, a sample containing taxa which could represent water temperatures similar to those present along the 
adjacent coastline. But the collections containing P. caurinus (Gould) are poorly located stratigraphically and could entirely underlie the upper, "warm water, fauna." This said, I think it likely that the "warm-water fauna" completely overlies the "cool-water fauna."

Pliocene fauna.-A single collection (RMW/JRS 855) in the East Coyote Hills contains several extinct mollusks which suggest a Pliocene age. Ecologically, the fauna suggests water temperatures similar to off the adjacent Orange County coast today at water depths between $25 \mathrm{~m}$ and $30 \mathrm{~m}$, but otherwise does not look different than the cool water fauna above.

\section{AGE}

The following definitions are used here: late Pleistocene, approximately 140 ka to $12 \mathrm{ka}$; middle Pleistocene, approximately 720 ka to $140 \mathrm{ka}$; early Pleistocene, the Pliocene/ Pleistocene boundary at about $1.8 \mathrm{Ma}$ to about $720 \mathrm{ka}$.

\section{Paleontologic Age}

Restricted fauna.-This fauna contains no age significant taxa. Based on stratigraphic position alone it is probably middle Pleistocene or younger in age. Future aminoacid studies should help resolve this problem.

Upper fauna.-Extinct taxa and their ranges are presented in Table 2. The questionable identification of Chlamys anapleus Woodring at PC264, which has previously been reported only from the Lomita Marl and San Pedro Sands in the San Pedro area, Los Angeles County (Woodring and others, 1946), suggests a middle Pleistocene age. The occurrence of Pecten bellus (Conrad) at LACMIP 6211 argues for a late Pliocene to early Pleistocene age for this fauna. Mytilus coalingensis Arnold, Crepidula princeps Conrad and Chione sp. are questionably identified in the associated collection (PC 265). If the identifications of Mytilus coalingensis Arnold and Crepidula princeps Conrad prove correct and they are part of the warm water fauna, then their presence suggests, either 1) a early to middle Pleistocene age for the upper fauna, 2) a stratigraphic range extension to early Pleistocene for $C$. anapleus Woodring, or 3 ) a stratigraphic range extension to middle Pleistocene for $P$. bellus (Conrad). I would favor case 1 above as there is no other evidence for extending the stratigraphic range of either taxa at this time.

Table 2.-Stratigraphic ranges of extinct taxa recovered from the upper, warm water, fauna in the West Coyote Hills, Orange County, California.

TAXA/AGE

Mollusca

Bivalvia

Chlamys anapleus Woodring

Mytilus coalingensis Arnold

Pecten bellus (Conrad)

Gastropoda

Calicantharus fortis (Carpenter

Cancellaria fergusoni Carson

Crassispira zizyphus Berry

Crepidula princeps Conrad

$\begin{array}{cccc}\text { late } & \text { early } & \text { late } & \text { early } \\ \text { Miocene } & \text { Pliocene } & \text { Pliocene } & \text { Pleistocene }\end{array}$

X

$-\quad X$

$X \quad X$

$X \quad X$

?

$\mathrm{X}$

$\begin{array}{llll}X & X & X & X \\ - & - & X & X \\ - & - & X & X \\ X & X & X & X\end{array}$


Middle fauna.-Seven extinct taxa are recorded here from the middle fauna in the "San Pedro" Formation in the Coyote Hills (Table 3). The age ranges of some of these taxa has changed over recent years as have the ages of the formations which contain them (see Appendix 1 for a complete stratigraphic discussion). Taken together extinct taxa from this fauna suggest an age of late Pliocene to early Pleistocene for the "San Pedro" Formation in the Coyote Hills.

Table 3.-Stratigraphic ranges of extinct taxa from the middle, cool water, fauna in the Coyote Hills, Orange County, California.

TAXA/AGE

Mollusca

Bivalvia

Chlamys opuntia (Dall)

Cyclocardia occidentalis (Conrad)

Pecten bellus (Conrad)

Gastropoda

Calicantharus humerosus (Gabb)

Crassispira zizyphus Berry

Crepidula princeps Conrad

Echinodermata

Echinoidea

Dendraster venturaensis Kew late
Miocene

early
Pliocene

late
Pliocene

$x$

$X$

$x$

$x$

$x$

$x$

X early

Pleistocene

Pliocene fauna.-As with the middle fauna, the age ranges of some of the taxa presented in Table 4 has changed over recent years as have the ages of the formations which contain them, so the age significance of these taxa is discussed in Appendix 1.

Significant in this fauna is Ocenebra coryphaena Woodring which has not been reported from rocks older than middle Pleistocene. This taxon is rare, so its stratigraphic occurrence is presumably not as well known as the other extinct taxa. It is represented in collections from the Coyote Hills by a single, questionably identified individual, which otherwise suggests a late Pliocene age. If properly identified, the stratigraphic range of $O$. coryphaena Woodring needs to be extended into the late Pliocene.

Another interesting taxon from this collection is Maxwellia eldridgei (Arnold), first described from an oil company well near Newhall, Los Angeles County. Other occurrences, listed by Grant and Gale (1931), are from the same area and were assigned to the early (lower) Pliocene. It is also known from the Niguel Formation in the San Joaquin Hills, southern Orange County (LACMIP collections). Valentine (1961) mentions Maxwellia eldridgei (Arnold) occurring in the Lomita Marl but does not cite reference, locality, or collection. With the exception of its occurrence in San Pedro, which needs to be confirmed, it appears to have a Pliocene age range. 
Table 4.-Stratigraphic ranges of extinct mollusks from the lower (Pliocene) fauna in the East Coyote Hills, Orange County, California

$\begin{array}{lcccc}\text { TAXA/AGE } & \begin{array}{c}\text { late } \\ \text { Miocene }\end{array} & \begin{array}{c}\text { early } \\ \text { Pliocene }\end{array} & \begin{array}{c}\text { late } \\ \text { Pliocene }\end{array} & \begin{array}{c}\text { early } \\ \text { Pleistoce }\end{array} \\ \begin{array}{l}\text { Mollusca } \\ \text { Bivalvia } \\ \text { Dendostrea? vespertina (Conrad) }\end{array} & \mathrm{X} & \mathrm{X} & \mathrm{X} & - \\ \begin{array}{l}\text { Pecten bellus (Conrad) } \\ \text { Gastropoda }\end{array} & - & \mathrm{X} & \mathrm{X} & \mathrm{X} \\ \text { Cancellaria arnoldi (Dall) } & - & - & \mathrm{X} & \mathrm{X} \\ \text { Cancellaria tritonidae (Gabb) } & \mathrm{X} & \mathrm{X} & \mathrm{X} & \mathrm{X} \\ \text { Crassispira zizyphus Berry } & - & - & \mathrm{X} & \mathrm{X} \\ \text { Crepidula princeps Conrad } & \mathrm{X} & \mathrm{X} & \mathrm{X} & \mathrm{X} \\ \text { Maxwellia eldridgei (Arnold) } & - & \mathrm{X} & \mathrm{X} & - \\ \text { Nassarius grammatus (Dall) } & - & \mathrm{X} & \mathrm{X} & - \\ \text { Ocenebra coryphaena Woodring } & - & - & - & - \\ \text { Opalia varicostatum (Stearns) } & - & \mathrm{X} & \mathrm{X} & -\end{array}$

\section{Radiometric dating}

Middle fauna - Maurer and Conkling (written communication, 1998) reported a strontium age determination of $1.4 \pm 0.4 \mathrm{Ma}$ from a Patinopecten caurinus (Gould) collected from the upper part of the "San Pedro" Formation section in the bluffs on the north side of Rosecrans Blvd., Ralph B. Clark Regional Park (LC-60). This determination is in general agreement with the age suggested by the extinct mollusks discussed above (i.e., early Pleistocene).

\section{CONCLUSIONS}

The "San Pedro" Formation in the Coyote Hills contains a fauna of 184 taxa which have been divided into three stratigraphically distinct faunas. The upper fauna represents warm water conditions, probably similar to off the Orange/Los Angeles Counties coast today, or possibly warmer as suggested by several extra-limital southern taxa. It may correlate to warmer part(s) of the Lomita Marl and San Pedro Sands in the San Pedro area, Los Angeles County suggesting a middle Pleistocene age. The middle fauna contains Patinopecten caurinus (Gould) suggests much cooler water conditions than exist locally today; temperatures equivalent to the central California coast today (circa. $36^{\circ} \mathrm{N}$ ) at moderate water depths (circa. 30-60 m). It also contains several extinct taxa which suggest an early Pleistocene, or possibly late Pliocene, age. The biostratigraphic age determination is supported by a Sr-isotope age of 1.4 Ma from Patinopecten caurinus (Gould) from this fauna. The lower, Pliocene fauna, is represented by one collection low in the section in the East Coyote Hills. It is ecologically similar to the middle fauna but lacks the extra-limital northern taxa. It contains several extinct taxa which suggest a Pliocene age and is correlated with the Saugus Formation in the Ventura Basin and the San Diego Formation in San Diego County, California. Above the "San Pedro" Formation in the Coyote Hills Formation is a small fauna suggesting a restricted marine environment.

We conclude that several ecologically distinct faunas exist in the "San Pedro" Formation in the Coyote Hills which represent faunal response to sea-level fluctuations during 
the Quaternary and possibly latest Tertiary. Overlying this is the Coyote Hills Formation, with a few mollusk taxa which possibly represent a restricted marine environment. These fauna suggest at least three sea-level events in the Coyote Hills: from a possibly lowstand for the middle and possibly lower fauna, to a highstand for the upper fauna, and another highstand for the restricted marine fauna in the Coyote Hills Formation. Whether the Pliocene fauna is part of the lower fauna, or represents another lowstand or intermediate conditions, is unclear.

\section{ACKNOWLEDGEMENTS}

We would like to thank Lisa Babalonia (Ralph B. Clark Interpretive Center), Steve Conkling (ISA Associates), Lindsey Groves and LouElla Saul (Invertebrate Paleontology Section, Los Angeles County Museum of Natural History), Patrick Keefe (Eberhart \& Stone, Inc.), and everyone at RMW Paleo Associates, Inc., who made collections and data under their care available for study. We also wish to thank Rich Mooi and Robert Van Syoc (CAS) for help identifying specimens in their specialties. Also Mary McGann and Dan Ponti for their helpful reviews.

\section{REFERENCES}

Addicott, W.O., 1965, Some western American Cenozoic gastropods of the genus Nassarius: U.S. Geological Survey Professional Paper 503B, p. B1-B24. , 1970, Miocene gastropods and biostratigraphy of the Kern River area, California: U.S. Geological Survey Professional Paper 642, $174 \mathrm{p}$.

Addicott, W.O., Poore, R.Z., Barron, J.A., Gower, H.D., and McDougall, K., 1978, Neogene biostratigraphy of the Indian Creek-Shell Creek area, northern La Panza Range, California, in Addicott, W. O., ed., Neogene biostratigraphy of selected areas in the California Coast Ranges: Field conference on marine Neogene of California, International Geological Correlation Programme (IGCP), project 114, 21-24 June 1978. U.S. Geological Survey Open-file Report 78-446, pp. 49-81.

Arnold, D., and Arnold, R. A., 1902, The marine Pliocene and Pleistocene stratigraphy of the coast of southern California: Journal of Geology, v. 10, p. 117-138.

Arnold, R.A., 1903. The paleontology and stratigraphy of the marine Pliocene and Pleistocene of San Pedro, California: California Academy of Sciences, Memoir no. 3, 420 p.

, 1906, The Tertiary and Quaternary pectens of California: U.S. Geological Survey Professional Paper 47, $264 \mathrm{p}$.

, 1907, New and characteristic species of fossil mollusks from the oil-bearing Tertiary formations of southern California: Proceedings of the U.S. National Museum, v. XXXII, p. 525-546.

, 1908a, Descriptions of new Cretaceous and Tertiary fossils from the Santa Cruz Mountains, California: Proceedings of the U.S. Museum of Natural History, v. XXXIV, p. 345-390.

, 1908b, New and characteristic species of fossil mollusks from the oil-bearing Tertiary formations of Santa Barbara Country, California: Smithsonian Miscellaneous Collections, v. IV, no. 4, p. 419-447.

Bernard, F.R., 1983, Catalogue of the living Bivalvia of the eastern Pacific Ocean. Bering Strait to Cape Horn: Canadian Special Publication of Fisheries and Aquatic Sciences, no 61, 102 p. 
Bruff, S.C., 1946, The paleontology of the Pleistocene molluscan fauna of the Newport Bay area, California: University of California Publications, Bulletin of the Department of Geological Sciences, v. 27, no. 6, p. 213-240.

Carson, C.M., 1926, New molluscan species from the California Pliocene. Bulletin of the Southern California Academy of Sciences, v. 25, no. 1, p. 49-62.

Clark, B.L., 1915, Fauna of the San Pablo Group of middle California: University of California Publications, Bulletin of the Department of Geology, v. 8, no. 22, p. 385-572.

Clark, A., 1931, The cool-water Timms Point Pleistocene horizon at San Pedro, California: Transactions of the San Diego Society of Natural History, v. VII, no. 4, p. 25-42.

Coan, E.V., 1983, The eastern Pacific Donacidae: The Veliger, v. 25, no. 4, p. 273-298. 1990, The recent eastern Pacific species of the bivalve family Thraciidae: The Veliger, v. 33, no. 1, p. 20-55.

Coan, E.V., and Scott, P.H., 1997, Checklist of the marine bivalves of the northeastern Pacific Ocean: Santa Barbara Museum of Natural History, Contributions in Science, no. $1,28 \mathrm{p}$.

Dall, W.H, 1898, [a table of the North American Tertiary horizons, correlated with one another and with those of western Europe, with annotations]: U.S. Geological Survey, $18^{\text {th }}$ Annual Report , pt. 2, p. 335.

Durham, D.L., and Addicott, W.O, 1965, Pancho Rico Formation, Salinas Valley, California: U.S. Geological Survey Professional Paper 524A, p. A1-A22.

DuShane, H., 1979, The family Epitoniidae (Mollusca: Gastropoda) in the northeastern Pacific: The Veliger, v. 22, no. 2, p. 91-134.

English, W.A., 1914, The Fernando Group near Newhall, California: University of California Publications, Bulletin of the Department of Geology, v. 8, no. 8, p. 203-218.

Grant, U.S., IV, and Gale, H.R. 1931. Catalogue of the marine Pliocene and Pleistocene Mollusca of California and adjacent regions. Memoirs of the San Diego Society of Natural History, v. 1, 1,036 p.

Grant, U.S., IV, and Hertlein, L.G., 1938, The west American Cenozoic Echinoidea: Publications of the University of California at Los Angeles in Mathematical and Physical Sciences, v. 2, $226 \mathrm{p}$.

Grau, G., 1959, Pectinidae of the eastern Pacific: University of Southern California, Publication of the Allan Hancock Pacific Expeditions, v. 23, 308 p.

Groves, L.T. 1991, Paleontology and biostratigraphy of the Plio-Pleistocene lower Saugus Formation, Santa Susana Mountains, southern California: M.S. thesis, California State University, Northridge, $373 \mathrm{p}$.

Hertlein, L.G., and Grant, U.S., IV, 1972, The geology and paleontology of the marine Pliocene of San Diego, California (Paleontology: Pelecypoda): San Diego Society of Natural History Memoir, v. 2 (part 2B), p. 135-411.

Hetherington, G.E., 1957, Geology of the south Tapo Canyon area, Santa Susana quadrangle, Ventura County, California: M.A. Thesis, University of California, Los Angeles, CA, $93 \mathrm{p}$.

Hoskins, C.W., 1954, Geology and paleontology of the Coyote Hills, Orange County, California: M.A. Thesis, Claremont Graduate School, Claremont, CA, 149 p.

Kanadoff, G.P., and Emerson, W.K., 1959, Late Pleistocene invertebrates of the Newport Bay area, California: Los Angeles County Museum Contributions in Science, no. 31, $47 \mathrm{p}$.

Keen, A.M., 1971, Sea shells of tropical west America. Marine mollusks from Baja Califor- 
nia to Peru: Stanford University Press, Stanford, CA, 1,064 p.

Kew, W.S.W., 1920, Cretaceous and Cenozoic Echinoidea of the Pacific coast of North America: University of California Publications, Bulletin of the Department of Geology, v. 12, no. 2, p. 23-236.

, 1923, Geologic formations of a part of southern California and their correlation: American Association of Petroleum Geologists Bulletin, v. 7, no. 4, p. 411-420.

Lajoie, K.R., Ponti, D.J., Powell, C.L., II, Mathieson, S.A., and Sarna-Wojicicki, A.M., 1991, Emergent marine strandlines and associated sediments, coastal California; a record of Quaternary sea-level fluctuations, vertical tectonic movements, climatic changes, and coastal processes, in Dupré, W. R. and others, eds., Chapter 7, Quaternary geology of the Pacific margin: Vol. K-2 Quaternary Nonglacial geology, conterminous U.S. The geology of North America. p. 190-214.

Langenwalter, P.E., ca. 1978, Paleontologic assessments, in Scientific assessment, Los Coyotes Regional Park, County of Orange: Recreation Systems, Inc., (Fullerton, CA), p. 30-41.

Loel, W., and Corey, W.H., 1932, The Vaqueros Formation, lower Miocene of California. IPaleontology: University of California Publications, Bulletin of the Department of Geological Sciences, v. 22, no. 3, p. 31-410.

Martin, B., 1916, The Pliocene of middle and northern California. University of California Publications, Bulletin of the Department of Geology, v. 9, no. 15, p. 215-259.

McLean, J.H. 1978. Marine shells of southern California: Natural History Museum of Los Angeles County, Science Series, no. 24 (revised edition), 104 p.

McLean, J.H., and Grosliner, T. M. 1996. The Mollusca Part 2, The Gastropoda, in Scott, P. H., Blake, J. A., and Lissner, A.L., eds., Taxonomic atlas of the benthic fauna of the Santa Maria Basin and western Santa Barbara Channel: v. 9, p. 1-228.

Moody, C.L., 1916, Fauna of the Fernando of Los Angeles: University of California Publications, Bulletin of the Department of Geology, v. 10, no. 4, p. 39-62.

Moore, E.J. 1983. Tertiary marine pelecypods of California and Baja California. Nuculidae through Malleidae: U.S. Geological Survey Professional Paper 1228A, p. A1-A108. , 1984. Tertiary marine pelecypods of California and Baja California. Propeamussiidae and Pectinidae: U.S. Geological Survey Professional Paper 1228B, p. B1-B112.

, 1999, Tertiary marine pelecypods of California and Baja California, Chapter F: http:// www.cmug.com/ chintimp/Tertiary.pelecypods.htm, 107 p.

Morris, R.H., Abbott, D.P., and Haderlie, E.C., 1980, Intertidal invertebrates of California: Stanford University Press, Stanford, CA, $690 \mathrm{p}$.

Nelson, C.M., 1974, Evolution of the late Cenozoic gastropod Neptunea (Gastropoda: Buccinacea): Ph.D. Dissertation, University of California at Berkeley, Berkeley, CA., $803 \mathrm{p}$.

Poland, J.F., Piper, A.M., and others, 1956, Groundwater geology of the coastal zone, Long Beach-Santa Ana area, California: U.S. Geological Survey Water Supply Paper 1109: $162 \mathrm{p}$.

Ponti, D.J., 1989, Aminostratigraphy and chronostratigraphy of Pleistocene marine sediments, southwestern Los Angeles Basin, California: Golden, CO. Ph.D. dissertation, University of Colorado, Golden, $409 \mathrm{p}$.

Powell, C.L., II. 1998. The Purisima Formation and related rocks (upper MiocenePliocene), greater San Francisco Bay area, central California. Review of literature 
and USGS collections (now housed at the Museum of Paleontology, University of California, Berkeley): U.S. Geological Survey Open-file Report 98-594, 102 p.

Powell, C.L., II, Lajoie, K., Ponti, D.J., in press, A preliminary chronostratigraphy based on molluscan biogeography for the late Quaternary of southern California: Submitted to the Annual Report, Western Society of Malacologists 1999, $22 \mathrm{~ms} \mathrm{p.}$

Powell, C.L., II, and Stevens, D., 1999, Age and paleoenvironmental significance of mollusks from the "San Pedro" Formation, Coyote Hills, Orange County, southern California: Western Society of Malacologists, Program and abstracts (32 ${ }^{\text {nd }}$ Annual Meeting), p. 30 (unnumbered).

, in press, Significance of macrofossils from the "San Pedro" Formation, Coyote Hills, Orange County, southern California: Submitted to the Annual Report, Western Society of Malacologists 1999, $9 \mathrm{~ms}$ p.

Pressler, E.D., 1929, The Fernando Group in the Las Posas-South Mountain District, Ventura County, California: University of California Publications, Bulletin of the Department of Geological Sciences, v. 18, no. 13, p. 325-345.

Reish, D.J., 1952, Discussion of the colonial tube-building polychaetous annelid Dodecaceria fistulicola Ehlers: Bulletin of the Southern California Academy of Sciences, v. 51, pt. 3, p. 103-107.

RMW Paleo Associates, 1996, Paleontological monitoring and salvage report - East Coyote Hills Project, Fullerton, Orange County, California: RMW Paleo Associates Report 93-1091, prepared for Unocal Land \& Development Co., 16 + additional unnumbered pages.

Rathbun, M.J., 1926, The fossil stalk-eyed Crustacea of the Pacific slope of North America: U.S. National Museum Bulletin, v. 138, 155 p.

Richey, K.A., 1943, A marine invertebrate fauna from the Orinda, California, Formation. University of California Publications, Bulletin of the Department of Geological Sciences, v. 27, no. 2, p. 25-36.

Shinn, J.R., 1999, Paleontological monitoring and salvage report PLC-La Habra Hills, La Habra, Orange County, California: Report 96-1074, prepared for PLC, 15 + additional unnumbered pages.

Stanton, R.J., Jr., 1966, Megafauna of the upper Miocene Castaic Formation, Los Angeles County, California: Journal of Paleontology, v. 40, no. 1, p. 21-40.

Valentine, J.W., 1961, Paleoecologic molluscan geography of the Californian Pleistocene: University of California Publications in Geological Sciences v. 34, no. 7, p. 309-442.

Vedder, J.G. and Norris, R.M., 1963, Geology of San Nicolas Island, California: U.S. Geological Survey Professional Paper 369, $65 \mathrm{p}$.

Webb, R.W., 1937, Paleontology of the Pleistocene of Point Loma, San Diego County, California: Transactions of the San Diego Society of Natural History, v. VIII, no. 24, p. 337-348.

Weir, D. and Morgan, M., 1982, Paleontological report: fossil vertebrate and invertebrate localities in the San Pedro Formation, Emery Property, Fullerton, California: RMW Paleo Associates Report, prepared for The William Lyon Co., $16 \mathrm{p}$.

Willett, G., 1937, An upper Pleistocene fauna from the Baldwin Hills, Los Angeles County, California: Transactions of the San Diego Society of Natural History v. VIII, no. 30, p. 379-406.

Woodring, W.P., and Bramlette, M.N., 1950, Geology and paleontology of the Santa Maria District, California: U.S. Geological Survey Professional Paper 222, p. 185 p. 
Woodring, W.P., Bramlette, M.N., and Kew, W.S.W., 1946, Geology and paleontology of Palos Verdes Hills, California: U.S. Geological Survey Professional Paper 207, 145 p.

Yancey, T.E., 1978, Stratigraphy of the Plio-Pleistocene strata in the Twelvemile Creek area, San Francisco Peninsula, California: Proceedings of the California Academy of Sciences, Fourth Series v. 41, no. 5, p. 357-370.

Yerkes, R.F., 1972, Geology and oil resources of the western Puente Hills area, southern California: U.S. Geological Survey Professional Paper 420C, 63 p.

Yerkes, R.F., McCulloh, T.H., Schoellhamer, J.E., and Vedder, J.G., 1965, Geology of the Los Angeles basin - an introduction: U.S. Geological Survey Professional Paper 420A, p. A1-A57.

Zinsmeister, W.J., 1970, A late Pliocene macrofossil fauna Newport Beach, Orange County, California. Bulletin of the Southern California Academy of Sciences, v. 69, no. 3/4, p. 121-125. 


\title{
Appendix 1: Selected faunal notes
}

Discussed here are taxonomic, stratigraphic, and/or environmentally significant taxa either reported or recovered from the "San Pedro" Formation in the Coyote Hills, Orange County, California.

\author{
Phylum ANNELIDA \\ Class POLYCHAETA
}

\section{Family CIRRATULIDAE}

Two distinct worms are recognized from the "San Pedro" Formation in the Coyote Hills. The first is composed of small, closed spaced calcareous tubes, which were identified by Reish (1952) as Dodecaceria fistulicola Ehlers. In California, this species has a fossil record from the late Miocene (Santa Margarita Formation) to middle Pleistocene (unspecified formation on Deadman Island in San Pedro; this restricts it to the Lomita Marl, Timms Point Silt, or San Pedro Formation, all of middle Pleistocene age). The later taxon is discussed under the family Serpulidae(?).

\section{Family SERPULIDAE(?)}

Large calcareous tubes up to $1+\mathrm{cm}$ diameter and $10 \mathrm{~cm}$ long have been collected from the "San Pedro" Formation in the Coyote Hills and are questionably placed in the worm family Serpulidae. There are no diagnostic features for a specific determination. It is not even clear if these specimens belong in the Phylum Annelida or Mollusca. Specimens similar to these have also been found in the Pliocene Niguel and Santa Barbara formations, questionably from the Sisquoc Formation (as an indeterminate Vermetid mollusk; Woodring and Bramblett, 1950), and from the Pleistocene Lomita Marl (Woodring and others, 1946; as indeterminate Vermetid mollusks).

\section{Phylum MOLLUSCA Class BIVALVIA}

\section{Family NUCULIDAE}

Yerkes (1972) reported Acila castrensis (Hinds) from his locality F12 in the West Coyote Hills. This locality appears to correlate with Hoskins (1954) locality F6 which was not given a Pomona College number. Examination of specimens at Pomona College with Hoskins (1954) F6 field number did not include Acila castrensis (Hinds) so its occurrence in the "San Pedro" Formation in the Coyote Hills, although likely, needs confirmation. For this reason, it is not used for age and/or environmental interpretations.

\section{Family ARCIDAE}

Larkinia camuloensis (Osmont) [as Anadara camuloensis (Osmont)] has been reported from the "San Pedro" Formation in the West Coyote Hills by Yerkes (1972) from his locality F5. Yerkes' (1972) specimens could not be located and no other specimens of this taxon are in collections from the Coyote Hills, so its occurrence there, although possible, needs confirmation. For this reason it is not used for age and/or environmental interpretations.

\section{Family MYTILIDAE}

Five Mytilids are reported from the "San Pedro" Formation in the Coyote Hills: Solamen columbianum (Dall), Mytilus californicus Conrad, M. coalingensis Arnold, M. trossulus Gould [as $M$. edulis Linnaeus], and Modiolus rectus (Conrad). Three of these taxa are significant and are discussed below.

The report of Solamen columbianum (Dall) from the "San Pedro" Formation in the Coyote Hills (Hoskins, 1954) is the first reported fossil occurrence of this taxa and the specimen was verified during this study. Mytilus coalingensis Arnold has a restricted stratigraphic range in rocks from 
southern and central California from the late Miocene to late Pliocene, possibly early Pleistocene age (Moore, 1983). Lastly, Modiolus rectus (Conrad) as recognized by Bernard (1983) occurs mostly south of the fossil locality today $\left(5^{\circ} \mathrm{S}\right.$ to $\left.35^{\circ} \mathrm{N}\right)$, but recently Coan and Scott (1997) synonymized it with $M$. flabellatus (Gould) under the former name. If this synonymy is accepted the range of this taxon would be extended, from $35^{\circ} \mathrm{N}$ to $54^{\circ} \mathrm{N}$, eliminating it as an ecologically significant taxon.

\section{Family OSTREIDAE}

Dendostrea? vespertina (Conrad) s.l. occurs in Miocene to Pliocene rocks in Baja California, as well as southern and central California. It was described from the Imperial Formation in eastern San Diego County and western Imperial County from deposits associated with the ancestral Gulf of California. Specimens referred to this species from coastal California are generally larger and rounder in outline than the typical form but in all other features are very similar to Imperial Formation specimens. In my opinion these specimens are referable to a different taxon, but separating the two species is beyond the scope of this paper.

\section{Family PECTINIDAE}

Argopecten ventricosus (Sowerby) [syn. A. circularis (Sowerby); syn. A. aequisulcatus (Carpenter, 1864)] has been reported from Elkhorn Slough, Monterey Bay, California, south to Paita, Peru, including the Galapagos Islands (Grau, 1959). McLean (1978) reported its [as $A$. aequisulcatus (Carpenter)] northern end point as the Santa Barbara Islands. Bernard (1983), studying only live collected specimens in various West Coast museum reports its northernmost occurrence at $30^{\circ} \mathrm{N}$ [as $A$. circularis (Sowerby)]. I (Powell) have occasionally seen specimens living in bay and lagoons in Orange and San Diego Counties, but reproducing populations of this taxon probably do not occur north of Baja California, Mexico. Therefore, we follow Bernard (1983) and designate $A$. ventricosus (Sowerby) as an extra-limital southern taxon.

Chlamys anapleus Woodring has previously been reported only from the Lomita Marl and San Pedro Sands in the San Pedro area, Los Angeles County (Woodring and others, 1946). It is questionable reported from the Coyote Hills from Hoskins locality PC264 examined during this study but was not reported by Hoskins (1954). This collection contains warm water taxa and is referred to the upper, warm water, fauna herein. If this identification proves correct, then it suggests either 1) an age range extension to the early Pleistocene for this taxon, or 2) the warm water fauna in the Coyote Hills is probably middle Pleistocene.

Coan and Scott (1997) suggested that Chlamys islandica (Gmelin) does not occur in the eastern Pacific or Alaskan waters and that all specimens previously attributed to this species in the eastern Pacific should be referred to $C$. beringiana (Middendorff). This suggestion is followed here. They also suggest that Chlamys rubida (Hinds) and $C$. jordani (Arnold) are synonymous under the former name and that suggestion is also followed.

The Miocene age reported for Chlamys opuntia (Dall), Flabellipecten stearnsii (Dall) and Pecten bellus (Conrad) by Moore (1984) is based on these taxa occurring in the Purisima Formation (Arnold, 1906). But Arnold was referring to Purisima-age faunas, not to the Purisima Formation s.s. These taxa do not exist in collections from the Purisima Formation (collections examined include: California Academy of Sciences; Los Angeles County Museum of Natural History, University of California, Berkeley, Museum of Paleontology; and U.S. Geological Survey; see also Powell, 1998). Otherwise Chlamys opuntia (Dall) occurs in probably Pliocene to early Pleistocene rocks in central and southern California, Flabellipecten stearnsii (Dall) occurs in late(?) Pliocene to middle Pleistocene sediments in southern California and Baja California, Mexico, and Pecten bellus (Conrad) occurs in late Pliocene to early Pleistocene sediments in southern California and Baja California, Mexico (Moore, 1984). It is generally thought that Pecten bellus (Conrad) has a first occurrence at about the Pliocene - Pleistocene boundary and its last occurrence in the middle Pleistocene (see occurrences in Moore, 1984). In most collections in the Coyote Hills it is associ- 
ated with the cool water fauna, but Welton and others (MS) report it occurring with a neutral to possibly warm water fauna near the top of the San Pedro Formation at Ralph Clark Regional Park.

Other significant Pectinids include Lyropecten cerrosensis (Gabb) and Patinopecten caurinus (Gould). Lyropecten cerrosensis (Gabb) is reported from a single collection by Hoskins (1954) in the West Coyote Hills. Its occurrence has not been verified so it is not included in age interpretations. Patinopecten caurinus (Gould) is extant and has a modern occurrence from central California $\left(36^{\circ} \mathrm{N}\right)$ to the Gulf of Alaska $\left(59^{\circ} \mathrm{N}\right)$ in water from 10 to $200 \mathrm{~m}$ deep (Bernard, 1983). It suggests cooler water conditions than exists along the Orange County coast today.

\section{Family CARDITIDAE}

Cyclocardia from the "San Pedro" Formation in the Coyote Hills are all attributed to Cyclocardia sp., aff. C. occidentalis (Conrad) of Woodring and others (1946). Woodring and others (1946) report this taxon as common in the Lomita Marl and Timms Point Silt, uncommon in the San Pedro Sand, and rare in the Palos Verdes Sand. They do not state how it differs from specimens of C. occidentalis (Conrad) from the type locality in the Santa Barbara Formation (late Pliocene to early Pleistocene). Based on its occurrence in the San Pedro area (Woodring and others, 1946) and in the Coyote Hills, it probably ranges in age from near the Pliocene/Pleistocene boundary to middle Pleistocene (Powell and others, MS). It is common in some collections in the San Pedro area where it is associated with taxa representing offshore conditions equivalent to the Lucinoma annulata - Turcica caffea and Thyasira gouldi - Neptunea tabulata communities of Valentine (1961). Valentine reports the Lucinoma annulata - Turcica caffea community as representing deep inner sublittoral water depths (18-23 to $46 \mathrm{~m}$ ) and the Thyasira gouldi - Neptunea taubulata community representing shallow outer sublittoral water depths $(46-90 \mathrm{~m})$. This is in accordance with the depth range suggested by other taxa associated with Cyclocardia sp., aff. C. occidentalis (Conrad) of Woodring and others (1946) in the Coyote Hills.

\section{Family TELLINIDAE}

Leporimetis obesa (Deshayes) is extant and has a modern occurrence from Point Conception, California $\left(35^{\circ} \mathrm{N}\right)$ to Magdalena Bay, Baja California Sur, Mexico $\left(25^{\circ} \mathrm{N}\right)$ (McLean, 1978) in water depths from the intertidal zone to $50 \mathrm{~m}$ (Bernard, 1983). It is reported from the upper fauna here and suggests water temperatures equal to, or perhaps slightly warmer, than exists along the Orange County coast today.

\section{Family DONACIDAE}

Both the Donax species reported here occur only in the upper fauna. Donax californicus Conrad is extant and ranges from Santa Barbara, through the Gulf of California, and south to Puerto Pizarro, Tumbez Province, Peru (Coan, 1983). This geographic range suggests water temperatures equal to, or possibly higher than exists along the Orange County coast today. Donax gouldii Dall has a modern occurrence from Santa Cruz County, central California south to southern Baja California, but is sporadic north of Point Conception (McLean, 1978). In the southern California Pleistocene it is found associated with taxa suggesting water temperatures the same or warmer than those occurring off the adjacent coast today, and is part of the upper fauna in the Coyote Hills.

\section{Family CARDIIDAE}

Despite its name Trachycardium panamense (Sowerby) is an extra-limital southern taxon with a modern range from Baja California south to only Costa Rica (Keen, 1971). It is common in warmer water faunas in southern California and is herein included in the upper, warm water, fauna of the Coyote Hills. The species was collected at only one locality (LACM 477).

\section{Family VENERIDAE}

The genus Chione, although not extra-limital, has a geographic range mainly south of the 
fossil locality, suggesting water temperatures as warm or possibly warmer than those existing along the Orange County/Los Angeles County coast today. McLean (1978) reported Chione californiensis (Broderip in Broderip \& Sowerby) from Carpenteria, California, to Panama, and Chione undatella (Sowerby) from Goleta, California to Peru. Both of these taxa are reported from the upper fauna.

Both Hoskins (1954) and Yerkes (1972) report Nutricola lordi (Baird) from the West Coyote Hills. Specimens available for study at Pomona College and LACMIP appear to be referable to $N$. tantilla (Gould). Until specimens referable to N. lordi (Baird) are located, it's occurrence in the "San Pedro" Formation in the Coyote Hills is questioned. Therefore it is not used for environmental interpretations here.

\section{Family MACTRIDAE}

The family Mactridae has recently been reviewed by Moore (1999) and her recommendations for generic assignment are applied in this study. Three Mactrids have been reported from the "San Pedro" Formation in the Coyote Hills, but only one is possibly ecologically significant.

Mactromeris hemphilli (Dall) has a modern range from Santa Barbara south to Ensenada, Baja California Norte, Mexico (McLean, 1978). This taxon occurs only in the upper fauna of the Coyote Hills and suggests water temperatures similar to today or possibly slightly warmer. The specimen illustrated by Hoskins (1954) does not show the posterior ridge characteristic of this species and may be referable to some other taxon, but this species was observed in collections at Pomona College.

\section{Family THRACIIDAE}

Work by Coan (1990) suggests that Cyathodonta species recorded from the California Pleistocene are probably referable to Cyathodonta pedroana Dall. Cyathodonta pedroana Dall is the only eastern Pacific taxon in this genus, which has a modern range extending into California. It is possible that $C$. undulata Conrad and/or $C$. dubiosa Dall are present in the California Pleistocene as some outcrops represent significantly warmer water temperatures than occur along with adjacent coast today, but this must await confirmation. All specimens identifiable to species during the current study are referred to C. pedroana Dall.

\section{Family PANDORIDAE}

Bernard (1983) cites the range of Pandora wardiana Adams as $47^{\circ} \mathrm{N}$ (Washington) to $57^{\circ} \mathrm{N}$ (Gulf of Alaska) in water depths from $40 \mathrm{~m}$ to $200 \mathrm{~m}$, making this another cool water, northern extralimital taxon.

\section{Class GASTROPODA}

\section{Family HALIOTIDAE}

A small fragment attributed with some confidence to Haliotis cracherodii Leach is present in collections at Ralph B. Clark Regional Park. If this specimen is referable to $H$. cracherodii Leach, then the "San Pedro" Formation in the Coyote Hills may represent the oldest fossil occurrence of this taxon. Unfortunately, the field number from which the specimen was collected lacks locality data and therefore it cannot be placed with confidence into the stratigraphic succession at Ralph B. Clark Regional Park. Previously, the oldest occurrences of $H$. cracherodii Leach are from the 735' terrace on San Nicolas Island (Vedder and Norris, 1963), which is probably less than 1 million years old (D. Muhs, written commun., 1998), and from the $13^{\text {th }}$ terrace on the Palos Verdes Peninsula (Woodring and others, 1946) which Ponti (1989) suggests is middle Pleistocene (<720 ka) in age.

\section{Family TROCHIDAE}

Tegula pulligo (Gmelin) has a modern range from Sitka, Alaska, to Baja California. It is uncommon on low intertidal rocks inshore of kelp beds but more common subtidally on large algae 
in kelp forests (Morris and others, 1980). It has rarely been reported as a fossil and apparently only in late Pleistocene deposits in southern California: Orange County (Bruff, 1946), San Diego County (Webb, 1937), and Los Angeles County (Arnold, 1903; Willett, 1937). This makes its occurrence here the oldest record of this taxon.

\section{Family EPITONIIDAE}

Five Epitonids have been reported from the "San Pedro" Formation in the Coyote Hills: $E$. bellastriata (Carpenter), E. indianorum (Carpenter), E. sawinae (Dall), Opalia borealis Keep, and $O$. varicostatum (Stearns) (questionably identified here). Only E. indianorum (Carpenter) and $O$. varicostatum (Stearns) are discussed below.

Epitonium indianorum (Carpenter) has been reported from Forrester Island, Alaska south to Bahia Todos Santos, Baja California Sur, Mexico (DuShane, 1979) in water depths from the intertidal zone to $120 \mathrm{~m}$ (McLean and Grosliner, 1996). It is reported from the "San Pedro" Formation in the Coyote Hills by Hoskins (1954) and Yerkes (1972) but the specimens on which these occurrences are based were only identified as indeterminate species during the present study. Therefore, the occurrence of E. indianorum (Carpenter) in the "San Pedro" Formation of the Coyote Hills, Orange County must await confirmation. Previous records of $O$. varicostatum (Stearns) are from the Pliocene of southern California; thus its occurrence in the "San Pedro" Formation of the Coyote Hills suggests a Pliocene age for the part of the Formation in which it was collected.

\section{Family CREPIDULIDAE}

Crepidula princeps (Conrad) ranges in age from late Miocene to middle Pleistocene. The middle Pleistocene age is based on its occurrence in the Timms Point Silt (Clark, 1931), which according to Lajoie and others (1991), is middle Pleistocene in age. Late Pleistocene occurrences, such as at Newport Bay (Kanakoff and Emerson, 1959), represent reworked specimens judging by their preservation and color.

\section{Family CALYPTRAEIDAE}

Much confusion exists, especially in the fossil record, between Calyptraea spirata (Forbes)

and $C$. trochiformis (Born). According to Keen (1971) these two taxa are separable on several counts including size, color, sculpture, and distribution. Calyptraea spirata (Forbes) has a modern occurrence from Mazatlán, Mexico south to the Gulf of Tehuantepec, Mexico, while C. trochiformis (Born) occurs from Manta, Ecuador south to Valparaiso, Chile. The name C. trochiformis (Born) has been used for Neogene fossils in southern and central California by Grant and Gale (1931) and followed by later authors. Based on modern occurrence alone, fossil specimens from southern California are probably better referred to $C$. spirata (Forbes) s.I. It is likely, however, that $C$. spirata (Forbes) in the Tertiary of southern California represents a species complex of several taxa because of the wide stratigraphic range and variability exhibited by individuals specimens associated with this species name. Fossil occurrence of taxa assigned to, and similar to, $C$. spirata (Forbes) in California include: C. costellata (Conrad) and C. costellata panzana Loel and Corey from the Ladera Sandstone (Arnold, 1908a fide Powell, 1998), the Vaqueros and Temblor formations (Loel and Corey, 1932), the Topanga Formation (Arnold, 1907), and questionably from the Jewett Sand in Kern County [Loel and Corey, 1932; Addicott, 1970 as C. sp., cf. C. spirata (Forbes)]; C. diabloensis Clark from the lower San Pablo Group (Clark, 1915); C. martini Clark the upper San Pablo Group in Contra Costa County and the Santa Margarita Formation north of Coalinga, Kings County (Clark, 1915; Grant and Gale, 1931), and the Orinda Formation of Contra Costa County (Richey, 1943 as "cf."); C. radians (Lamarck) from the Purisima Formation (Martin, 1916), Foxen Mudstone [Fugler Point (=Waldrof) asphalt mine (Arnold, 1908b; Grant and Gale, 1931), the Cebada Member of the Carega Sandstone (Woodring and Bramblette, 1950) both in Santa Barbara County, the "Fernando" Formation near Newhall (English, 1914), the Fernando Formation in downtown Los Angeles (Moody, 1916), and the Pico Formation in the Puente Hills (Carson, 1926), all in Los Angeles 
County; C. spirata (Forbes) from the Santa Margarita Formation (Addicott and others, 1978); C. trochiformis (Born) from the Topanga Formation (Arnold, 1907; Grant and Gale, 1931), and the Fernando Formation of Newport Bay (Zinsmeister, 1970). These taxa show overlapping stratigraphic and geographic ranges which can only be resolved with further study.

The only other Calyptraeid from the "San Pedro" Formation in the Coyote Hills is Crucibulum spinosum (Sowerby). McLean (1978) reports its modern occurrence as San Pedro, Los Angeles County, California south to Chile. It occurrence here is from the upper "warm water" fauna and supports the warm water temperature interpretation of this fauna.

\section{Family MURICIDAE}

Four muricids of note are present in collections from the "San Pedro" Formation in the Coyote Hills. Boreotrophon multicostatus (Eschscholtz) is here considered a cold-water faunal element in that its range is mostly north of the fossil locality. McLean and Gosliner (1996) report it from Laguna Beach, Orange County, California $\left(33.5^{\circ} \mathrm{N}\right)$ north to Kenai Peninsula, Alaska $\left(59^{\circ} \mathrm{N}\right)$. They also reported the depth range of this taxon as intertidal to $100 \mathrm{~m}$, with specimens from southern California as being submerged below $40 \mathrm{~m}$. Boreotrophon pedroana (Arnold) described from the Pleistocene of the San Pedro area was recently shown to be extant from Santa Rosa Island $\left(34^{\circ} \mathrm{N}\right)$ to Isla Todos Santos, Baja California Norte, Mexico $\left(32^{\circ} \mathrm{N}\right)$ in water depths from 40 to $270 \mathrm{~m}$ (McLean and Grosliner, 1996). Ocenebra coryphaena Woodring is present in one collection from the east Coyote Hills (RMW/JRS 855). Previously this taxon was only reported from the Lomita Marl in San Pedro (Woodring and others, 1946) suggesting a middle Pleistocene age for its occurrence. But other taxa associated with it in the Coyote Hills, including the next taxon, suggest a Pliocene age. This suggests a chronologic range extension for this taxon. The last is Maxwellia eldridgei (Arnold) which was described from an oil company well near Newhall, Los Angeles County. Other occurrences listed by Grant and Gale (1931) are from the same area, and all occurrences were assigned to the early (lower) Pliocene (Grant and Gale, 1931). Maxwellia eldridgei (Arnold) is also known from the Niguel Formation in the San Joaquin Hills, southern Orange County (LACMIP collections). Valentine (1961) mentions Maxwellia eldridgei (Arnold) occurring in the Lomita Marl but does not cite reference, locality, or collection. Since I can find no other record of this taxon from the Lomita Marl and have not observed it there myself, its occurrence in the Lomita Marl is questioned. Discounting Valentine's reference, the species' occurrence in the "San Pedro" Formation of the Coyote Hills (as does its occurrence in the Niguel Formation) extends its stratigraphic range from possibly late Pliocene to early Pleistocene.

Here I follow McLean (1978) in considering Ocenebra squamulifera Carpenter and $O$. fusconotata Dall synonymous with $O$. foveolata (Hinds).

\section{Family BUCCININAE}

Neptunea tabulata (Baird) has a modern occurrence from Dixon Entrance, north of Queen Charlotte Island, British Columbia, southward to the Gulf of Santa Catalina, and off San Diego, California, in water depths between $90 \mathrm{~m}$ and $250 \mathrm{~m}$ (Nelson, 1978). This taxon suggests cooler water conditions than present in shallow water along the adjacent coast today.

\section{Family PISANIINAE}

Two extinct Calicantharus are found in the "San Pedro" Formation in the Coyote Hills. Calicantharus fortis (Carpenter) is found questionably in the upper, warm water, fauna and has been reported in rocks of late Miocene [Castaic Formation (Stanton, 1966)] to late Pleistocene [Palos Verdes Sands and San Pedro Formation (Woodring and others, 1946)] from southern and central California. Calicantharus humerosus (Gabb) (questionably identified here) is found presumably in the middle, cool water, fauna (based on stratigraphic position) and has been previously reported from early Pliocene Pancho Rico Formation (Durham and Addicott, 1965) to the late 
Pliocene to Pleistocene Saugus Formation (Hetherington, 1957).

Family NASSARIIDAE

Keen (1971) reports Nassarius cerritensis (Arnold) as living along the "Outer coast of Baja California through the Gulf of California to Bahia San Luis Gonzaga and Guaymas, in depths of 35 to $55 \mathrm{~m}$," and is here considered an extra-limital southern taxon. It is a common warm water indicator taxon in the Pleistocene of southern California and here occurs in the upper fauna.

Nassarius grammatus (Dall) has been recognized from the "San Pedro" Formation in the Coyote Hills in collections at Pomona College. According to Addicott (1965) this species is "one of the more widespread and characteristic mollusks which occur in formations generally considered to be Pliocene in the standard Pacific coast provincial classification...."

\section{Family OLIVIDAE}

Olivella pedroana (Arnold) has been reported from the "San Pedro" Formation in the Coyote Hills by Hoskins (1954) and Yerkes (1972). Specimens in the collections at Pomona College are here identified as $O$. baetica Carpenter and $O$. biplicata (Sowerby) so the occurrence of $O$. pedroana (Arnold) is in doubt and must await confirmation.

\section{Family CANCELLARIIDAE}

Three extinct Cancellarids occurs in the "San Pedro" Formation of the Coyote Hills: Cancellaria arnoldi (Dall), C. fergusoni Carson, and C. tritonidae (Gabb). According to Powell (1998) C. arnoldi (Dall) is found in late Pliocene to possibly early Pleistocene formations from central California to southern California. Cancellaria fergusoni Carson (syn. C. sanctae-mariae Carson) also has a restricted stratigraphic range from late Pliocene to early Pleistocene from the Careaga Sandstone of Santa Barbara County, and the Saugus Formation at Barlow's Ranch, Ventura County (Carson, 1926). It is also found in the Niguel Formation in Orange County (LACMIP and UCR collections) and San Diego Formation in San Diego County (LACMIP collections). Cancellaria tritonidae (Gabb) s.l. occurs in rocks from early (?) Pliocene to late Pleistocene (Grant and Gale, 1931; Powell, unpublished data) in southern California and Baja California Norte.

\section{Family TURRIDAE}

Twelve turrids have been reported from the "San Pedro" Formation in the Coyote Hills: Clathromangelia variegata (Carpenter), Clathurella sp., "Crassispira montereyensis" (Stearns), $C$. semiinflata (Grant and Gale), C. zizyphus Berry, Crockerella conradiana (Gabb), Cymatosyrinx hemphilli (Stearns), Megasurcula carpenteriana (Gabb), Ophiodermella mercedensis (Martin), 0. inermis (Reeve), Pseudomelatoma sp. cf. P. pencillata (Carpenter) and indeterminate specimens referable to the family Turridae. Judging from a photograph in Hoskins (1954) [and followed by Yerkes (1972)] Crassispira montereyensis (Stearns) is actually C. zizyphus Berry. Crassispira zizyphus Berry is an extinct taxon described from the Lomita Marl in the San Pedro area, and also known from the Pico Formation in the Whittier Hills, Los Angeles County (Pomona College loc. 136, fide USGS report on referred fossils by W. Addicott, O-68-9M; 3/1968), the Fernando Formation at Newport Bay, Orange County (LACMIP and UCR collections), and the Niguel Formation in the San Joaquin Hills, Orange County (LACMIP collections). These occurrences suggest a late Pliocene to middle Pleistocene age range for this taxon. Crassispira semiinflata (Grant and Gale) was reported and illustrated from the "San Pedro" Formation in the Coyote Hills by RMW Paleo Associates (1996) but was not found in any collections examined. Based on the illustration this species is expected in the "San Pedro" Formation in this area, but its occurrence needs to be verified. Ophiodermella mercedensis (Martin) was reported from the "San Pedro" Formation in the Coyote Hills by Hoskins (1954) and Yerkes (1972). Woodring and Bramblett (1950) considered Ophiodermella mercedensis (Martin) to be a replacement name for O. graciosana (Arnold, 1907), but both are distinct taxa and forms a stratigraphic succession (Yancey, 1978) in central California. The occurrence of $O$. 
mercedensis (Martin) in the "San Pedro" Formation in the Coyote Hills is south of its known geographic range and specimen(s) could not be located in collections. One specimen attributed to this species in the collections at Pomona College was identifiable only to genus. Therefore, its occurrence in the "San Pedro" Formation is questioned until better specimens can be examined, and it is not used for age or environmental interpretations.

Family TEREBRIDAE

Examination of collections at Pomona College indicated that Hoskins' (1954) specimens of Terebra pedroana Dall are referable to $T$. danai Berry which was described a few years after Hoskins' (1954) thesis.

Family ACTEONIDAE

A single internal mold identified by Hoskins (1954) as Acteon traski Stearns is herein referred to Acteon? sp. indeterminate.

\section{Phylum ARTHROPODA Class CRUSTACEA}

\section{Family LEUCOSIIDAE}

Randallia ornata (Randall, 1839) has been reported from late Pleistocene deposits in southern California (Rathbun, 1926) at Potrero Canyon and Long Wharf in Santa Monica, Nob Hill (lumber yard) and Deadman Island in San Pedro, Signal Hill in Long Beach, and Spanish Bight in San Diego Bay. The specimen reported here records the oldest occurrence of this taxon. Also of interest is that of the two specimens collected as float from the western Coyote Hills one represents a male the other has yet to be determined.

\section{Phylum ECHINODERMATA Class ECHINOIDEA}

\section{Family DENDRASTERIDAE}

According to Grant and Hertlein (1938) Dendraster venturaensis Kew has been reported from the Pliocene of northern Los Angeles County and Ventura County [Santa Clara Valley, north of San Fernando Valley, Las Posas Hills (Kew, 1920), and "Ventura 'Saugus"' and "Kalorama horizon" (Pressler, 1929)]. It is interesting that Grant and Hertlein (1938) cite this species as co-occurring with Patinopecten caurinus Gould and stratigraphically above outcrops containing Pecten bellus (Conrad), as it occurs with both taxa in the Coyote Hills. Although this taxon appears to have a restricted stratigraphic range, some modern specimens of $D$. excentricus Eschscholtz are indistinguishable from this taxon and it is likely to be placed in synonymy at a later date (R. Mooi, personal communication, 1998).

As discussed above, specimens herein referred to Dendraster venturaensis Kew fall within the range of variability of modern Dendraster excentricus Eschscholtz, so the occurrence of specimens questionably referred to the latter are expected. The specimen illustrated by Hoskins (1954) as $D$. cf. $D$. excentricus Eschscholtz is here referred to $D$. venturaensis Kew. 


\section{Appendix 2: Fossil localities and faunal list}

Because of the large number of fossil localities and taxa present in the "San Pedro" Formation of the Coyote Hills the occurrence data is present here as a list. An oversize table, nearly $2 \mathrm{~m}$ long and 1 wide, of the occurrence data can be obtained by contacting the lead author.

Unfortunately nearly all fossil sites with the exception of those in the Ralph C. Clark Regional Park have been lost to development. Fossil localities are illustrated for the north West Coyote Hills in Figure 6, the southern West Coyote Hills, including Ralph C. Clark Regional Park in Figure 7, the eastern West Coyote Hills in Figure 8, and for the East Coyote Hills in Figure 9. The stratigraphic occurrence of fossil localities is presented for the northern West Coyote Hills in Figure 2, for the southern West Coyote Hills, including Ralph C. Clark Regional Park in Figure 3, and the East Coyote Hills in Figure 4.

All specimens were identified by C. Powell, II unless otherwise noted.

\section{Los Angeles County Museum of Natural History}

LACMIP 477. Pleistocene invertebrate fossils collected by Mr. Ojeda from a locality described on the accession data sheet as "Excavations on top of hill at the extension of Rosecrans Ave. after it crossing the Beach Blvd., at the LA-Orange County borderline." Locality further detailed by Paul Langenwalter as "... N side of Rosecrans, 500-600' E of Buena Park underground reservoir and 500-600' N of Rosecrans. Barrow pit used by California Division of Highways; now Los Coyotes Regional Park..." Collected by Mr. Ojeda. Upper fauna. Mollusca

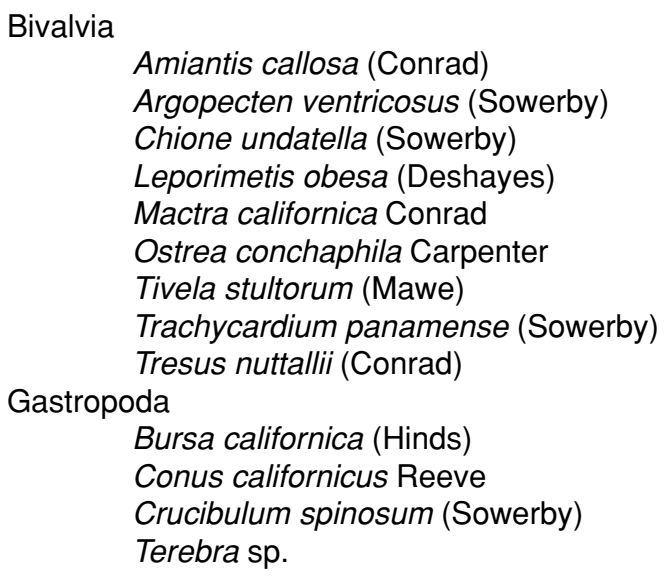

LACMIP 4560. Label reads “... at bottom of Coyote Creek, E of Highway 39 [Beach Blvd.], N of Rosecranz Ave., near LA-Orange Co. line. Collected G. L. Paul, 2/10/65.” Middle fauna. Mollusca Bivalvia Patinopecten caurinus (Gould)

LACMIP 6210. (=LACMV 5011). Elevation between $64 \mathrm{~m}$ (210') and $65.6 \mathrm{~m}$ (215') in a 25-cm thick, poorly sorted, silty to medium-grained arkosic to subarkosic, biotitic, very friable sandstone. Located approximately 4-5 m stratigraphically below LACMIP 6211 (=LACMV 5012) and approximately $17 \mathrm{~m}$ stratigraphically below the base of the overlying Coyote Hills Formation. NE1/4, SE1/4, NW1/4, SW1/4, NE1/4 of section 24, T. 3 S., R. 11 W. La Habra 7.5' Quadrangle. Fullerton, Orange County, CA. Diana Weir and Marilyn Morgan, collectors. Upper fauna.

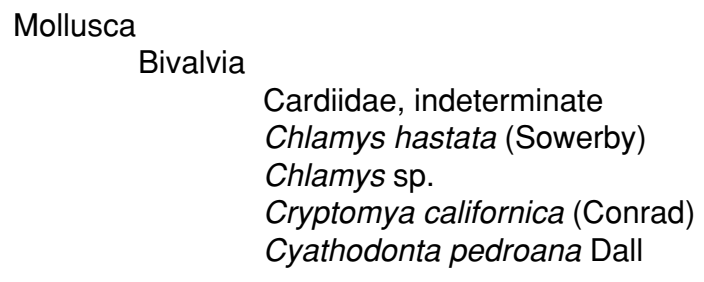




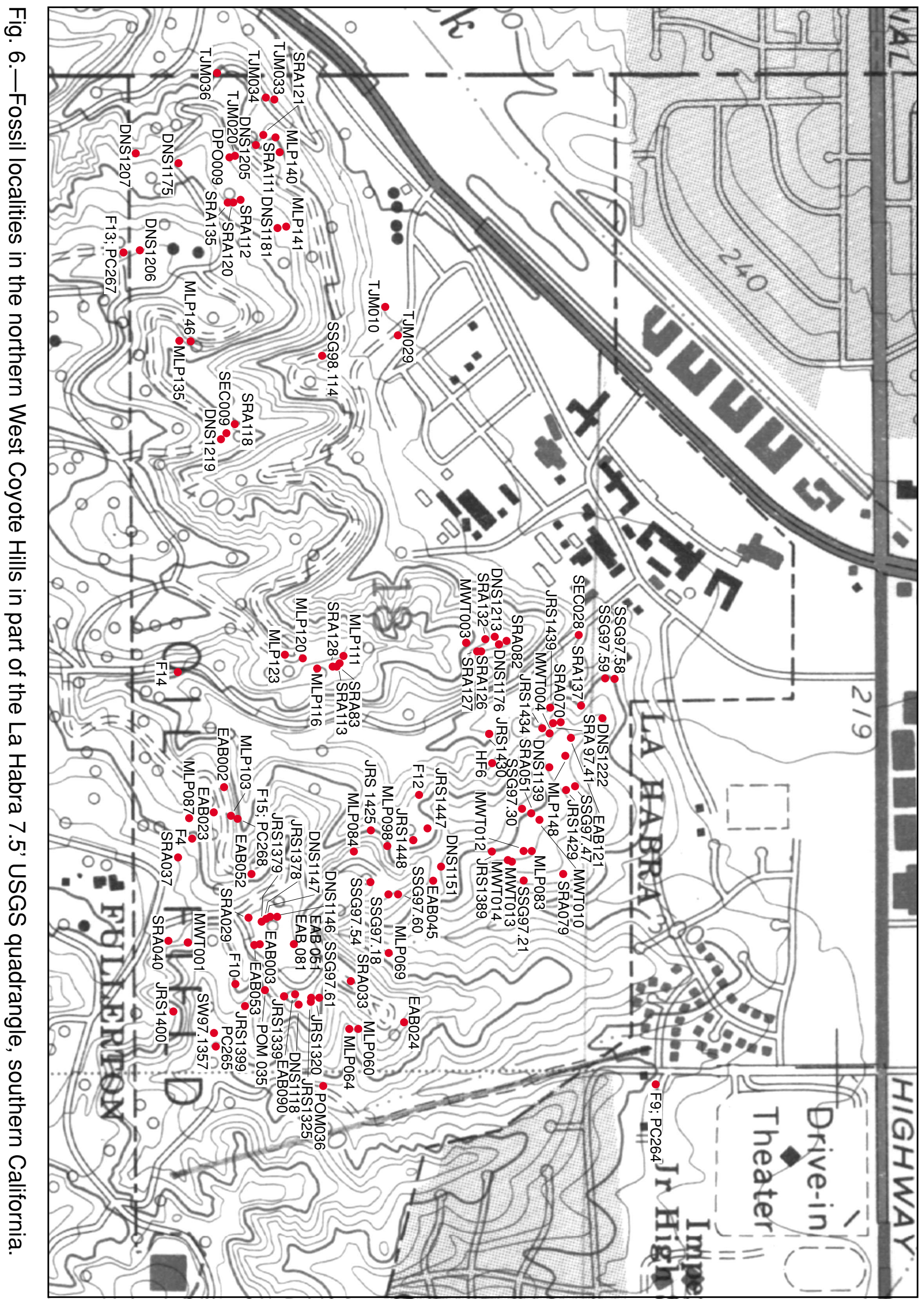




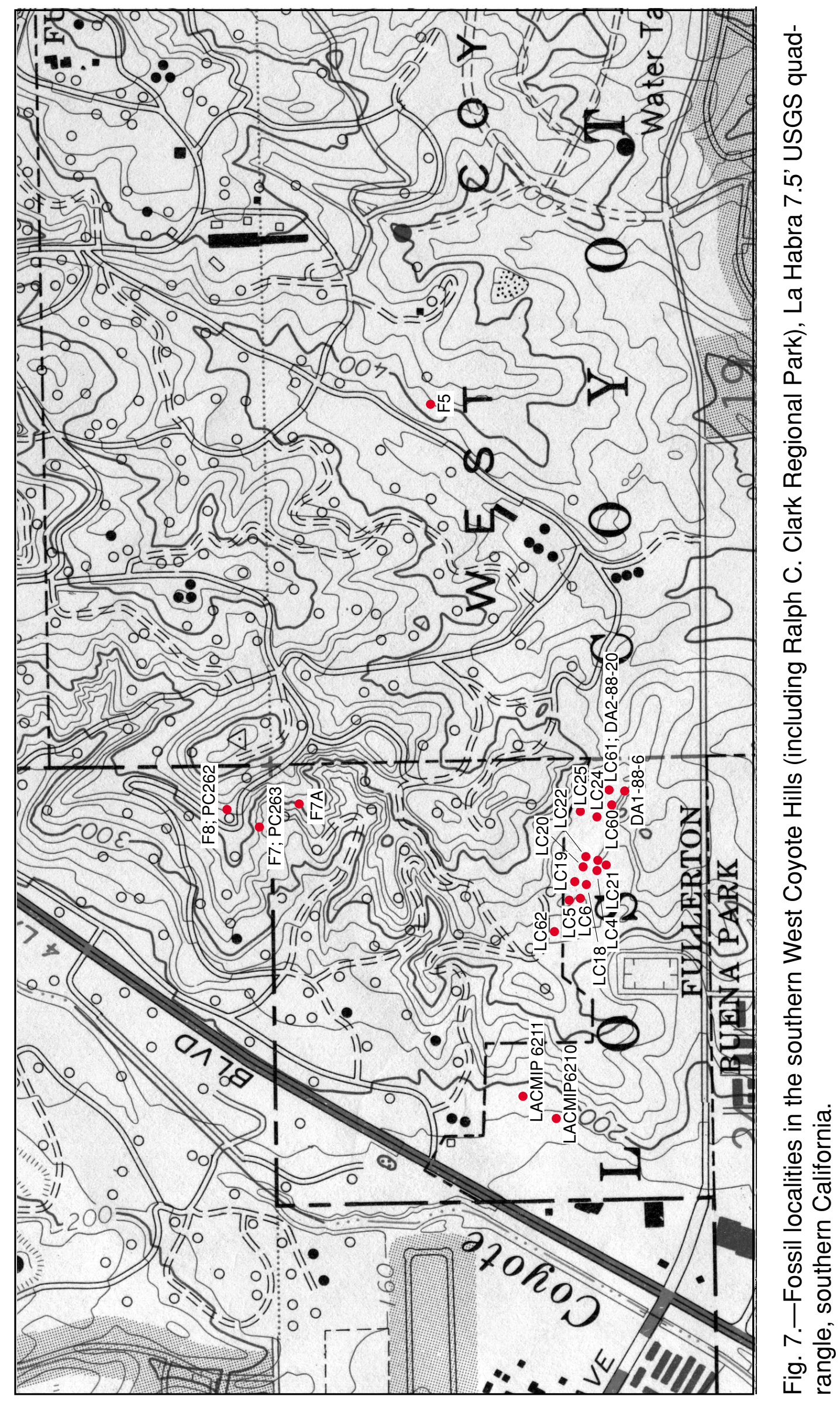

USGS Open-file Report 00-319, page 37 


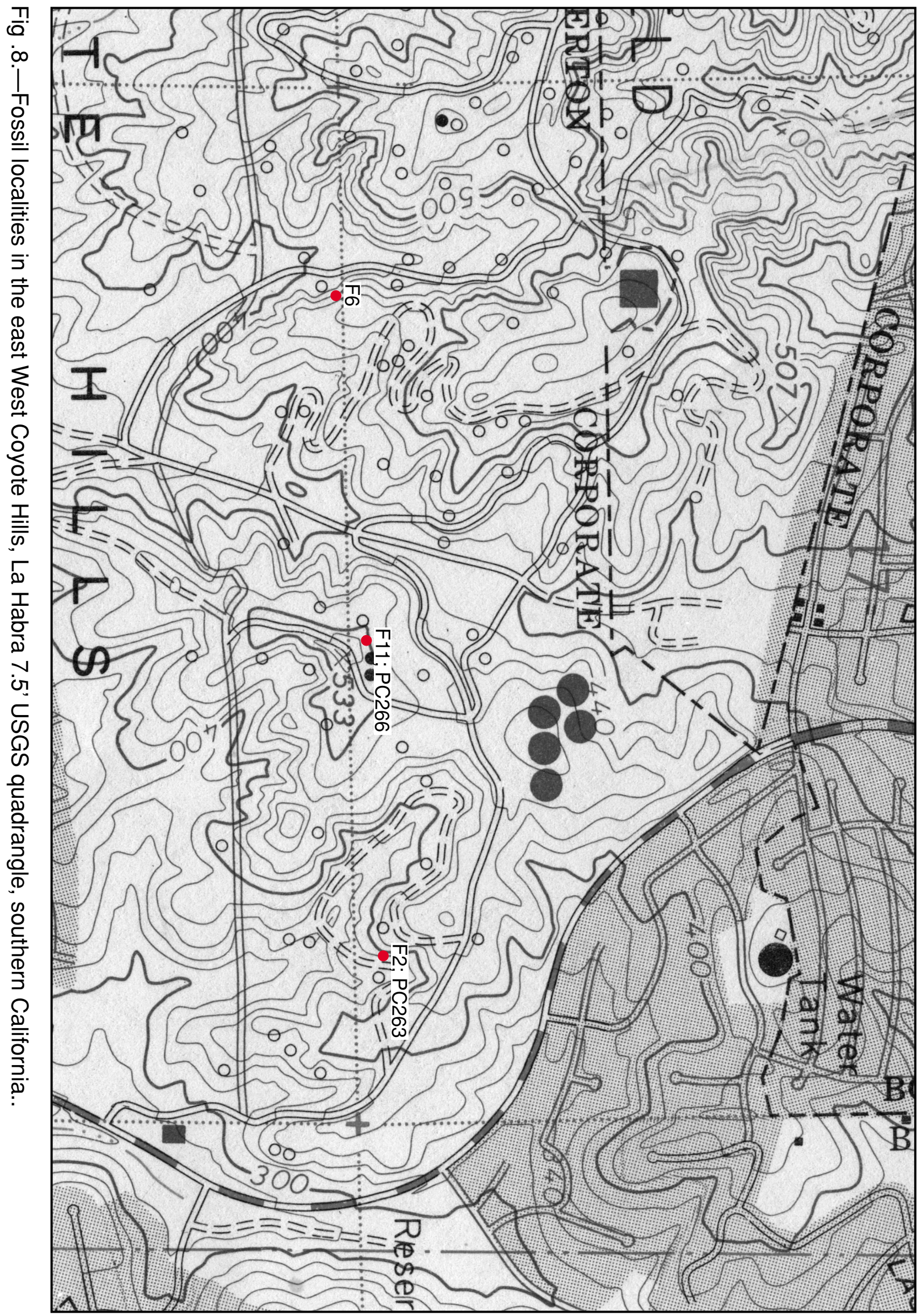




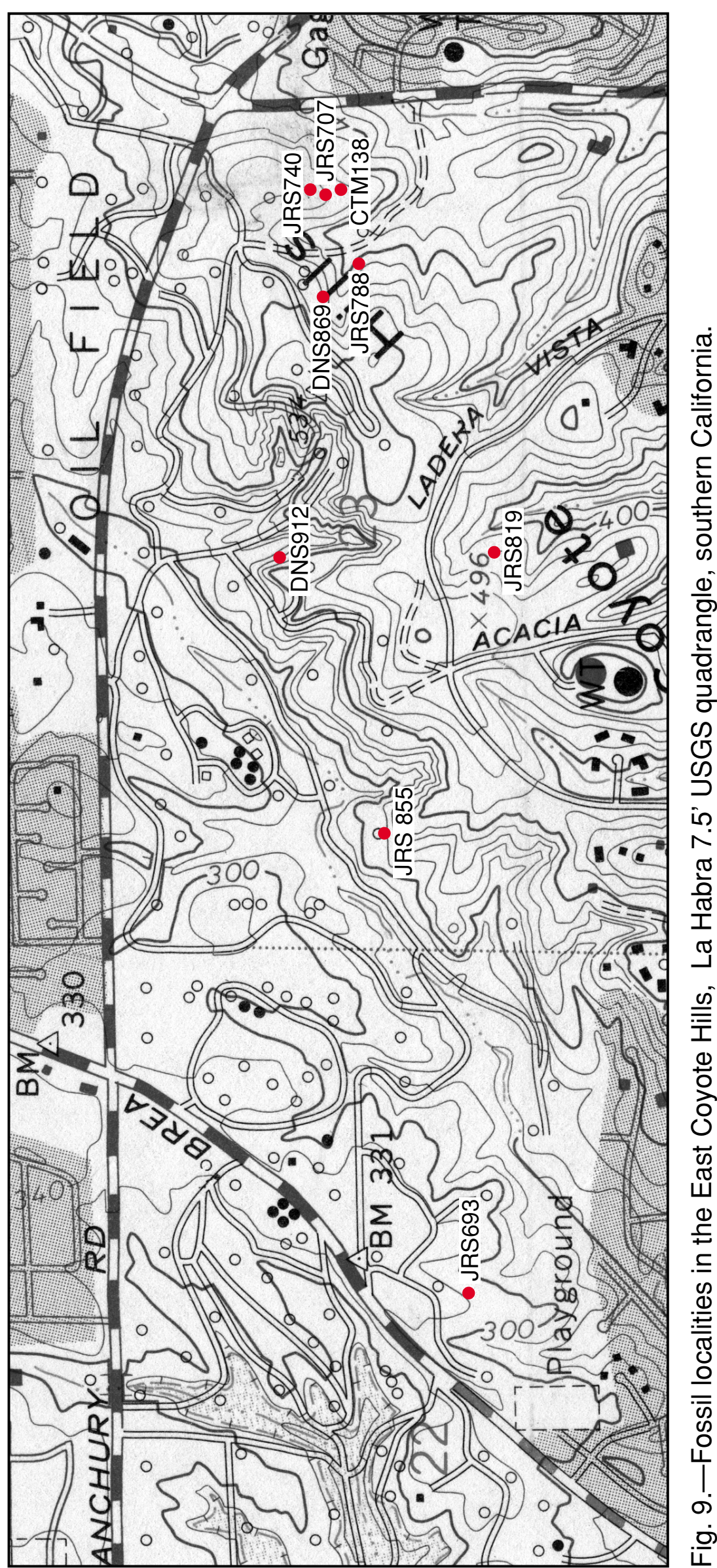

USGS Open-file Report 00-319, page 39 


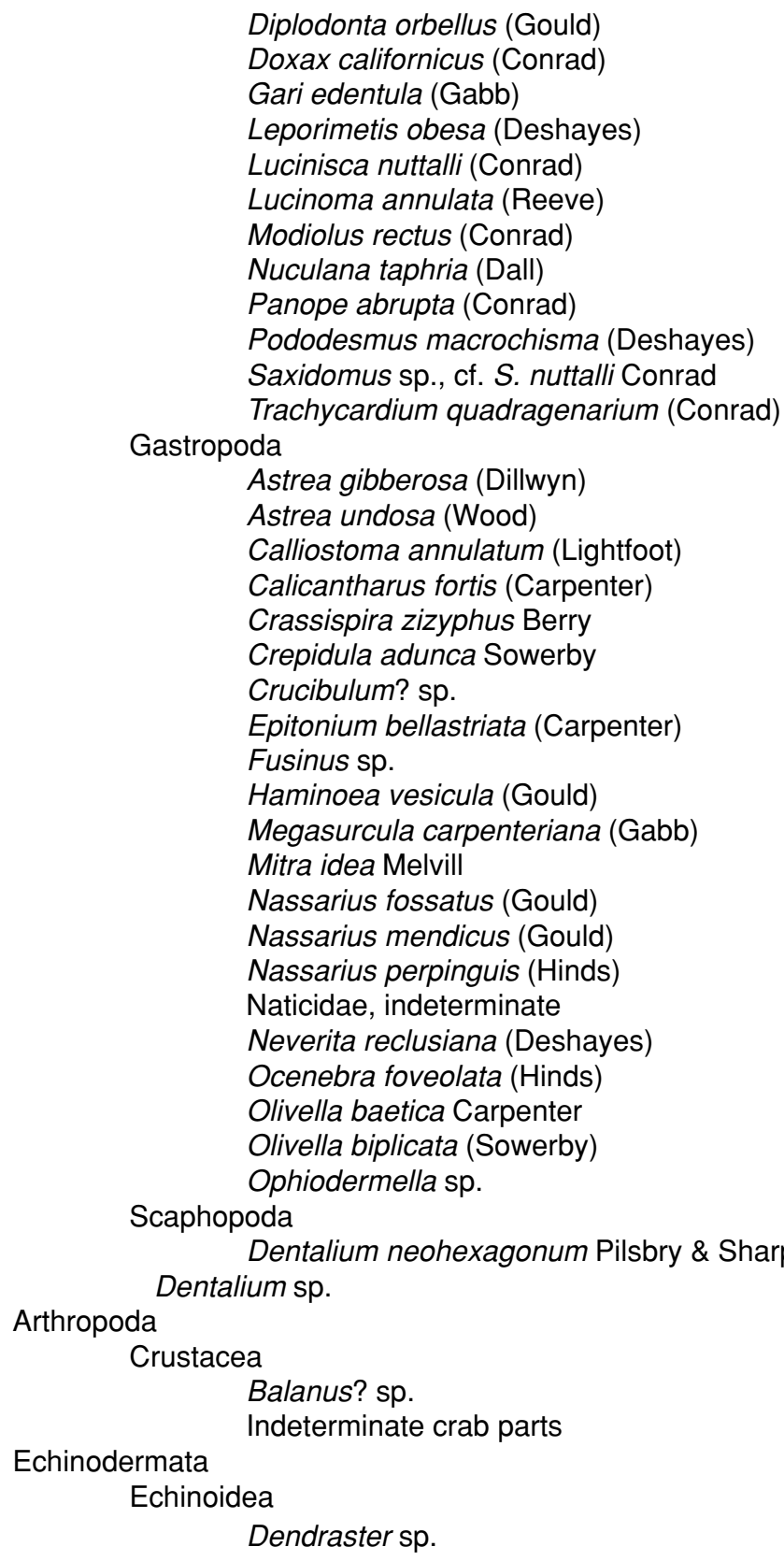

Dendraster sp.

LACMIP 6211 (=LACMV 5012). Situated at an elevation between $68 \mathrm{~m}$ (222') and $73 \mathrm{~m}$ (240') above sea level is a $0.6 \mathrm{~m}$ (2-foot) thick, poorly sorted, pebble conglomerate with numerous articulated, disarticulated and fragmented mollusk shells, about $12 \mathrm{~m}$ to $13 \mathrm{~m}$ below the base of the overlying Coyote Hills Formation. NE1/4, SE1/4, NW1/4, SW1/4, NE1/4 of section 24, T. 3 S., R. 11 W. La Habra 7.5' Quadrangle. Fullerton, Orange County, CA. Diana Weir and Marilyn Morgan, ollectors. Upper fauna (?).

Mollusca Bivalvia

Cardiidae, indeterminate

Chlamys hastata (Sowerby)

Chlamys sp.

Compsomyax subdiaphana (Carpenter)?

Crassadoma giganteus (Gray)

Leporimetis? sp.

Leptopecten latiauratus (Conrad)

Lithophagidae, indeterminate

Lucinisca nuttalli (Conrad)

Lucinidae, indeterminate 


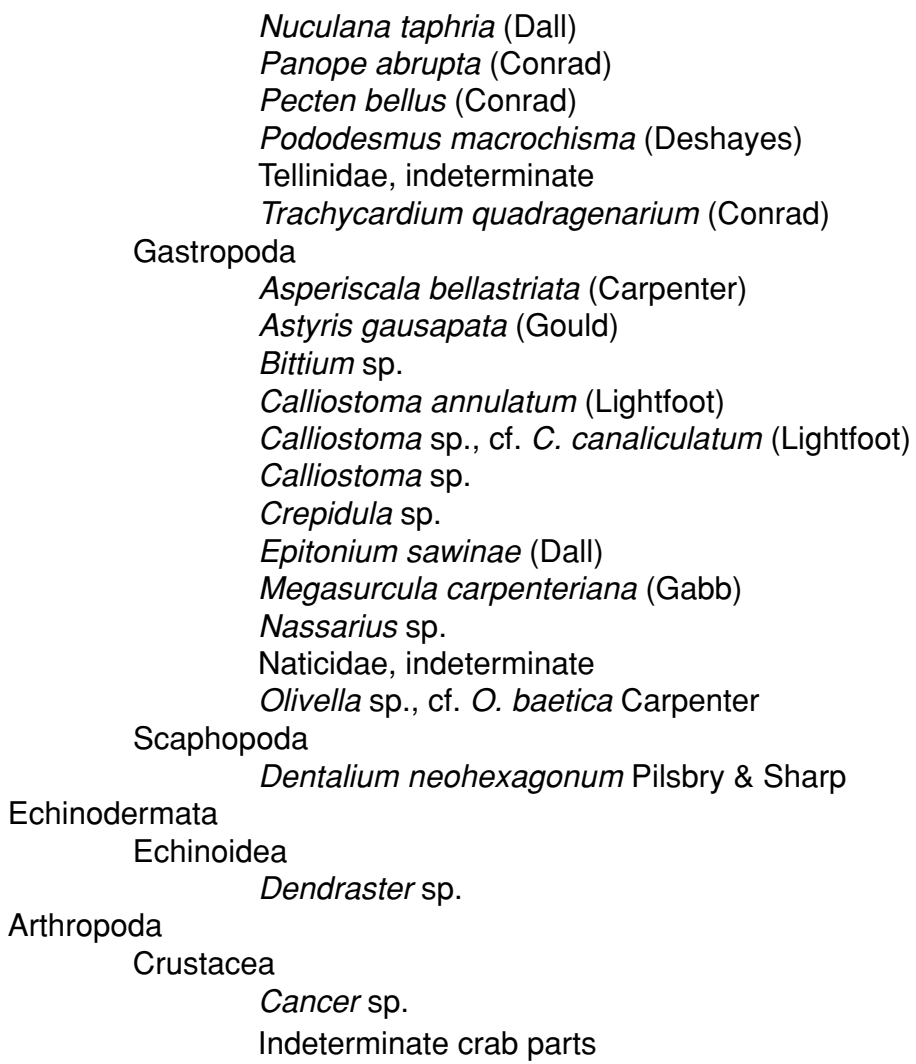

Ralph B. Clark Regional Park

Field No.: LC-1. Striatgraphic position uncertain; but sample probably collected from lower bluff behind baseball diamonds across Rosecrans Blvd. from Ralph B. Clark Regional Park headquarters, 8800

Rosecrans Blvd., Buena Park, Orange County, CA. Collector unknown.

Mollusca

Gastropoda

Astrea sp.

Field No.: LC-4. Located $30 \mathrm{~m}$ to $52 \mathrm{~m}$ below contact between Coyote Hills Formation and "San Pedro" Formation in lower bluff behind baseball diamonds across Rosecrans Blvd. from Ralph B. Clark Regional Park headquarters, 8800 Rosecrans Blvd., Buena Park, Orange County, CA. Collector unknown. Middle fauna.

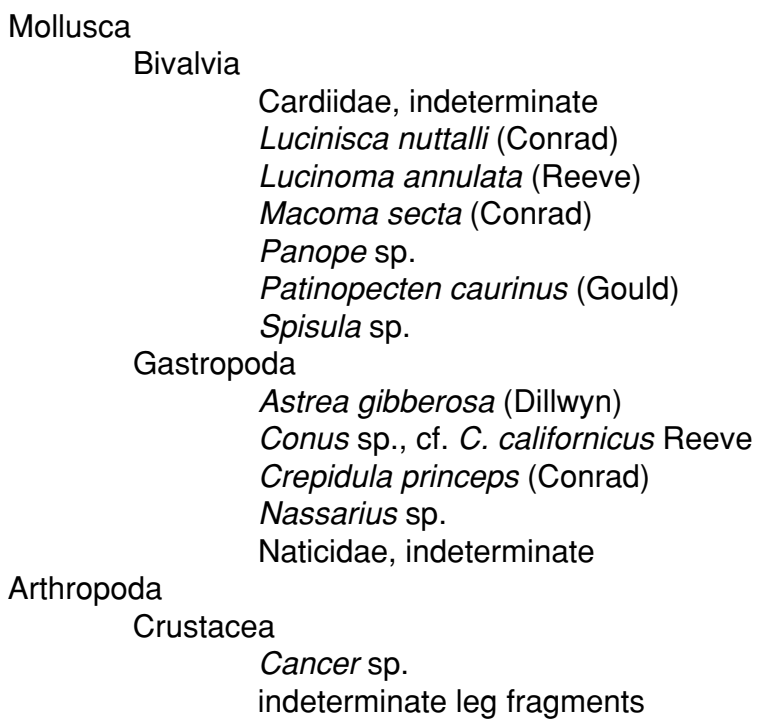


Field No.: LC-5. Located $30 \mathrm{~m}$ to $52 \mathrm{~m}$ below contact between Coyote Hills Formation and "San Pedro" Formation in lower bluff behind baseball diamonds across Rosecrans Blvd. from Ralph B. Clark Regional Park headquarters, 8800 Rosecrans Blvd., Buena Park, Orange County, CA. Collector unknown.

Echinodermata

Echinoidea

Dendraster venturaensis Kew

Field No.: LC-6. Located $30 \mathrm{~m}$ to $52 \mathrm{~m}$ below contact between Coyote Hills Formation and "San Pedro" Formation in lower bluff behind baseball diamonds across Rosecrans Blvd. from Ralph B. Clark Regional Park headquarters, 8800 Rosecrans Blvd., Buena Park, Orange County, CA. Collector unknown.

Mollusca

Bivalvia

Gastropoda

Modiolus? sp.

Arthropoda

Neptunea tabulata (Baird)

Crustacea

Cancer sp.

Field No.: LC-18. Located $30 \mathrm{~m}$ to $52 \mathrm{~m}$ below contact between Coyote Hills Formation and "San Pedro" Formation in lower bluff behind baseball diamonds across Rosecrans Blvd. from Ralph B. Clark Regional Park headquarters, 8800 Rosecrans Blvd., Buena Park, Orange County, CA. Collector unknown.

Mollusca

Bivalvia

Cardiidae, indeterminate

Mytilus californianus Conrad

Gastropoda

Tresus nuttalli (Conrad)

Arthropoda

Calliostoma sp. cf. C. variegatum Carpenter

Balanus sp.

Field No.: LC-19. Located $30 \mathrm{~m}$ to $52 \mathrm{~m}$ below contact between Coyote Hills Formation and "San Pedro" Formation in lower bluff behind baseball diamonds across Rosecrans Blvd. from Ralph B. Clark Regional Park headquarters, 8800 Rosecrans Blvd., Buena Park, Orange County, CA. Collector unknown.

Echinodermata

Echinoidea

Dendraster venturaensis Kew

Field No.: LC-20. Located $30 \mathrm{~m}$ to $52 \mathrm{~m}$ below contact between Coyote Hills Formation and "San Pedro" Formation in lower bluff behind baseball diamonds across Rosecrans Blvd. from Ralph B. Clark Regional Park headquarters, 8800 Rosecrans Blvd., Buena Park, Orange County, CA. Collector unknown. Identified by C. Powell, II

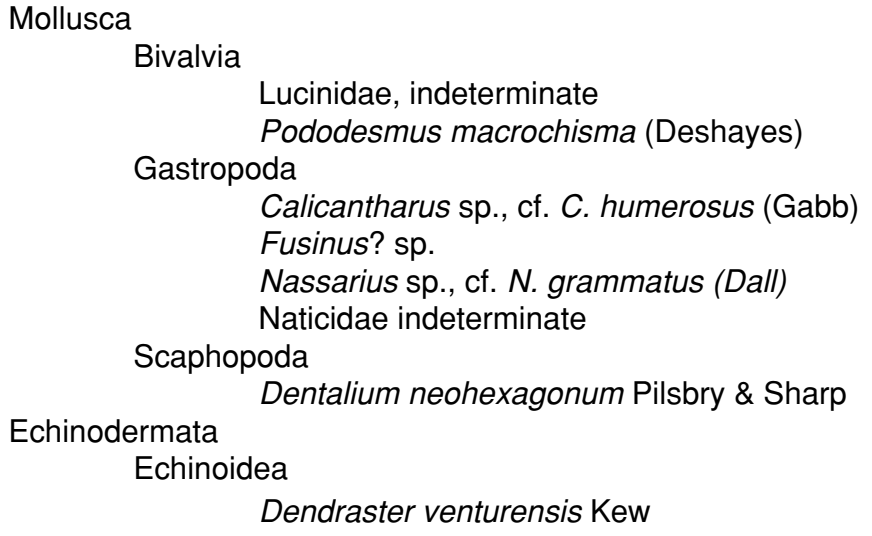

Dendraster venturensis Kew 
Field No.: LC-21. Sample collected between $52 \mathrm{~m}$ and $54 \mathrm{~m}$ below Coyote Hills Formation and "San Pedro" Formation boundary in lower bluff behind baseball diamonds across Rosecrans Blvd. from Ralph B. Clark Regional Park headquarters, 8800 Rosecrans Blvd., Buena Park, Orange County, CA. Collector unknown. Upper fauna (?).

Mollusca

Bivalvia

Cardiidae, indeterminate

Chlamys hastata (Sowerby)

Crassinella? sp.

Lucinisca nuttalli (Conrad)

Lucinoma annulata (Reeve)

Macoma nasuta (Conrad)

Macoma secta (Cornad)

Macoma sp.

Modiolus rectus (Conrad)

Nuculana taphria (Dall)

Nuculana sp.

Nutricola tantilla (Gould)?

Ostrea conchaphila Carpenter

Panope abrupta Conrad

Protothaca? sp.

Solen sp.

Teredinidae, indeterminate

Gastropoda

Tresus nuttalli (Conrad)

Acteocina sp., cf. culcitella (Gould)

Acteocina sp.

Astrea sp.

Astyris gausapata (Gould)

Boreotrophon? sp.

Calliostoma sp.

Calliostoma sp. cf. C. variegatum Carpenter

Conus californicus Reeve

Crepidula sp., cf. C. adunca Sowerby

Crepidula sp., cf. C. princeps (Conrad)

Crockerella? sp.

Epitonium sawinae (Dall)

Fusinus? sp.

Homalopoma paucicostatum (Dall)

Lacuna sp., cf. L. unifasciata Carpenter

Lirobittium sp., cf. L. lomaense (Bartsch)

Nassarius sp., cf. N. grammatus (Dall)

Nassarius sp.

Naticidae indeterminate

Neptunea tabulata (Baird)

Neverita reclusiana (Deshayes)?

Ocenebra sp., cf. O. foveolata (Hinds)

Olivella sp., cf. O. baetica Carpenter

Olivella sp., cf. O. biplicata (Sowerby)

Opalia borealis Keep

Polinices lewisii (Gould)

Turbonilla sp.

Scaphopoda

Turridae, indeterminate

Dentalium neohexagonum Pilsbry \& Sharp

Dentalium sp.

Arthropoda

Crustacea

Cancersp.

crab leg fragments

Coronulidae, indeterminate (whale barnacles)

Echinodermata 
Echinoidea

Dendraster venturaensis Kew

Indeterminate echinoid spines

Field No.: LC-22. Located $30 \mathrm{~m}$ to $52 \mathrm{~m}$ below contact between Coyote Hills Formation and "San Pedro" Formation in lower bluff behind baseball diamonds across Rosecrans Blvd. from Ralph B. Clark Regional Park headquarters, 8800 Rosecrans Blvd., Buena Park, Orange County, CA. Collector unknown.

Mollusca

Bivalvia

Chlamys sp., cf. C. hastata (Sowerby)

Chlamys sp., cf. C. rubida (Hinds)

Chlamys sp.

Gastropoda

Pododesmus macrochisma (Deshayes)

Cantharus sp.

Conus sp., cf. C. californicus Reeve

Nassarius sp.

Naticidae indeterminate

Neptunea tabulata (Baird)

Olivella sp.

Field No.: LC-24. Located $30 \mathrm{~m}$ to $52 \mathrm{~m}$ below contact between Coyote Hills Formation and "San Pedro" Formation in lower bluff behind baseball diamonds across Rosecrans Blvd. from Ralph B. Clark Regional Park headquarters, 8800 Rosecrans Blvd., Buena Park, Orange County, CA. Collector unknown.

Mollusca

Bivalvia

Chlamys rubida (Hinds)

Pododesmus? sp.

Field No.: LC-25. Located $30 \mathrm{~m}$ to $52 \mathrm{~m}$ below contact between Coyote Hills Formation and "San Pedro" Formation in lower bluff behind baseball diamonds across Rosecrans Blvd. from Ralph B. Clark Regional Park headquarters, 8800 Rosecrans Blvd., Buena Park, Orange County, CA. Collector unknown.

Mollusca

Bivalvia

Pododesmus sp.

Field No.: LC-60. Sample collected between $78.5 \mathrm{~m}$ and $78.85 \mathrm{~m}$ below Coyote Hills Formation and "San Pedro" Formation boundary in lower bluff behind baseball diamonds across Rosecrans Blvd. from Ralph B. Clark Regional Park headquarters, 8800 Rosecrans Blvd., Buena Park, Orange County, CA. Collector unknown. Middle fauna.

Mollusca

Bivalvia

Patinopecten caurinus (Gould)

Field No.: LC-62. Located 2 m to 32 m below contact between Coyote Hills Formation and "San Pedro" Formation in lower bluff behind baseball diamonds across Rosecrans Blvd. from Ralph B. Clark Regional Park headquarters, 8800 Rosecrans Blvd., Buena Park, Orange County, CA. Collector unknown. Mollusca Bivalvia

Chlamys sp., cf. C. hastata (Sowerby)

Field No.: LC-68. Stratgraphic position uncertain, but sample probably collected from lower bluff behind baseball diamonds across Rosecrans Blvd. from Ralph B. Clark Regional Park headquarters, 8800 Rosecrans Blvd., Buena Park, Orange County, CA. Collector unknown. Mollusca Gastropoda

Haliotis sp., cf. H. cracherodii Leach 
Field No.: LC-83. Stratgraphic position uncertain, but sample probably collected from lower bluff behind baseball diamonds across Rosecrans Blvd. from Ralph B. Clark Regional Park headquarters, 8800

Rosecrans Blvd., Buena Park, Orange County, CA. Collector unknown. Middle fauna (?).

Mollusca

Bivalvia

Patinopecten sp.

Field No.: LC-84. Stratgraphic position uncertain, but sample probably collected from lower bluff behind baseball diamonds across Rosecrans Blvd. from Ralph B. Clark Regional Park headquarters, 8800

Rosecrans Blvd., Buena Park, Orange County, CA. Collector unknown.

Mollusca

Bivalvia

Pododesmus sp.

Echinodermata

Echinoidea

Dendraster venturaensis Kew

Field No.: LC-85. Stratigraphic position uncertain, but sample probably in the upper $50 \mathrm{~m}$ of "San Pedro" Formation in lower bluff behind baseball diamonds across Rosecrans Blvd. from Ralph B. Clark Regional Park headquarters, 8800 Rosecrans Blvd., Buena Park, Orange County, CA. Collector unknown. Middle fauna.

Mollusca Bivalvia

Patinopecten caurinus (Gould)

Field No.: DA-1-88-6. Sample collected between $82.35 \mathrm{~m}$ and $83.35 \mathrm{~m}$ below Coyote Hills Formation and "San Pedro" Formation boundary in lower bluff behind baseball diamonds across Rosecrans Blvd. from Ralph B. Clark Regional Park headquarters, 8800 Rosecrans Blvd., Buena Park, Orange County, CA. Collector unknown.

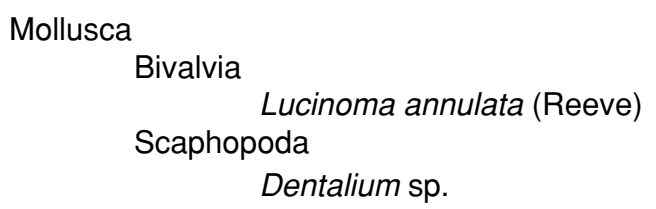

Field No.: DA-2-88-20 Sample collected between $79.85 \mathrm{~m}$ and $82.35 \mathrm{~m}$ below Coyote Hills Formation and "San Pedro" Formation boundary in lower bluff behind baseball diamonds across Rosecrans Blvd. from Ralph B. Clark Regional Park headquarters, 8800 Rosecrans Blvd., Buena Park, Orange County, CA. Collector unknown. Middle fauna.

Mollusca

Bivalvia

Patinopecen caurinus (Gould)

Field No.: ULH 88-2. Stratigraphic position uncertain, but sample probably collected from lower bluff behind baseball diamonds across Rosecrans Blvd. from Ralph B. Clark Regional Park headquarters, 8800

Rosecrans Blvd., Buena Park, Orange County, CA. Collector unknown. Middle fauna (?) Mollusca

Bivalvia

Cardiidae, indeterminate

Chlamys sp.

Lucinoma annulata (Reeve)

Lucinisca nuttalli (Conrad)

Macoma nasuta(Conrad)?

Macoma secta (Conrad)

Nuculana sp.

Pandora sp.

Gastropoda

Patinopecten sp.

Astyris gausapata (Gould) 


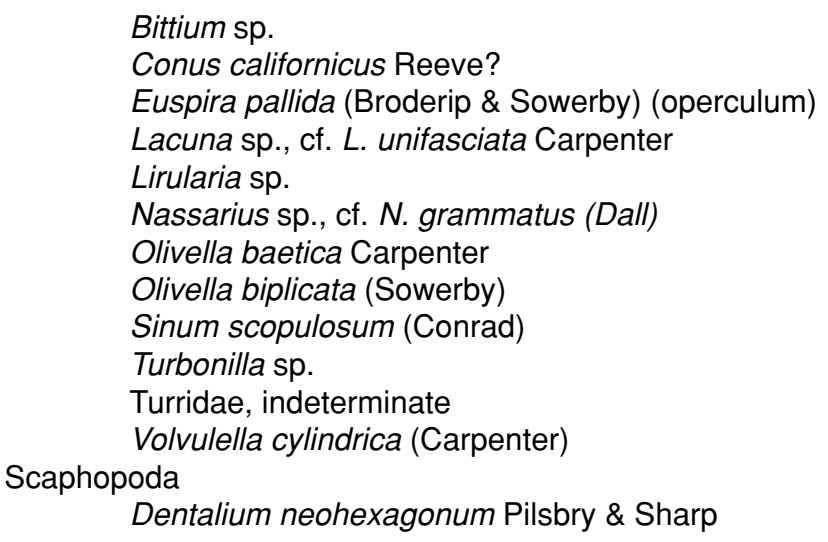

Field No.: Float. Stratigraphic position uncertain, but sample collected from lower bluff behind baseball diamonds across Rosecrans Blvd. from Ralph B. Clark Regional Park headquarters, 8800 Rosecrans Blvd., Buena Park, Orange County, CA. Collector unknown.

Arthropoda

Crustacea

Randallia ornata (Randall)

Claremont College, Department of Geology [Also referred to as Pomona College. These are the collections from Hoskins (1954) thesis. Unfortunately when examined in the summer of 1999, several boxes appear to be missing. The boxes present were numbered 4 to 9].

PC 262. Locality description from Hoskins (1954). " $10,000^{\prime}$ north and 7,200' $E$ of intersection of 118 $00^{\prime}$ ' W longitude and $33^{\circ} 52^{\prime} 30^{\prime \prime} \mathrm{N}$ latitude at an elevation of 375'. Coyote Hills silt in cut for Emery \#79", Coyote Hills, Orange County, CA. Collected by Cortez Hoskins, circa. early 1950's, field no. 1. Middle fauna.

Mollusca

Bivalvia

Chlamys hastata (Sowerby)

Compsomyax subdiaphana (Carpenter)

Cyathodonta sp., cf. C. pedroana Dall

Cyclocardia sp., aff. C. occidentalis (Conrad) of Woodring and others

Mytilus trossulus Gould

Pandora wardiana Adams

Saxidomus nuttalli Conrad

Solamen sp., cf. S. columbianum (Dall)

Solen sp., cf. S. sicarius Gould

Gastropoda

Thracia sp.

Lirobittium sp.

Neptunea tabulata (Baird)

Olivella biplicata (Sowerby)

PC 263. Locality description from Hoskins (1954). "About 250' SW of F1 and about 40' higher in cut for Emery \#65. In transition zone," Coyote Hills, Orange County, CA. Collected by Cortez Hoskins, circa. early 1950's, field no. 2. Middle fauna.

Mollusca

Bivalvia

Lucinoma annulata (Reeve)

Mytilus trossulus Gould

Nutricola sp.

Pandora sp.

Panope sp.

Patinopecten caurinus (Gould)

Solen sp.

Thracia sp.

Trachycardium quadragenarium (Conrad)

Gastropoda

Crepidula princeps Conrad 
PC 264. Locality description from Hoskins (1954). " 14,100 ' $\mathrm{N}$ and 12,750' $\mathrm{E}$ of same reference point at an elevation of about 285'. In San Pedro Sand (?)", Coyote Hills, Orange County, CA. Collected by Cortez Hoskins, circa. early 1950's, field no. 3. Upper fauna.

Mollusca

Bivalvia

Argopecten sp.

Chione sp., cf. C. californiensis (Broderip)

Chlamys sp., cf. C. anapleus Woodring

Cryptomya californica (Conrad)

Donax gouldii Dall

Glycymeris septentrionalis Middendorff

Leporimetis obesa (Deshayes)

Leptopecten latiauratus (Conrad)

Lucinisca nuttalli Conrad

Macoma indentata Carpenter

Macoma secta (Conrad)

Mactromeris hemphillii (Dall)

Modiolus sp.

Ostrea conchaphila (Carpenter)

Pandora sp., cf. P. punctata Conrad

Panope abrupta (Conrad)

Parvilucina sp., cf. P. approximata (Dall)

Periploma planiusculum Sowerby

Protothaca tenerrima (Carpenter)

Spisula sp., cf. S. catilliformis Conrad

Tivela stultorum (Mawe)

Trachycardium quadragenarium (Conrad)

Gastropoda

Tresus nuttallii (Conrad)

Acanthina spirata (Blainville)

Acteocina sp.

Alia carinata (Hinds)

Balcis sp.

Bursa califronica (Hinds)

Cancellaria fergusoni Carson

Conus californicus Reeve

Crassispira zizyphus Berry

Crepidula sp.

Crucibulum spinosum (Sowerby)

Cryptonatica affinis (Gmelin)

Epitonium sp.

Erato vitellina Hinds

Globodrilla hemphilli (Stearns)

Lacuna unifasciana Carpenter

Littorina sp.

Mitrella sp.

Nassarius sp., cf. N. cerritensis (Arnold)

Nassarius fossatus (Gould)

Nassarius sp., cf. N. insculpta (Carpenter)

Nassarius sp., cf. N. mendicus (Gould)

Naticidae, indeterminate

Neptunea tabulata (Baird)

Neverita reclusiana (Deshayes)

Olivella baetica Carpenter

Olivella biplicata (Sowerby)

Ophiodermella? sp.

Terebra danai Berry

Turridae, indeterminate

Scaphopoda

Volvarina? sp.

Dentalium neohexagonum (Pilsbry \& Sharp)

Dentalium sp. 


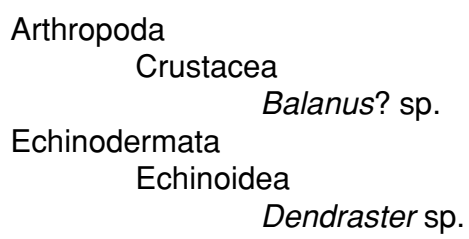

PC 265. Locality description from Hoskins (1954). " 11,950 ' $\mathrm{N}$ and 12,450' E of reference point at an elevation of 430'. In San Pedro Sand (?)", Coyote Hills, Orange County, CA. Collected by Cortez Hoskins, circa. early 1950's, field no. 4. Upper fauna (?).

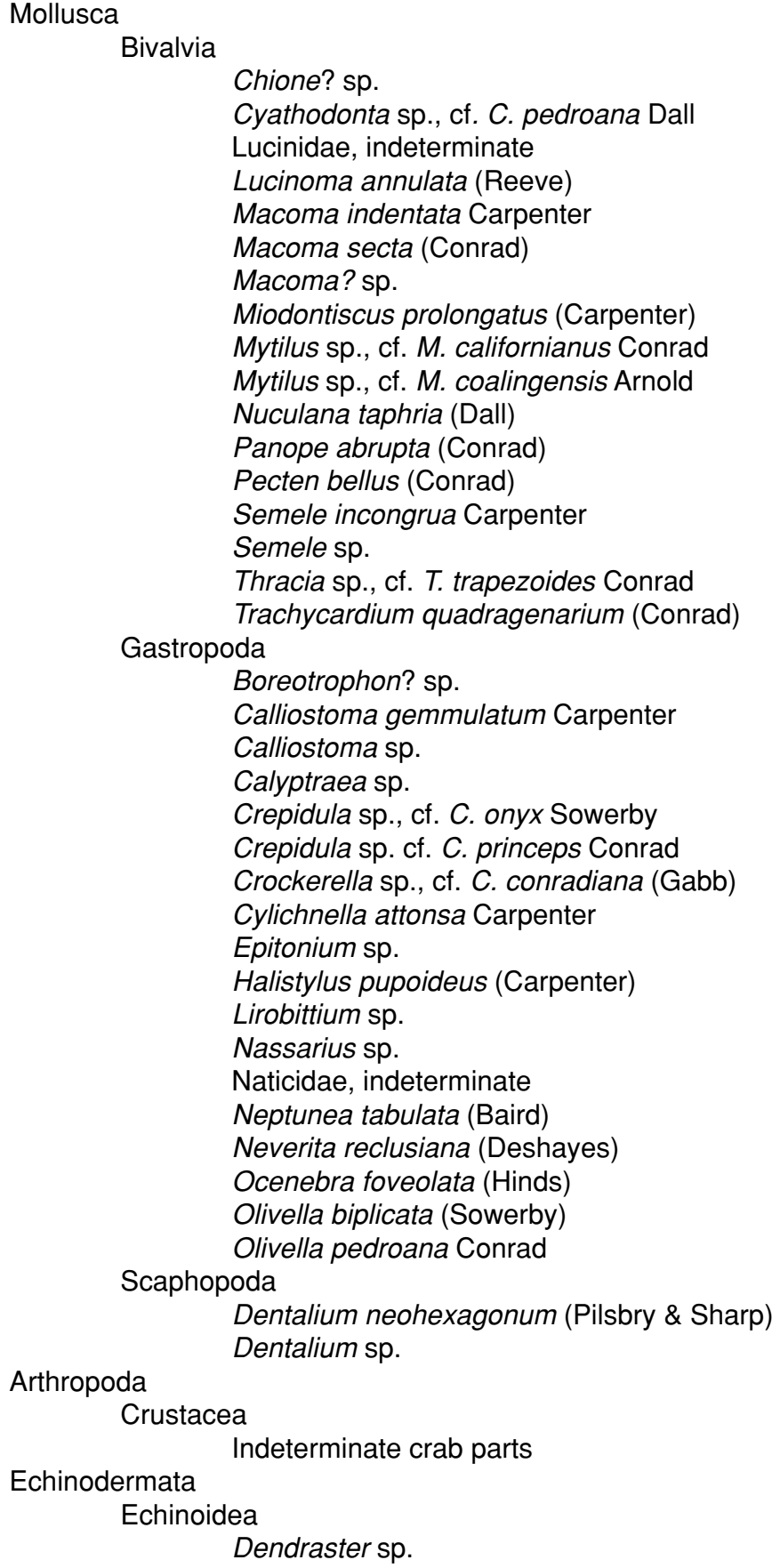

Dendraster sp. 
PC 266. Locality description from Hoskins (1954). "10,150' $N$ and 15,500' E of reference point at an elevation of 500'. In San Pedro Sand (?)", Coyote Hills, Orange County, CA. Collected by Cortez Hoskins, circa. early 1950's, field no. 5.

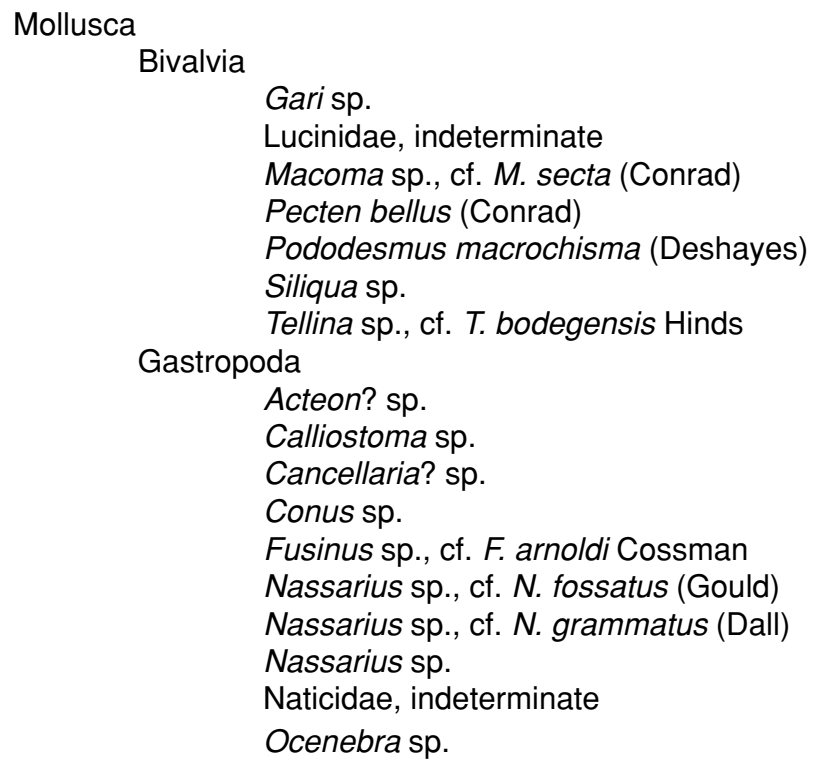

No PC number. Locality description from Hoskins (1954). “13,000' $N$ and 11,250' E of reference point at an elevation of 400'. In San Pedro Sand (?)", Coyote Hills, Orange County, CA. Collected by Cortez Hoskins, circa. early 1950's, field no. 6.

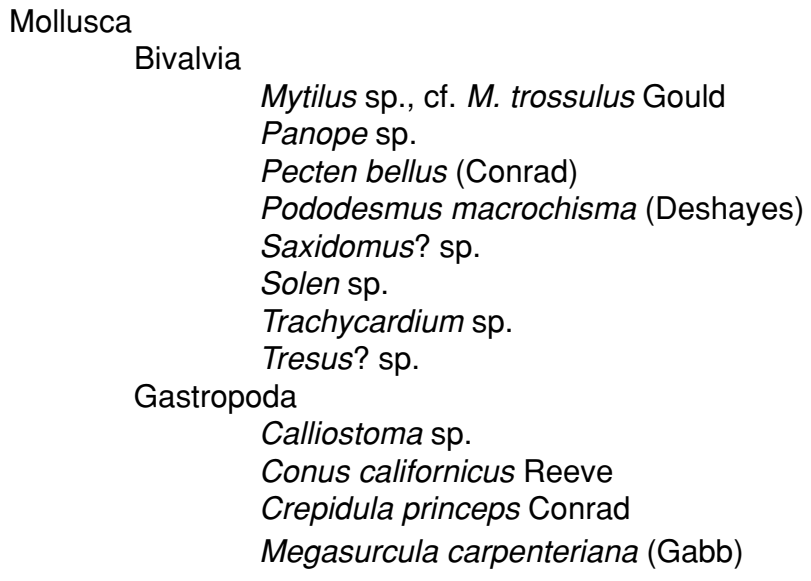

No PC number. Locality description from Hoskins' (1954) thesis. " 10.250 ' $\mathrm{N}$ and 17,100' E of reference point at an elevation of 380'. In San Pedro Sand (?)", Coyote Hills, Orange County, CA. Collected by Cortez Hoskins, circa. early 1950's, field no. 7.

Mollusca

$$
\text { Bivalvia }
$$

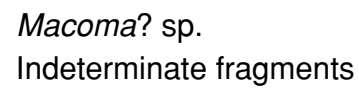

PC 267. Locality description from Hoskins (1954). "11,300' $N$ and 8,900' $E$ of reference point at an elevation of 500'. In San Pedro Sand (?)", Coyote Hills, Orange County, CA. Collected by Cortez Hoskins, circa. early 1950's, field no. 8. Middle fauna.

Mollusca

Bivalvia

Chlamys sp., cf. C. behringiana (Middendorff)

Compsomyax subdiaphana (Carpenter)

Cyclocardia sp., aff. C. occidentalis (Conrad) of Woodring and others 


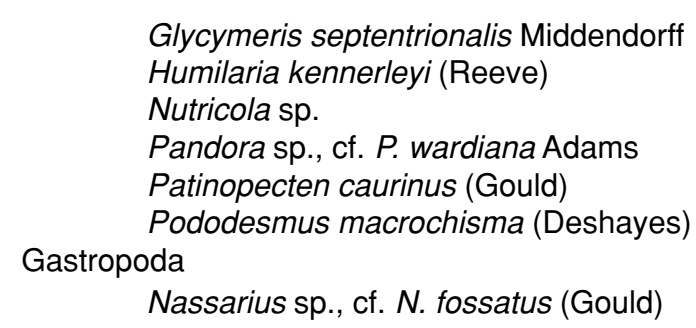

PC 268. Locality description from Hoskins (1954). “ 11,800 ' $\mathrm{N}$ and 11,250' E of reference point at an elevation of 475'. In San Pedro Sand (?) about 300' W of F4", Coyote Hills, Orange County, CA. Collected by Cortez Hoskins, circa. early 1950's, field No. F10.

Mollusca

Bivalvia

Gastropoda

Veneridae, indeterminate

Crepidula princeps Conrad

Fusinus sp., cf. F. arnoldi Cossman

Turritella sp.

RMW Paleo Associates RMW Paleo Associates fossil localities can be located on Figure 6 for the north West Coyote Hills and Figure 9 for the East Coyote Hills.

Map measurements are $\pm 0.4 \mathrm{~km}$; section measurements are $\pm 2 \mathrm{~m}$.

Field No.: RMW/CTM 138. "Fine grained silt. Coyote Hills Formation. Location: Grisalli cut, south and below restaurant on ridge, elevation 395' [120 m]." Locality located in former oil field about $0.24 \mathrm{~km} \mathrm{SW}$ of intersection of State College Blvd. and Bastanchury Rd., East Coyote Hills, Fullerton, Orange County, CA. Site stratigraphically about $8 \mathrm{~m}$ above base of exposed "San Pedro" Formation. Collected by Chris Morgan, 6/10/94.

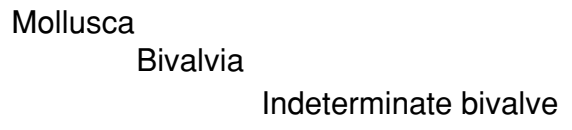

Field No.: RMW/DNS 869. "Sandstone concretion. San Pedro Formation. Location: large cut facing State College, elevation 442'." Locality located in former oil field about $0.36 \mathrm{~km} \mathrm{SW}$ of intersection of State College Blvd. and Bastanchury Rd. and $0.14 \mathrm{~km}$ ESE of triangulation station 543, East Coyote Hills, Fullerton, Orange County, CA. Site stratigraphically about $6 \mathrm{~m}$ above base of exposed "San Pedro" Formation. Collected by David Stevens, 7/12/94. Lower fauna (?).

Annelida

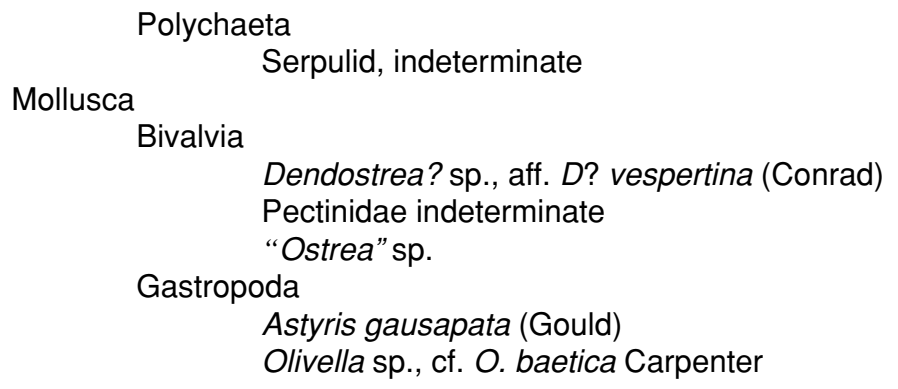

Field No.: RMW/DNS 1118. "Tan oxidized siltstone and sand. San Pedro Formation. Location: next to well MC259, elevation 345' [105 m]." Locality located in former oil field about $0.96 \mathrm{~km}$ S of Imperial Highway 0.71 $\mathrm{km}$ E of its intersection with Beach Blvd. and $1.18 \mathrm{~km} \mathrm{SE}$ of intersection of Beach Blvd and Imperial Highway, West Coyote Hills, Fullerton, Orange County, CA. Site stratigraphically about $82 \mathrm{~m}$ above base of exposed "San Pedro" Formation and within a few meters of the Coyote Hills contact. Collected by David Stevens, 4/1/ 97.

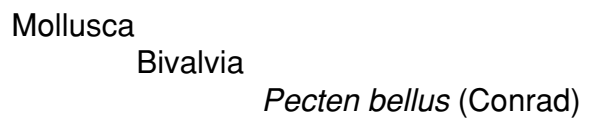


Field No.: RMW/DNS 1139. "Friable white fine sand. San Pedro Formation. Location: old school site in main canyon, elevation 420' [130 m]." Locality located in former oil field about $0.54 \mathrm{~km} \mathrm{~S}$ of Imperial Highway $0.34 \mathrm{~km} E$ of its intersection with Beach Blvd. and $0.62 \mathrm{~km}$ SE of intersection of Beach Blvd and Imperial Highway, West Coyote Hills, Fullerton, Orange County, CA. Site stratigraphically about $65 \mathrm{~m}$ above base of exposed "San Pedro" Formation. Collected by David Stevens, 6/11/97.

Mollusca

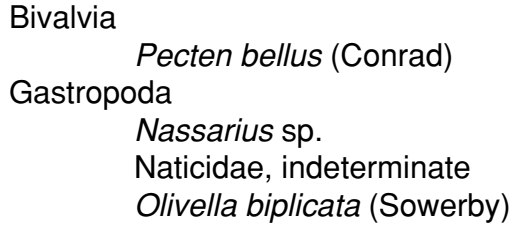

Field No.: RMW/DNS 1146. "Gray pebbly sandstone. San Pedro Formation. Location: buttress by crib wall, elevation 430' [130 m]." Locality located in former oil field about $0.98 \mathrm{~km} \mathrm{~S}$ of Imperial Highway $0.57 \mathrm{~km} \mathrm{E}$ of its intersection with Beach Blvd. and $1.14 \mathrm{~km} \mathrm{SE}$ of intersection of Beach Blvd and Imperial Highway, West Coyote Hills, Fullerton, Orange County, CA. Site stratigraphically about $82 \mathrm{~m}$ above base of exposed "San Pedro" Formation. Collected by David Stevens, 7/1/1997.

Mollusca

Bivalvia

Gastropoda

Pecten bellus (Conrad) Tresus nuttalli (Conrad)

Fusinus sp., cf. F. barbarensis (Trask)

Nassarius sp., cf. N. perpinguis (Hinds)

Naticidae, indeterminate

Olivella biplicata (Sowerby)

Echinodermata

Echinoidea

Dendraster sp.

**Field No.: RMW/DNS 1147 [= RMW/DNS 1146]. "Gray pebbly sandstone. San Pedro Formation. Location: buttress by crib wall, elevation 430' [130 m]." Locality located in former oil field about $0.98 \mathrm{~km} \mathrm{~S}$ of Imperial Highway $0.57 \mathrm{~km}$ E of its intersection with Beach Blvd. and $1.14 \mathrm{~km}$ SE of intersection of Beach Blvd and Imperial Highway, West Coyote Hills, Fullerton, Orange County, CA. Site stratigraphically about $82 \mathrm{~m}$ above base of exposed "San Pedro" Formation. Collected by David Stevens, 7/1/1997. Mollusca

Bivalvia

Macoma? sp.

Pectinidae, indeterminate

Gastropoda

Astyris gausapata (Gould)

Conus californicus Reeve

Nassarius mendicus (Gould)

Nassarius sp., cf. N. perpinguis (Hinds)

Naticidae, indeterminate

Ocenebra sp., cf. O. foveolata (Hinds)

Olivella biplicata (Sowerby)

Echinodermata

Echinodea

Dendraster sp.

Field No.: RMW/DNS 1151. "Hard shelly sand. San Pedro Formation. Location: key cut 1/2 way down main ridge, elevation $365^{\prime}$ [111 m]." Locality located in former oil field about $0.71 \mathrm{~km} \mathrm{~S}$ of Imperial Highway $0.48 \mathrm{~km}$ $E$ of its intersection with Beach Blvd. and $0.85 \mathrm{~km}$ SE of intersection of Beach Blvd and Imperial Highway, West Coyote Hills, Fullerton, Orange County, CA. Site stratigraphically about $77 \mathrm{~m}$ above base of exposed "San Pedro" Formation. Collected by David Stevens, 7/16/97.

Mollusca

Bivalvia

Cardiidae, indeterminate 


Cyathodonta pedroana Dall
Lucinoma annulata (Reeve)
Panope abrupta (Conrad)
Pecten bellus (Conrad)
Tellinid, indeterminate
Gastropoda
Astyris gausapata (Gould)
Conus californicus Reeve
Crepidula princeps Conrad
Nassarius mendicus (Gould)
Naticidae, indeterminate
Olivella biplicata (Sowerby)
Ophiodermella sp.
Turritella cooperi Carpenter
Scaphopoda
Dentalium neohexagonum Pilsbry \& Sharp
Arthropoda

Field No.: RMW/DNS 1175. "Tan siltstone. San Pedro Formation. Location: West end of site, elevation 370' [110 m]." Locality located in former oil field about $1.15 \mathrm{~km} \mathrm{~S}$ of Imperial Highway $0.52 \mathrm{~km} E$ of its intersection with Beach Blvd. and $1.29 \mathrm{~km}$ SSW of intersection of Beach Blvd and Imperial Highway, West Coyote Hills, Fullerton, Orange County, CA. Site stratigraphically about $16 \mathrm{~m}$ above base of exposed "San Pedro" Formation. Collected by David Stevens, 11/20/97.

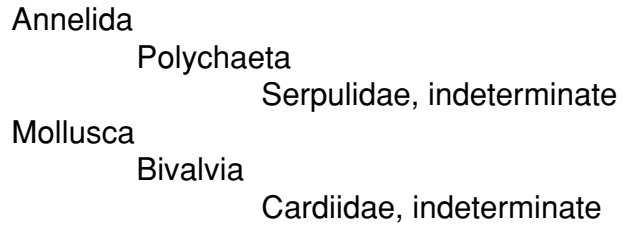

Field No.: RMW/DNS 1176. "Gray to tan siltstone. San Pedro Formation. Location: ridge between Canyons 3 and 4, elevation 335' [102 m]." Locality located in former oil field about $0.61 \mathrm{~km} \mathrm{~S}$ of Imperial Highway 0.14 $\mathrm{km}$ E of its intersection with Beach Blvd. and $0.64 \mathrm{~km}$ SSE of intersection of Beach Blvd and Imperial Highway, West Coyote Hills, Fullerton, Orange County, CA. Site stratigraphically about $37 \mathrm{~m}$ above base of exposed "San Pedro" Formation. Collected by David Stevens, 11/20/97.

Mollusca

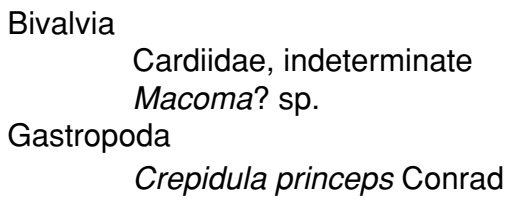

Crepidula princeps Conrad

Field No.: RMW/DNS 1181. "Tan to gray siltstone and mudstone. San Pedro Formation. Location: key at southwest end of Canyon 7, elevation 345' [105 m]." Locality located in former oil field about $0.97 \mathrm{~km}$ S of Imperial Highway $0.55 \mathrm{~km}$ W of its intersection with Beach Blvd. and $1.12 \mathrm{~km} \mathrm{SSW}$ of intersection of Beach Blvd and Imperial Highway, West Coyote Hills, Fullerton, Orange County, CA. Site stratigraphically about 29 m above base of exposed "San Pedro" Formation. Collected by David Stevens, 12/15/97. Middle fauna.

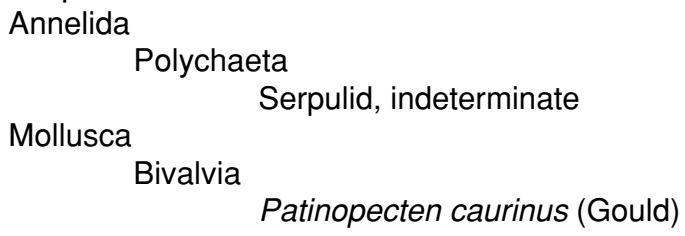

Field No.: RMW/DNS 1205. "Gray to tan mudstone and sand. San Pedro Formation. Location: Canyon 6." Locality located in former oil field about $1.05 \mathrm{~km} \mathrm{~S}$ of Imperial Highway $0.63 \mathrm{~km} \mathrm{~W}$ of its intersection with Beach Blvd. and $1.22 \mathrm{~km}$ SSW of intersection of Beach Blvd and Imperial Highway, West Coyote Hills, Fullerton, Orange County, CA. Site stratigraphically about $4 \mathrm{~m}$ above base of exposed "San Pedro" Forma- 
tion. Collected by David Stevens, 3/12/98. Middle fauna.

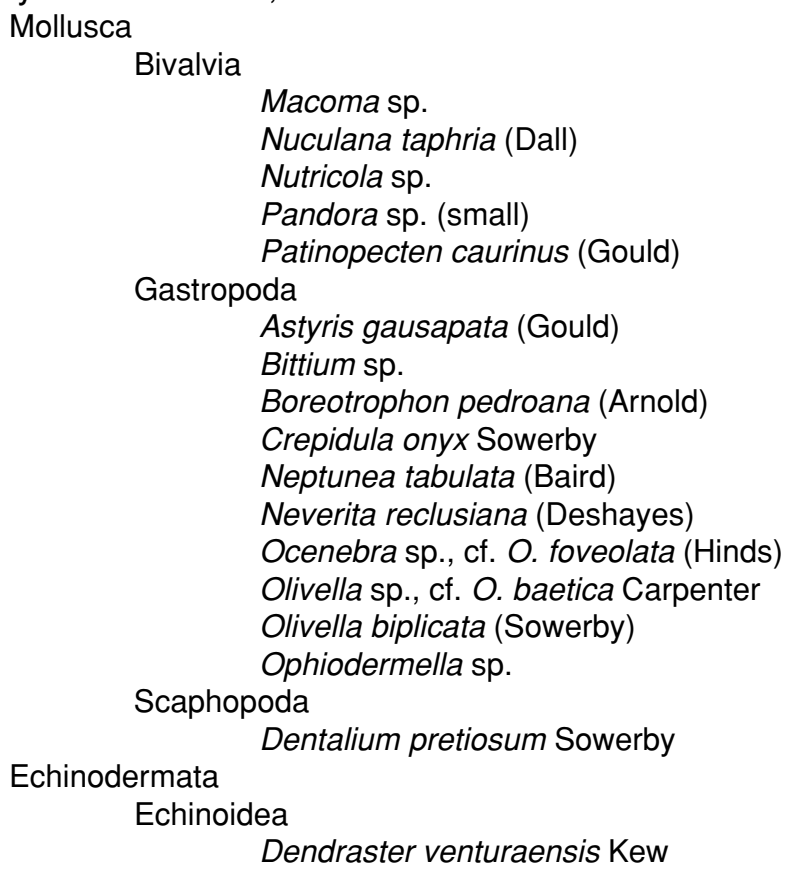

Field No.: RMW/DNS 1206. "Tan siltstone. San Pedro Formation. Location: Canyon 6 slide." Locality located in former oil field about $1.19 \mathrm{~km}$ S of Imperial Highway $0.59 \mathrm{~km}$ E of its intersection with Beach Blvd. and $1.31 \mathrm{~km}$ SSW of intersection of Beach Blvd and Imperial Highway, West Coyote Hills, Fullerton, Orange County, CA. Site stratigraphically about $51 \mathrm{~m}$ above base of exposed "San Pedro" Formation. Collected by David Stevens, 3/16/98. Middle fauna.

Mollusca

Bivalvia

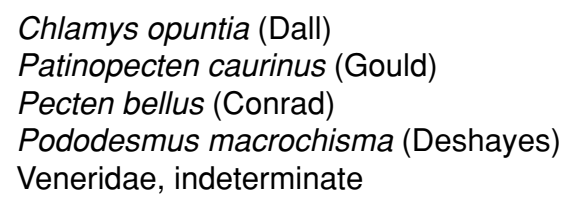

Field No.: RMW/DNS 1207. "Tan mudstone. San Pedro Formation. Location: Canyon 7, elevation 265' [80 m]." Locality located in former oil field about $1.20 \mathrm{~km} \mathrm{~S}$ of Imperial Highway $0.67 \mathrm{~km} \mathrm{E}$ of its intersection with Beach Blvd. and $1.28 \mathrm{~km}$ SSW of intersection of Beach Blvd and Imperial Highway, West Coyote Hills, Fullerton, Orange County, CA. Site stratigraphically about $29 \mathrm{~m}$ above base of exposed "San Pedro" Formation. Collected by David Stevens, 3/16/1998. Middle fauna.

Mollusca

Bivalvia

Patinopecten sp., cf. P. caurinus (Gould)

${ }^{* \star}$ Field No.: RMW/DNS 1213. "Gray siltstone. Sand Pedro Formation. Location: ridge between Canyon 3 and 4, elevation 335' [102 m]." Locality located in former oil field about $0.61 \mathrm{~km} \mathrm{~S}$ of Imperial Highway 0.61 $\mathrm{km} \mathrm{E}$ of its intersection with Beach Blvd. and $1.2 \mathrm{~km}$ SSE of intersection of Beach Blvd and Imperial Highway, West Coyote Hills, Fullerton, Orange County, CA. Site stratigraphically about $37 \mathrm{~m}$ above base of exposed "San Pedro" Formation. Collected by David Stevens, 4/17/97. Middle fauna.

Mollusca Bivalvia

Cardiidae, indeterminate

Chlamys sp.

Clinocardium sp.

Cyclocardia sp., cf. C. occidentalis (Conrad)

Lucinoma annulata (Reeve)

Patinopecten caurinus (Gould) 
Field No.: RMW/DNS 1219. "Fine silt and sand. San Pedro Formation. Location: Pad 135 between Canyon 5 and 6., elevation 380' [120 m]." Locality located in former oil field about $1.07 \mathrm{~km}$ S of Imperial Highway 0.50 $\mathrm{km} \mathrm{E}$ of its intersection with Beach Blvd. and $1.15 \mathrm{~km} \mathrm{SSW}$ of intersection of Beach Blvd and Imperial Highway, West Coyote Hills, Fullerton, Orange County, CA. Site stratigraphically about $51 \mathrm{~m}$ above base of exposed "San Pedro" Formation. Collected by David Stevens, 4/23/98.

Mollusca

Bivalvia

Modiolus rectus (Conrad)

Panope abrupta (Conrad)

Pododesmus macrochisma (Deshayes)

Field No.: RMW/DNS 1222. "Tan sand. San Pedro Formation. Location: toe of ridge between Canyons 2 and 3, elevation 263' [80 m]." Locality located in former oil field about $0.45 \mathrm{~km}$ S of Imperial Highway $0.25 \mathrm{~km}$ $E$ of its intersection with Beach Blvd. and $0.50 \mathrm{~km}$ SSE of intersection of Beach Blvd and Imperial Highway, West Coyote Hills, Fullerton, Orange County, CA. Site stratigraphically about $71 \mathrm{~m}$ above base of exposed "San Pedro" Formation. Collected by David Stevens, 4/29/98.

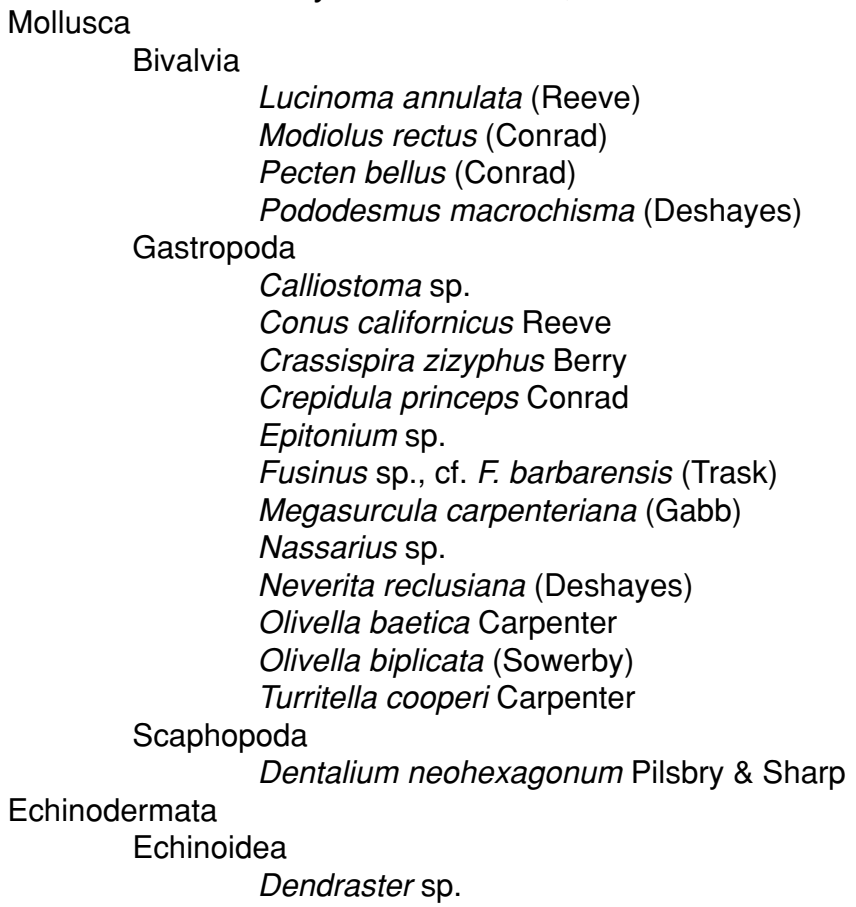

Field No.: RMW/DPO 9. "Dark gray siltstone to mudstone. San Pedro Formation. Location: 100 yards [91 $\mathrm{m}] \mathrm{SW}$ of well 232 , elevation $250^{\prime}$ [76 m]." Locality located in former oil field about $1.05 \mathrm{~km}$ S of Imperial Highway $0.63 \mathrm{~km}$ W of its intersection with Beach Blvd. and $1.22 \mathrm{~km} \mathrm{SSW}$ of intersection of Beach Blvd and Imperial Highway, West Coyote Hills, Fullerton, Orange County, CA. Site stratigraphically about $27 \mathrm{~m}$ above base of exposed "San Pedro" Formation. Collected by Dan Orris, 6/24/98.

Mollusca

Gastropoda

Naticidae, indeterminate

Field No.: RMW/EAB 002. "Black silt. Coyote Hills Formation. Location: near slide, Canyon 3, elevation 500 ' [150 m]." Locality located in former oil field about $1.07 \mathrm{~km} \mathrm{~S}$ of Imperial Highway $0.38 \mathrm{~km}$ E of its intersection with Beach Blvd. and $1.12 \mathrm{~km}$ SSE of intersection of Beach Blvd and Imperial Highway, West Coyote Hills, Fullerton, Orange County, CA. Site stratigraphically from 98 to $107 \mathrm{~m}$ above base of exposed "San Pedro" Formation in Coyote Hills Formation. Collected by Edwin Bragado, 6/4/97. 
Mollusca
\[ \begin{array}{l}\text { Bivalvia } \\ \text { Macoma sp. } \\ \end{array} \]

Field No.: RMW/EAB 003. "Coarse sand. San Pedro Formation. Location: Well MC96." Locality located in former oil field about $1.03 \mathrm{~km} \mathrm{~S}$ of Imperial Highway $0.60 \mathrm{~km} \mathrm{E}$ of its intersection with Beach Blvd. and 1.16 km SE of intersection of Beach Blvd and Imperial Highway, West Coyote Hills, Fullerton, Orange County, CA. Site stratigraphically about $78 \mathrm{~m}$ above base of exposed "San Pedro" Formation. Collected by Edwin Bragado, 6/4/97.

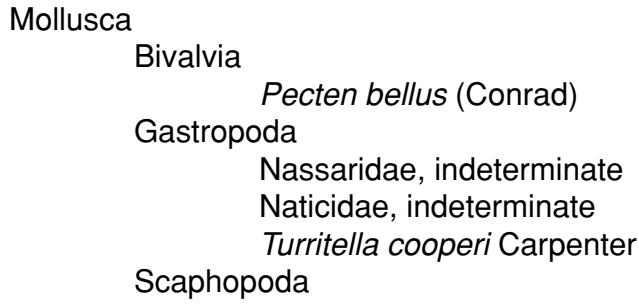

Dentalium neohexagonum Pilsbry \& Sowerby

Field No.: RMW/EAB 023. "Coarse sand. San Pedro Formation. Location: west of Well MC322." Locality located in former oil field about $1.08 \mathrm{~km} \mathrm{~S}$ of Imperial Highway $0.40 \mathrm{~km} E$ of its intersection with Beach Blvd. and $1.14 \mathrm{~km}$ SSE of intersection of Beach Blvd and Imperial Highway, West Coyote Hills, Fullerton, Orange County, CA. Site stratigraphically about $50 \mathrm{~m}$ above base of exposed "San Pedro" Formation. Collected by Edwin Bragado, 6/23/97.

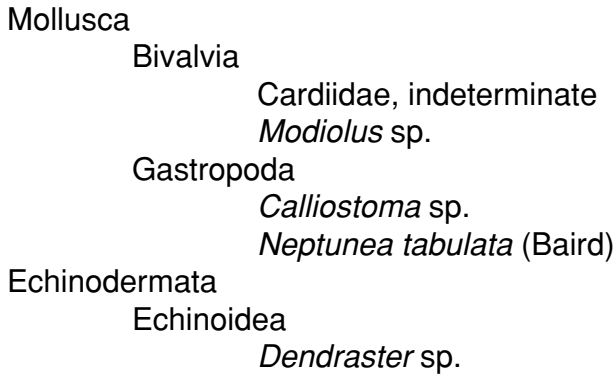

Dendraster sp.

Field No.: RMW/EAB 024. "7976 m 1202; elevation 382' [116 m]. Sand. San Pedro Formation." Locality located in former oil field about $0.78 \mathrm{~km} \mathrm{~S}$ of Imperial Highway $0.74 \mathrm{~km}$ E of its intersection with Beach Blvd. and $1.07 \mathrm{~km}$ SE of intersection of Beach Blvd and Imperial Highway, West Coyote Hills, Fullerton, Orange County, CA. Site stratigraphically about $66 \mathrm{~m}$ above base of exposed "San Pedro" Formation. Collected by Edwin Bragado, 6/24/97.

Mollusca

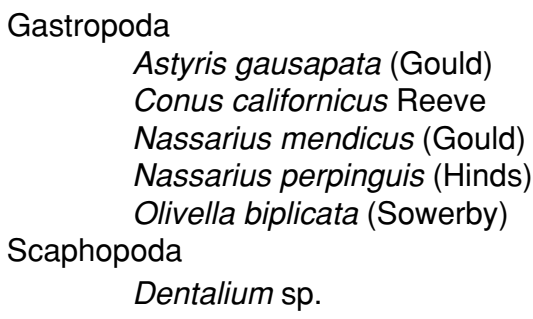

Dentalium sp.

Field No.: RMW/EAB 045 (= RMW EAB 045.5). "Near Idaho St. Sand and sandstone. San Pedro Formation." Locality located in former oil field about $0.73 \mathrm{~km} \mathrm{~S}$ of Imperial Highway $0.50 \mathrm{~km} E$ of its intersection with Beach Blvd. and $0.88 \mathrm{~km}$ SE of intersection of Beach Blvd and Imperial Highway, West Coyote Hills, Fullerton, Orange County, CA. Site stratigraphically about $78 \mathrm{~m}$ above base of exposed "San Pedro" Formation. Collected by Edwin Bragado, 7/18/97. Mollusca

Bivalvia 


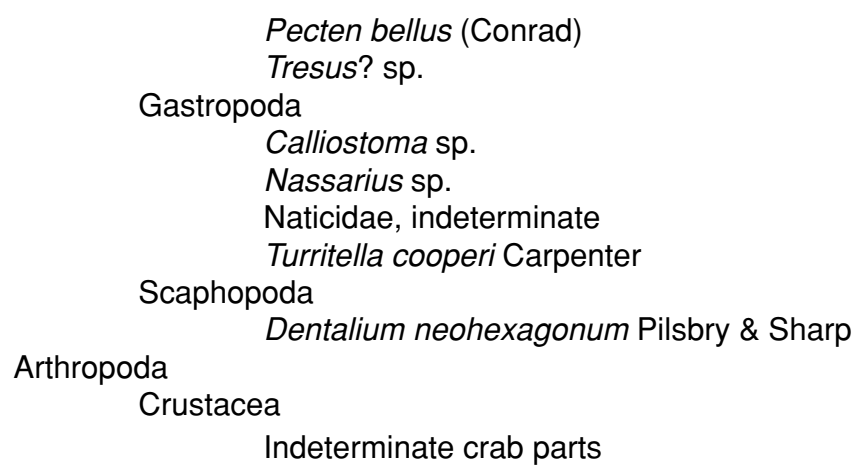

Field No.: RMW/EAB 051. "Concretions. San Pedro Formation. Location: near Well MC96." Locality located in former oil field about $0.96 \mathrm{~km}$ S of Imperial Highway $0.59 \mathrm{~km}$ E of its intersection with Beach Blvd. and $1.12 \mathrm{~km}$ SE of intersection of Beach Blvd and Imperial Highway, West Coyote Hills, Fullerton, Orange County, CA. Site stratigraphically about $82 \mathrm{~m}$ above base of exposed "San Pedro" Formation. Collected by Edwin Bragado, 7/23/97.

Mollusca

Gastropoda

Crepidula princeps Conrad

Field No.: RMW/EAB 052. "Sandstone and sand. San Pedro Formation. Location: far right side of slide." Locality located in former oil field about $1.02 \mathrm{~km}$ S of Imperial Highway $0.50 \mathrm{~km} \mathrm{E}$ of its intersection with Beach Blvd. and $1.13 \mathrm{~km}$ SE of intersection of Beach Blvd and Imperial Highway, West Coyote Hills, Fullerton, Orange County, CA. Site stratigraphically about $82 \mathrm{~m}$ above base of exposed "San Pedro" Formation. Collected by Edwin Bragado, 7/23/97.

Mollusca

Gastropoda

Astyris gausapata (Gould)

Conus californicus Reeve

Nassarius mendicus (Gould)

Nassarius sp.

Naticidae, indeterminate

Ocenebra sp., cf. O. foveolata (Hinds)

Olivella biplicata (Sowerby)

Scaphopoda

Turbonilla sp.

Echinodermata

Dentalium sp.

Echinoidea

Dendraster sp.

Field No.: RMW/EAB 053. "Sand. San Pedro Formation. Location: near golf course hole 16." Locality located in former oil field about $1.04 \mathrm{~km} \mathrm{~S}$ of Imperial Highway $0.6 \mathrm{~km} \mathrm{E}$ of its intersection with Beach Blvd. and $1.17 \mathrm{~km}$ SE of intersection of Beach Blvd and Imperial Highway, West Coyote Hills, Fullerton, Orange County, CA. Site stratigraphically about $69 \mathrm{~m}$ above base of exposed "San Pedro" Formation. Collected by Edwin Bragado, 7/23/97.

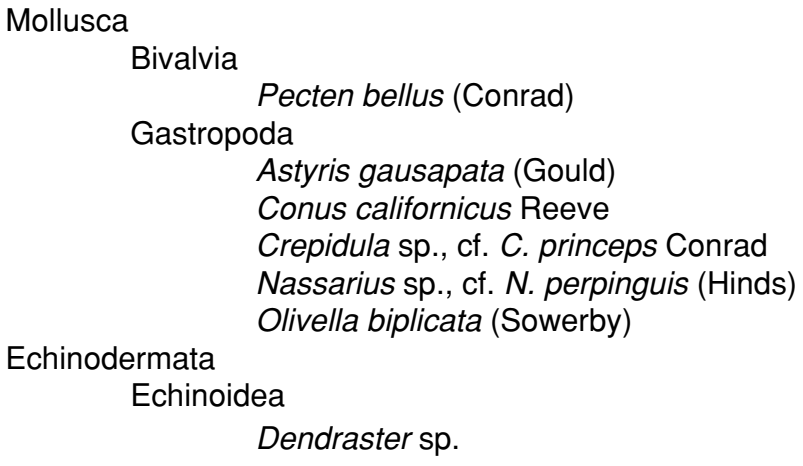

Dendraster sp. 
Field No.: RMW/EAB 081. "Sandy bed with conglomerate and concretions. San Pedro Formation. Location: near Well MC96." Locality located in former oil field about $0.96 \mathrm{~km} \mathrm{~S}$ of Imperial Highway $0.59 \mathrm{~km} E$ of its intersection with Beach Blvd. and $1.12 \mathrm{~km}$ SE of intersection of Beach Blvd and Imperial Highway, West Coyote Hills, Fullerton, Orange County, CA. Site stratigraphically about $82 \mathrm{~m}$ above base of exposed "San Pedro" Formation. Collected by Edwin Bragado, 8/13/97.

Mollusca

Bivalvia

Gastropoda

Tresus sp.

Kelletia sp.

Field No.: RMW/EAB 090. "Sand. San Pedro Formation. Location: near Well MC239." Locality located in former oil field about $0.92 \mathrm{~km} \mathrm{~S}$ of Imperial Highway $0.63 \mathrm{~km} E$ of its intersection with Beach Blvd. and 1.13 km SE of intersection of Beach Blvd and Imperial Highway, West Coyote Hills, Fullerton, Orange County, CA. Site stratigraphically about $82 \mathrm{~m}$ above base of exposed "San Pedro" Formation. Collected by Edwin Bragado, 8/26/97.

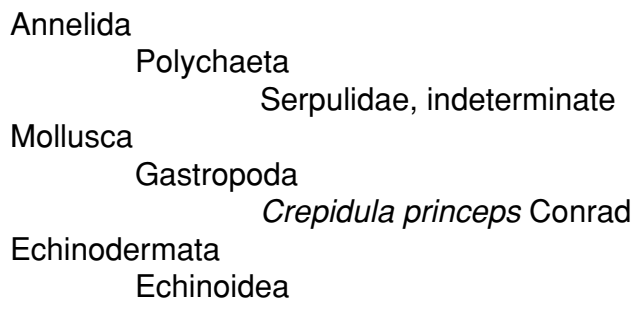

Dendraster sp.

Field No.: RMW/EAB 121. "Silt with mud. San Pedro Formation. Location: front of Chevron facility." Locality located in former oil field about $0.50 \mathrm{~km} \mathrm{~S}$ of Imperial Highway $0.29 \mathrm{~km}$ E of its intersection with Beach Blvd. and $0.57 \mathrm{~km}$ SE of intersection of Beach Blvd and Imperial Highway, West Coyote Hills, Fullerton, Orange County, CA. Site stratigraphically about $69 \mathrm{~m}$ above base of exposed "San Pedro" Formation. Collected by Edwin Bragado, 12/29/97. Middle fauna.

Mollusca

Bivalvia

Cardiidae, indeterminate

Compsomyax? sp.

Modiolus sp.

Panope? sp.

Patinopecten caurinus (Gould)

Gastropoda

Tresus? sp.

Crepidula princeps Conrad

Tegula pulligo (Gmelin)

Field No.: RMW/JRS 693. "Medium to fine silt and clay. Coyote Hills Formation. Location: cut below house on Skyline Dr., elevation 295'." Locality located in former oil field about $2.04 \mathrm{~km} \mathrm{SSW}$ of intersection of State College Blvd. and Bastanchury Rd. and $0.69 \mathrm{~km} \mathrm{SW}$ of intersection of Bastanchury Rd. and Brea Blvd., East Coyote Hills, Fullerton, Orange County, CA. Site stratigraphically about $13 \mathrm{~m}$ above base of exposed "San Pedro" Formation. Collected by Juanita Shinn. Restricted fauna (?) Mollusca Bivalvia Macoma sp.

Field No.: RMW/JRS 707. "Medium to coarse sand. San Pedro Formation. Location: cut below native plant park." Locality located in former oil field about $0.27 \mathrm{~km} \mathrm{SW}$ of intersection of State College Blvd. and Bastanchury Rd., East Coyote Hills, Fullerton, Orange County, CA. Site stratigraphically about $6 \mathrm{~m}$ above base of exposed "San Pedro" Formation. Collected by Juanita Shinn, 5/2/94.

Mollusca

Bivalvia

Dendostrea? vespertina (Conrad) 
Field No.: RMW/JRS 740. "Fine grained silt with sand. Coyote Hills Formation. Location: cut below restaurant off State College Blvd., elevation 398'." Locality located in former oil field about $0.25 \mathrm{~km} \mathrm{SW}$ of intersection of State College Blvd. and Bastanchury Rd., East Coyote Hills, Fullerton, Orange County, CA. Site stratigraphically about 13 m above base of exposed "San Pedro" Formation. Collected by Juanita Shinn, 6/9/ 94. Restricted fauna.

Mollusca

Bivalvia

Macoma sp.

Tagelus sp., cf. T. subteres (Conrad)

Field No.: RMW/JRS 788. "Coyote Hills Formation. Location: large hill cut next to native habitat area, elevation 350'." Locality located in former oil field about $0.37 \mathrm{~km} \mathrm{SW}$ of intersection of State College Blvd. and Bastanchury Rd., East Coyote Hills, Fullerton, Orange County, CA. Site stratigraphically about $13 \mathrm{~m}$ above base of exposed "San Pedro" Formation. Collected by Juanita Shinn, 8/25/94. Restricted fauna.

Mollusca

Bivalvia

Macoma sp.

Field No.: RMW/JRS 819. "Fine grain blocky siltstone. Coyote Hills Formation. Location: old trailer hill next to Bastanchury." Locality located in former oil field about $0.87 \mathrm{~km} \mathrm{SW}$ of intersection of State College Blvd. and Bastanchury Rd. and $0.11 \mathrm{~km}$ WSW of Hill 496 ESE of intersection of Acacia Dr. and Ladera Vista Dr., East Coyote Hills, Fullerton, Orange County, CA. Site stratigraphically about $13 \mathrm{~m}$ above base of exposed "San Pedro" Formation. Collected by Juanita Shinn, 11/7/94. Restricted fauna.

Mollusca

Bivalvia

Tagelus sp., cf. T. subteres (Conrad)

Tellinidae, indeterminate

Field No.: RMW/JRS 855. Locality located in former oil field about $1.25 \mathrm{~km} \mathrm{SW}$ of intersection of State College Blvd. and Bastanchury Rd. and about 0.69 km E of BM 331 on Brea Blvd., East Coyote Hills, Fullerton, Orange County, CA. Site stratigraphically about $6 \mathrm{~m}$ above base of exposed "San Pedro" Formation. Collected by Juanita Shinn. Lower fauna.

Mollusca

Bivalvia

Cyathodonta pedroana Dall

Cyclocardia sp.

Dendostrea? sp., aff. $D$ ? vespertina (Conrad)

Leporimetis obesa (Deshayes)

Nuculana taphria (Dall)

Panope abrupta (Conrad)

Pecten bellus (Conrad)

Spisula? sp.

Gastropoda

Tresus? sp.

Alia carinata (Hinds)

Astrea sp., cf. A. undosa (Wood)

Bulla gouldiana Pilsbry

Calicantharus sp.

Calliostoma gemmulatum Carpenter

Calliostoma sp., cf. C. ligatum (Gould)

Calliostoma sp.

Cancellaria arnoldi (Dall)

Cancellaria tritonidae (Gabb)

Cancellaria sp.

Conus californicus Reeve

Crassispira semiinflata (Grant and Gale)

Crassispira zizyphus Berry

Crepidula sp., cf. C. onyx Sowerby

Crepidula sp., cf. C. princeps (Conrad) 


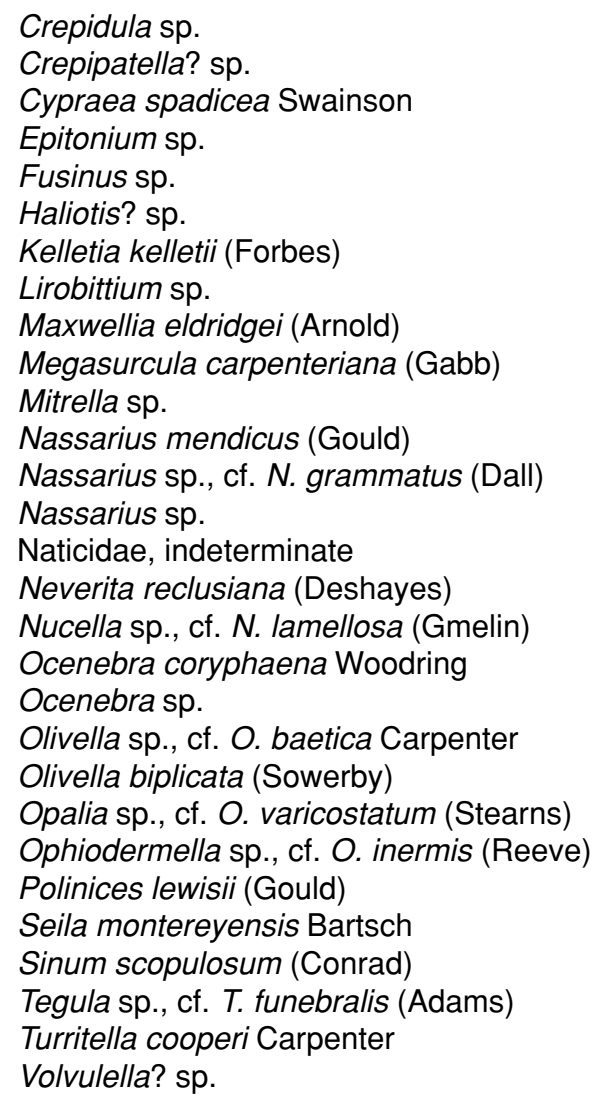

Field No.: RMW/JRS 1320. "Gray to green fine silt. Coyote Hills Formation. Location: 40' key cut." Locality located in former oil field about $0.94 \mathrm{~km}$ S of Imperial Highway $0.58 \mathrm{~km}$ E of its intersection with Beach Blvd. and $1.12 \mathrm{~km}$ SE of intersection of Beach Blvd and Imperial Highway, West Coyote Hills, Fullerton, Orange County, CA. Site stratigraphically from 98 to $107 \mathrm{~m}$ above base of exposed "San Pedro" Formation in Coyote Hills Formation. Collected by Juanita Shinn, 4/21/97. Restricted fauna.

Mollusca

Bivalvia

Macoma sp.

Tagelus sp.

Indeterminate bivalves

Field No.: RMW/JRS 1325. "Green clay. Coyote Hills Formation. Location: cut opposite park next to Idaho Street, elevation 411' [125 m]." Locality located in former oil field about $0.95 \mathrm{~km} \mathrm{~S}$ of Imperial Highway 0.59 $\mathrm{km} E$ of its intersection with Beach Blvd. and $1.12 \mathrm{~km} \mathrm{SE}$ of intersection of Beach Blvd and Imperial Highway, West Coyote Hills, Fullerton, Orange County, CA. Site stratigraphically from 98 to $107 \mathrm{~m}$ above base of exposed "San Pedro" Formation in the Coyote Hills Formation. Collected by Juanita Shinn, 4/23/97. Restricted fauna.

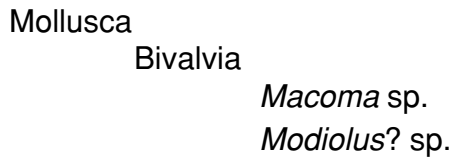

Field No.: RMW/JRS 1339. "Fine sand. San Pedro Formation. Location: cut above 40' [12 m] buttress, elevation 460' [140 m]." Locality located in former oil field about $0.97 \mathrm{~km} \mathrm{~S}$ of Imperial Highway $0.58 \mathrm{~km} E$ of its intersection with Beach Blvd. and $1.14 \mathrm{~km}$ SE of intersection of Beach Blvd and Imperial Highway, West Coyote Hills, Fullerton, Orange County, CA. Site stratigraphically about $66 \mathrm{~m}$ above base of exposed "San Pedro" Formation. Collected by Juanita Shinn, 5/7/97. Upper fauna.

Mollusca

Bivalvia

Argopecten? sp. 


\author{
Lucinisca nuttalli (Conrad) \\ Pecten bellus Conrad \\ Gastropoda \\ Naticidae indeterminate \\ Scaphopoda \\ Dentalium neohexagonum Pilsbry \& Sharp
}

Field No.: RMW/JRS 1378. "Medium to coarse sand and conglomerate. San Pedro Formation. Location: cut below slide, elevation 140' [40 m]." Locality located in former oil field about $0.98 \mathrm{~km}$ S of Imperial Highway $0.57 \mathrm{~km}$ E of its intersection with Beach Blvd. and $1.14 \mathrm{~km}$ SE of intersection of Beach Blvd and Imperial Highway, West Coyote Hills, Fullerton, Orange County, CA. Site stratigraphically about $82 \mathrm{~m}$ above base of exposed "San Pedro" Formation. Collected by Juanita Shinn, 6/20/97.

Mollusca

Bivalvia

Gastropoda

Tellinidae, indeterminate

Nassarius sp.

Echinodermata

Olivella biplicata (Sowerby)

Echinoidea

Dendraster sp.

Field No.: RMW/JRS 1379. "Medium to coarse sand. San Pedro Formation. Location: cut below slide, elevation 140' [43 m]." Locality located in former oil field about $0.99 \mathrm{~km} \mathrm{~S}$ of Imperial Highway $0.57 \mathrm{~km}$ E of its intersection with Beach Blvd. and $1.15 \mathrm{~km}$ SE of intersection of Beach Blvd and Imperial Highway, West Coyote Hills, Fullerton, Orange County, CA. Site stratigraphically about $82 \mathrm{~m}$ above base of exposed "San Pedro" Formation. Collected by Juanita Shinn, 6/30/97.

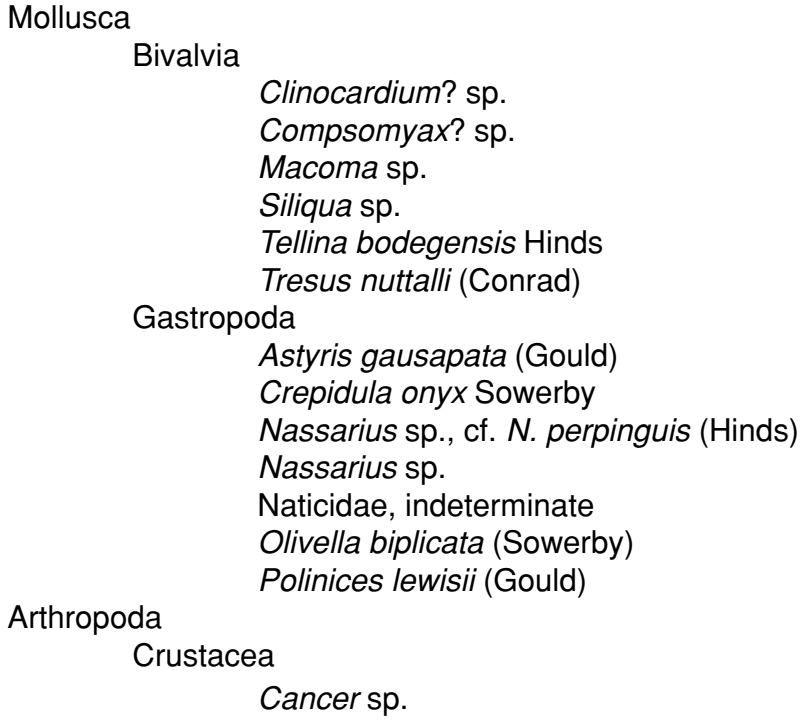

Cancersp.

Field No.: RMW/JRS 1389. "Fine sand. San Pedro Formation. Location: Well 371, elevation 290 ' [88 m]." Locality located in former oil field about $0.62 \mathrm{~km}$ S of Imperial Highway $0.45 \mathrm{~km}$ E of its intersection with Beach Blvd. and $0.77 \mathrm{~km}$ SE of intersection of Beach Blvd and Imperial Highway, West Coyote Hills, Fullerton, Orange County, CA. Site stratigraphically about $82 \mathrm{~m}$ above base of exposed "San Pedro" Formation. Collected by Juanita Shinn, 7/14/97.

Mollusca

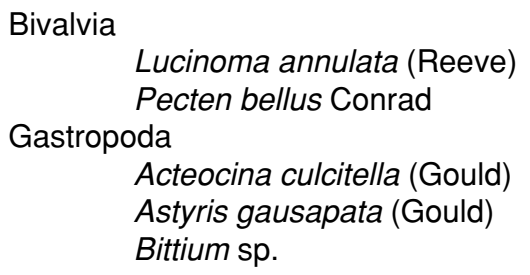




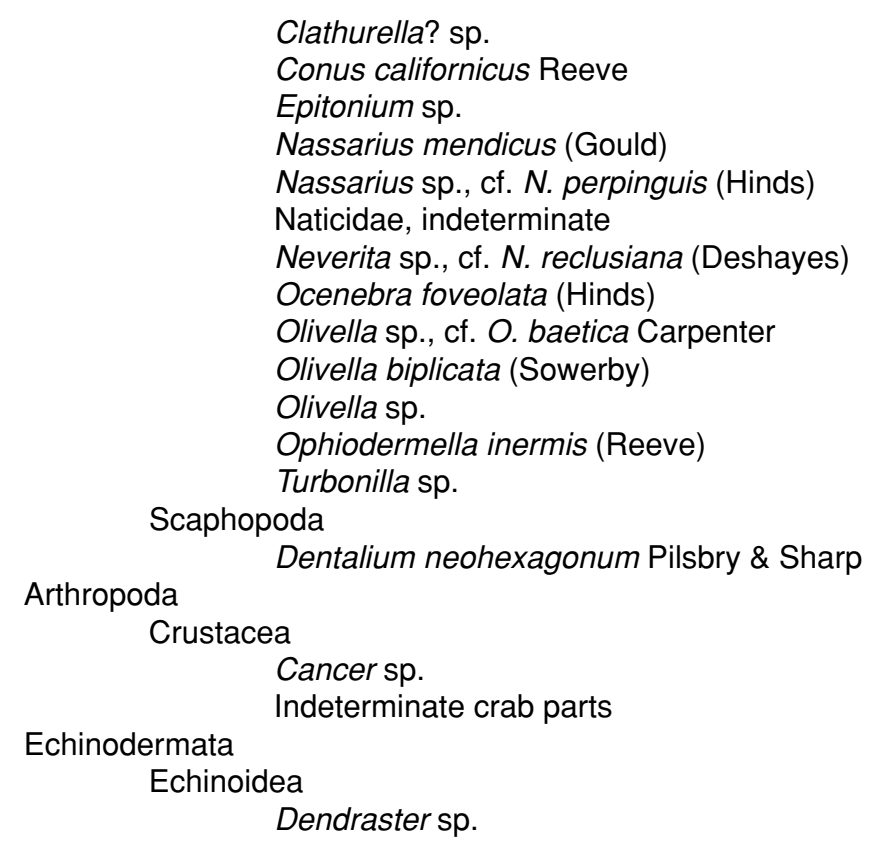

Field No.: RMW/JRS 1399. "Canyon 1; elevation 542' [165 m]. Fine grained sand with concretions. San Pedro Formation." Locality located in former oil field about $1.04 \mathrm{~km} \mathrm{~S}$ of Imperial Highway $0.68 \mathrm{~km} E$ of its intersection with Beach Blvd. and $1.23 \mathrm{~km}$ SE of intersection of Beach Blvd and Imperial Highway, West Coyote Hills, Fullerton, Orange County, CA. Site stratigraphically about $78 \mathrm{~m}$ above base of exposed "San Pedro" Formation. Collected by Juanita Shinn, 7/31/97.

Mollusca

Bivalvia

Teredidae, indet

Field No.: RMW/JRS 1400. "Fine sand. San Pedro Formation. Location: road cut below concrete wall, elevation 520' [160 m]." Locality located in former oil field about $1.16 \mathrm{~km} \mathrm{~S}$ of Imperial Highway $0.69 \mathrm{~km} E$ of its intersection with Beach Blvd. and $1.35 \mathrm{~km}$ SE of intersection of Beach Blvd and Imperial Highway, West Coyote Hills, Fullerton, Orange County, CA. Site stratigraphically about $78 \mathrm{~m}$ above base of exposed "San Pedro" Formation. Collected by Juanita Shinn, 7/31/97.

Mollusca

Bivalvia

Cardiidae, indeterminate

Field No.: RMW/JRS 1425. "Fine gray sand with concretions. San Pedro Formation. Location: Well 214, elevation 369' [112 m]." Locality located in former oil field about $0.84 \mathrm{~km} \mathrm{~S}$ of Imperial Highway $0.43 \mathrm{~km} E$ of its intersection with Beach Blvd. and $0.94 \mathrm{~km}$ SE of intersection of Beach Blvd and Imperial Highway, West Coyote Hills, Fullerton, Orange County, CA. Site stratigraphically about $82 \mathrm{~m}$ above base of exposed "San Pedro" Formation. Collected by Juanita Shinn, 9/3/97.

Mollusca

Bivalvia

Cyathodonta pedroana Dall

Gari? sp.

Lucinoma annulata (Reeve)

Modiolus sp.

Nuculana sp.

Panope abrupta (Conrad)

Solen sp.

Gastropoda

Calliostomasp.

Conus californicus Reeve

Megasurcula carpenteriana (Gabb)

Neverita reclusiana (Deshayes) 


\section{Scaphopoda}

Turritella cooperi Carpenter

Dentalium neohexagonum Pilsbry \& Sharp

Field No.: RMW/JRS 1429. "Fine beige silt. San Pedro Formation. Location: Canyon 3, elevation 310 ' [94 m]." Locality located in former oil field about $0.51 \mathrm{~km} \mathrm{~S}$ of Imperial Highway $0.37 \mathrm{~km}$ E of its intersection with Beach Blvd. and $0.61 \mathrm{~km}$ SE of intersection of Beach Blvd and Imperial Highway, West Coyote Hills, Fullerton, Orange County, CA. Site stratigraphically about $69 \mathrm{~m}$ above base of exposed "San Pedro" Formation. Collected by Juanita Shinn, 9/8/97.

Mollusca

Bivalvia

Gastropoda

Nuculana taphria (Dall)

Pecten bellus Conrad

Conus californicus Reeve

Crassispira zizyphus Berry

Crepidula princeps Conrad

Nassarius mendicus (Gould)

Nassarius sp., cf. N. perpinguis (Hinds)

Scaphopoda

Neverita sp., cf. N. reclusiana (Deshayes)

Arthropoda

Dentalium neohexagonum Pilsbry \& Sharp

Crustacea

Indeterminate crab parts

Field No.: RMW/JRS 1430. "Fine white sand with concretions. San Pedro Formation. Location: Canyon 3, elevation 303' [92 m]." Locality located in former oil field about $0.64 \mathrm{~km} \mathrm{~S}$ of Imperial Highway $0.28 \mathrm{~km}$ E of its intersection with Beach Blvd. and $0.69 \mathrm{~km}$ SSE of intersection of Beach Blvd and Imperial Highway, West Coyote Hills, Fullerton, Orange County, CA. Site stratigraphically about $69 \mathrm{~m}$ above base of exposed "San Pedro" Formation. Collected by Juanita Shinn, 9/8/97.

Mollusca

Bivalvia

Cardiidae, indeterminate

Gastropoda

Cyathodonta pedroana Dall

Olivella biplicata (Sowerby)

Field No.: RMW/JRS 1434. "Canyon 3; elevation 400' [120 m]. Coarse grain concrete sandstone. San Pedro Formation." Locality located in former oil field about $0.55 \mathrm{~km} \mathrm{~S}$ of Imperial Highway $0.28 \mathrm{~km} E$ of its intersection with Beach Blvd. and $0.62 \mathrm{~km}$ SE of intersection of Beach Blvd and Imperial Highway, West Coyote Hills, Fullerton, Orange County, CA. Site stratigraphically about $69 \mathrm{~m}$ above base of exposed "San Pedro" Formation. Collected by Junita Shinn, 9/16/97.

Echinodermata Echinoidea

\section{Dendraster venturensis Kew}

Field No.: RMW/JRS 1439. "Fine grain sand becoming concreted. San Pedro Formation. Location: Cut above 40' buttress, elevation 460' [140 m]." Locality located in former oil field about $0.53 \mathrm{~km} S$ of Imperial Highway $0.23 \mathrm{~km}$ E of its intersection with Beach Blvd. and $0.58 \mathrm{~km}$ SE of intersection of Beach Blvd and Imperial Highway, West Coyote Hills, Fullerton, Orange County, CA. Site stratigraphically about $66 \mathrm{~m}$ above base of exposed "San Pedro" Formation. Collected by Juanita Shinn, 5/7/97.

Mollusca

Bivalvia

Panope abrupta (Conrad)

Pecten bellus Conrad

Gastropoda

Calliostoma sp.

Crassispira zizyphus Berry

Nassarius mendicus (Gould) 


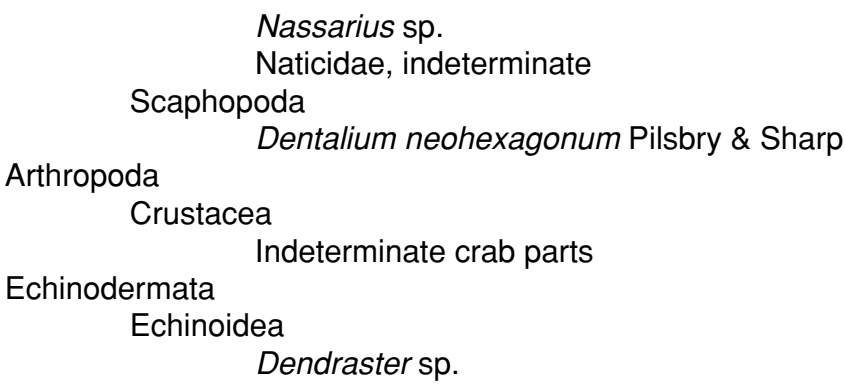

Dendraster sp.

Field No.: RMW/JRS 1447. "Silt below Coyote Hills contact. San Pedro Formation. Location: Northern boundary, canyon 3, elevation about 300'." Locality located in former oil field about $0.73 \mathrm{~km} \mathrm{~S} \mathrm{of} \mathrm{Imperial}$ Highway $0.43 \mathrm{~km} E$ of its intersection with Beach Blvd. and $0.85 \mathrm{~km}$ SE of intersection of Beach Blvd and Imperial Highway, West Coyote Hills, Fullerton, Orange County, CA. Site stratigraphically about $82 \mathrm{~m}$ above base of exposed "San Pedro" Formation. Collected by Juanita Shinn.

Mollusca

Bivalvia

Cardiidae, indeterminate

Lucinoma annulata (Reeve)

Macoma sp.

Gastropoda

Pecten bellus Conrad

Astyris gausapata (Gould)

Amphissa sp., cf. A. reticulata Dall

Bittium sp.

Cancellaria arnoldi (Dall)

Cancellaria sp., cf. C. tritonidae (Gabb)

Conus californicus Reeve

Crassispira zizyphus Berry

Crepidula princeps Conrad

Epitonium sp.

Fusinus? sp.

Megasurcula carpenteriana (Gabb)

Nassarius mendicus (Gould)

Naticidae, indeterminate

Ocenebra foveolata (Hinds)

Turbonilla sp.

Turridae, indeterminate

Scaphopoda

Turritella cooperi Carpenter

Dentalium neohexagonum Pilsbry \& Sharp

Dentalium sp.

Arthropoda

Crustacea

Indeterminate crab parts

Echinodermata

Echinoidea

Indeterminate spines

Field No.: RMW/JRS $1448(\approx$ RMW/JRS 1447). "Silt below Coyote Hills contact. San Pedro Formation. Location: Northern boundary, canyon 3, elevation about 300'." Locality located in former oil field about 0.73 $\mathrm{km}$ S of Imperial Highway $0.43 \mathrm{~km} \mathrm{E}$ of its intersection with Beach Blvd. and $0.85 \mathrm{~km}$ SE of intersection of Beach Blvd and Imperial Highway, West Coyote Hills, Fullerton, Orange County, CA. Site stratigraphically about $82 \mathrm{~m}$ above base of exposed "San Pedro" Formation. Collected by Juanita Shinn.

Mollusca

Bivalvia

Gastropoda

Lucinoma annulata (Reeve)

Conus californicus Reeve

Nassarius mendicus (Gould) 


\author{
Olivella biplicata (Sowerby) \\ Scaphopoda \\ Dentalium sp.
}

Field No.: RMW/MLP 60. "Medium to coarse reddish sand. San Pedro Formation. Location: central cut between fill and cut borrow." Locality located in former oil field about $0.86 \mathrm{~km}$ S of Imperial Highway $0.73 \mathrm{~km}$ $E$ of its intersection with Beach Blvd. and $1.13 \mathrm{~km}$ SE of intersection of Beach Blvd and Imperial Highway, West Coyote Hills, Fullerton, Orange County, CA. Site stratigraphically about $37 \mathrm{~m}$ above base of exposed "San Pedro" Formation. Collected by Matthew Phillips, 3/14/97.

Mollusca

Bivalvia

Ostrea? sp.

Pecten bellus Conrad

Gastropoda

Crepidula? sp.

Field No.: RMW/MLP 64. "Conglomerate with fine to medium sand, sandstone and siltstone. San Pedro Formation. Location: central cut." Locality located in former oil field about $0.88 \mathrm{~km}$ S of Imperial Highway $0.73 \mathrm{~km}$ E of its intersection with Beach Blvd. and $1.14 \mathrm{~km}$ SE of intersection of Beach Blvd and Imperial Highway, West Coyote Hills, Fullerton, Orange County, CA. Site stratigraphically about $37 \mathrm{~m}$ above base of exposed "San Pedro" Formation. Collected by Matthew Phillips, 3/21/97.

Mollusca

Bivalvia

Cyathodonta pedroana Dall

Ostrea? sp.

Pecten bellus Conrad

Field No.: RMW/MLP 69. "Medium to find sand. San Pedro Formation. Location: lower cut on edge of fill below buttress." Locality located in former oil field about $0.80 \mathrm{~km} \mathrm{~S}$ of Imperial Highway $0.73 \mathrm{~km} \mathrm{E} \mathrm{of} \mathrm{its}$ intersection with Beach Blvd. and $1.08 \mathrm{~km}$ SE of intersection of Beach Blvd and Imperial Highway, West Coyote Hills, Fullerton, Orange County, CA. Site stratigraphically about $66 \mathrm{~m}$ above base of exposed "San Pedro" Formation. Collected by Matthew Phillips, 4/24/97.

Mollusca

Bivalvia

Cardiidae, indeterminate

Field No.: RMW/MLP 83. "Sand and silt. San Pedro Formation. Location: side of slope by Canyon 2." Locality located in former oil field about $0.67 \mathrm{~km}$ S of Imperial Highway $0.47 \mathrm{~km}$ E of its intersection with Beach Blvd. and $0.82 \mathrm{~km}$ SE of intersection of Beach Blvd and Imperial Highway, West Coyote Hills, Fullerton, Orange County, CA. Site stratigraphically about $66 \mathrm{~m}$ above base of exposed "San Pedro" Formation. Collected by Matthew Phillips, 7/17/97.

Mollusca

Bivalvia

Lucinoma annulata (Reeve)

Pecten bellus Conrad

Tresus sp.

Gastropoda

Bittium? sp.

Cancellaria arnoldi Dall

Epitonium sp.

Nassarius sp.

Olivella sp., cf. O. baetica Carpenter

Scaphopoda

Turritella cooperi Carpenter

Dentalium neohexagonum Pilsbry \& Sharp

Arthropoda

Crustacea

Indeterminate crab parts 
Field No.: RMW/MLP 84. "Fine sand and conglomerate. San Pedro Formation. Location: top of central ridge." Locality located in former oil field about $0.85 \mathrm{~km} \mathrm{~S}$ of Imperial Highway $0.45 \mathrm{~km} E$ of its intersection with Beach Blvd. and $0.98 \mathrm{~km}$ SE of intersection of Beach Blvd and Imperial Highway, West Coyote Hills, Fullerton, Orange County, CA. Site stratigraphically about $66 \mathrm{~m}$ above base of exposed "San Pedro" Formation. Collected by Matthew Phillips, 6/18/97.

Echinodermata

Echinoidea

Dendraster sp.

Field No.: RMW/MLP 87. "Black petroleum sand. San Pedro Formation. Location: Top below black shale layer." Locality located in former oil field about $1.12 \mathrm{~km} \mathrm{~S}$ of Imperial Highway $0.39 \mathrm{~km} \mathrm{E}$ of its intersection with Beach Blvd. and $1.17 \mathrm{~km}$ SSE of intersection of Beach Blvd and Imperial Highway, West Coyote Hills, Fullerton, Orange County, CA. Site stratigraphically about $50 \mathrm{~m}$ above base of exposed "San Pedro" Formation. Collected by Matthew Phillips, 6/26/97.

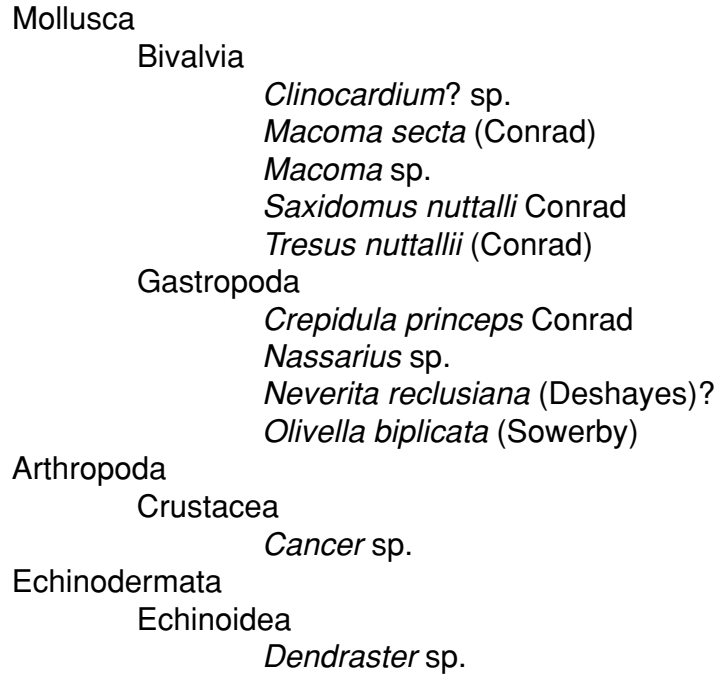

Field No.: RMW/MLP 98. "Concretion layer in medium to fine grained, brownish sand. San Pedro Formation. Location: slot cut." Locality located in former oil field about $0.80 \mathrm{~km} \mathrm{~S}$ of Imperial Highway $0.45 \mathrm{~km} E$ of its intersection with Beach Blvd. and $0.93 \mathrm{~km}$ SE of intersection of Beach Blvd and Imperial Highway, West Coyote Hills, Fullerton, Orange County, CA. Site stratigraphically about $66 \mathrm{~m}$ above base of exposed "San Pedro" Formation. Collected by Matthew Phillips, 9/11/97.

Mollusca

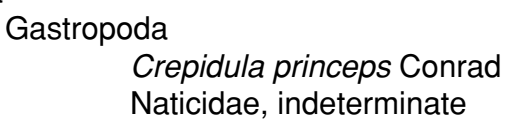

Field No.: RMW/ MLP 103. "Medium sand and siltstone. San Pedro Formation. Location: base of main buttress." Locality located in former oil field about $1.05 \mathrm{~km} \mathrm{~S}$ of Imperial Highway $0.39 \mathrm{~km} \mathrm{E}$ of its intersection with Beach Blvd. and $1.12 \mathrm{~km}$ SE of intersection of Beach Blvd and Imperial Highway, West Coyote Hills, Fullerton, Orange County, CA. Site stratigraphically about $50 \mathrm{~m}$ above base of exposed "San Pedro" Formation. Collected by Matthew Phillips, 10/2/97.

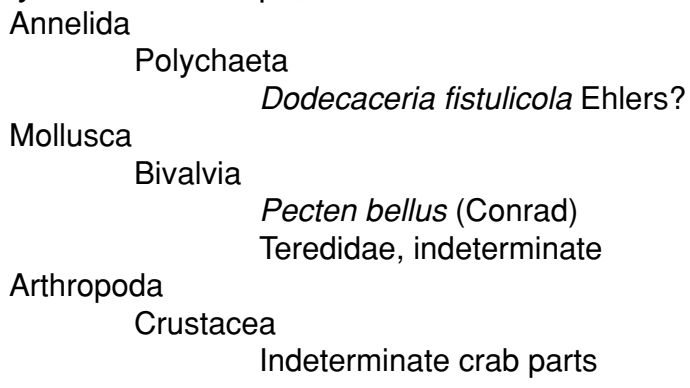


Field No.: RMW/ MLP 111. "Black and gray siltstone and sandstone. San Pedro Formation. Location: toe of third ridge." Locality located in former oil field about $0.87 \mathrm{~km} \mathrm{~S}$ of Imperial Highway $0.13 \mathrm{~km}$ E of its intersection with Beach Blvd. and $0.88 \mathrm{~km}$ SSE of intersection of Beach Blvd and Imperial Highway, West Coyote Hills, Fullerton, Orange County, CA. Site stratigraphically about $66 \mathrm{~m}$ above base of exposed "San Pedro" Formation. Collected by Matthew Phillips, 10/28/97.

Mollusca

Bivalvia

Gastropoda

Cardiidae, indeterminate

Crepidula princeps Conrad

Field No.: RMW/MLP 116. "Medium sand. San Pedro Formation. Location: Ridge 3, middle." Locality located in former oil field about $0.96 \mathrm{~km} \mathrm{~S}$ of Imperial Highway $0.15 \mathrm{~km}$ E of its intersection with Beach Blvd. and $0.97 \mathrm{~km}$ SSE of intersection of Beach Blvd and Imperial Highway, West Coyote Hills, Fullerton, Orange County, CA. Site stratigraphically about $66 \mathrm{~m}$ above base of exposed "San Pedro" Formation. Collected by Matthew Phillips, 11/21/97.

Mollusca

Bivalvia

Lucinoma annulata (Reeve)

Tresus sp., cf. T. nuttallii (Conrad)

Field No.: RMW/MLP 120. "Gray to reddish medium sand. San Pedro Formation. Location: base of ridge to right of Canyon 3." Locality located in former oil field about $0.94 \mathrm{~km} \mathrm{~S}$ of Imperial Highway $0.13 \mathrm{~km} \mathrm{E}$ of its intersection with Beach Blvd. and $0.96 \mathrm{~km}$ SSE of intersection of Beach Blvd and Imperial Highway, West Coyote Hills, Fullerton, Orange County, CA. Site stratigraphically about $50 \mathrm{~m}$ above base of exposed "San Pedro" Formation. Collected by Matthew Phillips, 12/16/97. Middle fauna.

Mollusca

Bivalvia

Cardiidae, indeterminate

Chlamys sp., cf. C. hastata (Sowerby)

Cyclocardia sp., cf. C. occidentalis (Conrad)

Lucinidae, indeterminate

Pandora wardiana Adams

Patinopecten caurinus (Gould)

Pododesmus macrochisma (Deshayes)

Gastropoda

Saxidomus nuttalli? (Conrad)

Crepidula princeps Conrad

Naticidae, indeterminate

Field No.: RMW/MLP 123. "Medium to fine sand. San Pedro Formation. Location: right of Canyon 3." Locality located in former oil field about $0.94 \mathrm{~km}$ S of Imperial Highway $0.12 \mathrm{~km}$ E of its intersection with Beach Blvd. and $0.95 \mathrm{~km}$ SE of intersection of Beach Blvd and Imperial Highway, West Coyote Hills, Fullerton, Orange County, CA. Site stratigraphically about $50 \mathrm{~m}$ above base of exposed "San Pedro" Formation. Collected by Matthew Phillips, 1/8/98.

Mollusca

Bivalvia

Cardiidae, indeterminate

Compsomyax? sp.

Cyclocardia sp., cf. C. occidentalis (Conrad)

Gastropoda

Tresus sp., cf. T. nuttalli (Conrad)

Crepidula sp., cf. C. princeps Conrad 
Field No.: RMW/MLP 135. "Reddish siltstone. La Habra Formation. Location: above main cut." Locality located in former oil field about $1.13 \mathrm{~km} \mathrm{~S}$ of Imperial Highway $0.38 \mathrm{~km}$ W of its intersection with Beach Blvd. and $1.18 \mathrm{~km} \mathrm{SSW}$ of intersection of Beach Blvd and Imperial Highway, West Coyote Hills, Fullerton, Orange County, CA. Site stratigraphically about $50 \mathrm{~m}$ above base of exposed "San Pedro" Formation. Collected by Matthew Phillips, 3/3/98.

Mollusca

Bivalvia

Chlamys hastata (Sowerby)

Chlamys opuntia (Dall)

Modiolus sp.

Pododesmus macrochisma (Deshayes)

Field No.: RMW/MLP 140. "Siltstone and reddish sand. San Pedro Formation. Location: Canyon 6, left side of main platen, elevation 300' [91 m]." Locality located in former oil field about $0.97 \mathrm{~km} S$ of Imperial Highway $0.18 \mathrm{~km} \mathrm{~W}$ of its intersection with Beach Blvd. and $1.00 \mathrm{~km} \mathrm{SW}$ of intersection of Beach Blvd and Imperial Highway, West Coyote Hills, Fullerton, Orange County, CA. Site stratigraphically about 2 to $4 \mathrm{~m}$ above base of exposed "San Pedro" Formation. Collected by Matthew Phillips, 3/18-19/98. Middle fauna.

Annelida

Polychaeta

Mollusca

Serpulidae, indeterminate

Bivalvia

Chlamys sp.

Glycymeris septentrionalis (Middendorff)

Macoma sp., cf. M. moesta Carpenter

Nuculana taphria (Dall)

Nutricola sp.

Ostrea? sp.

Pandora wardiana Adams

Panope abrupta (Conrad)?

Patinopecten caurinus (Gould)

Pododesmus macrochisma (Deshayes)

Gastropoda

Astyris gausapata (Gould)

Bittium sp.

Boreotrophon sp., cf. B. pedroana (Arnold)

Calyptraea sp. (flat)

Crepidula princeps Conrad

Epitonium sp.

Lacuna? sp.

Nassarius fossatus (Gould)

Nassarius mendicus (Gould)

Nassarius perpinguis (Hinds)

Neptunea tabulata (Baird)

Neverita reclusiana (Deshayes)

Ocenebra foveolata (Hinds)

Olivella baetica Carpenter

Olivella biplicata (Sowerby)

Ophiodermella inermis (Reeve)

Scaphopoda

Dentalium pretiosum Sowerby

Echinodermata

Echinoidea

Dendraster venturensis Kew 
Field No.: RMW/MLP 141. "Gray siltstone and fine sand. San Pedro Formation. Location: Canyon 7." Locality located in former oil field about $0.96 \mathrm{~km} \mathrm{~S}$ of Imperial Highway $0.54 \mathrm{~km} \mathrm{~W}$ of its intersection with Beach Blvd. and $1.12 \mathrm{~km}$ SSW of intersection of Beach Blvd and Imperial Highway, West Coyote Hills, Fullerton, Orange County, CA. Site stratigraphically about $8 \mathrm{~m}$ above base of exposed "San Pedro" Formation. Collected by Matthew Phillips, 4/8/98.

Arthropoda

Crustacea

Coronula? sp.

Field No.: RMW/MLP 146. "Sandstone overlying siltstone. San Pedro Formation. Location: above Ridge 6." Locality located in former oil field about $1.12 \mathrm{~km} \mathrm{~S}$ of Imperial Highway $0.35 \mathrm{~km} \mathrm{~W}$ of its intersection with Beach Blvd. and $1.18 \mathrm{~km}$ SSW of intersection of Beach Blvd and Imperial Highway, West Coyote Hills, Fullerton, Orange County, CA. Site stratigraphically about $50 \mathrm{~m}$ above base of exposed "San Pedro" Formation. Collected by Matthew Phillips, 5/5/98. Middle fauna.

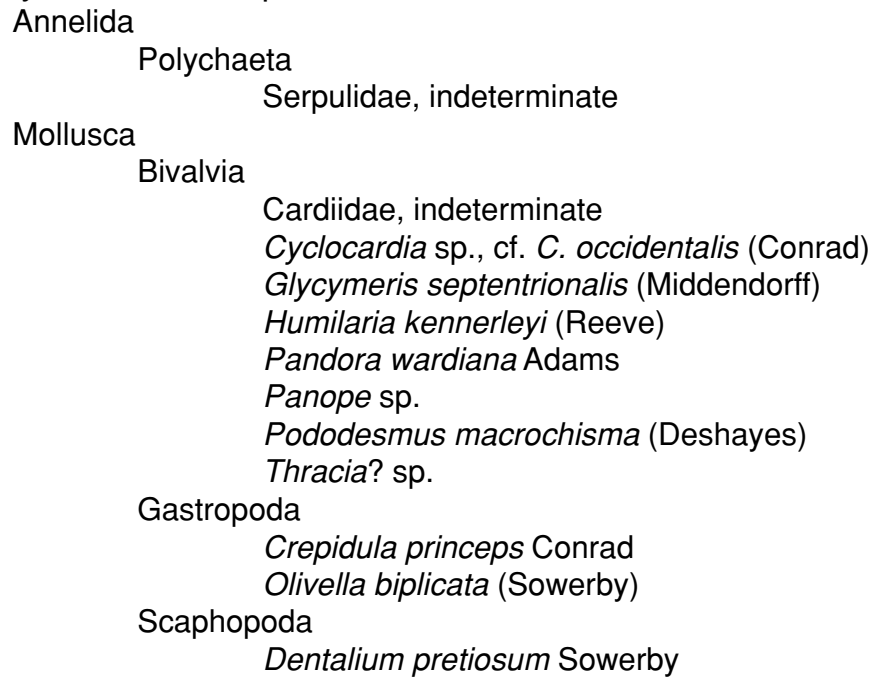

Field No.: RMW/MLP 148. "Medium to fine sand. San Pedro Formation. Location: at toe of Ridge 2 on finished slope." Locality located in former oil field about $0.51 \mathrm{~km} \mathrm{~S}$ of Imperial Highway $0.31 \mathrm{~km} E$ of its intersection with Beach Blvd. and $0.60 \mathrm{~km}$ SSE of intersection of Beach Blvd and Imperial Highway, West Coyote Hills, Fullerton, Orange County, CA. Site stratigraphically about $69 \mathrm{~m}$ above base of exposed "San Pedro" Formation. Collected by Matthew Phillips, 5/20/98.

Mollusca

Bivalvia

Glycymeris septentrionalis (Middendorff)

Lucinoma annulata (Reeve)

Gastropoda

Pecten bellus (Conrad)

Crepidula princeps Conrad

Fusinus sp., cf. F. barbarensis (Trask)

Olivella baetica Carpenter

Olivella biplicata (Sowerby)

Nassarius sp.

Naticidae, indeterminate

Scaphopoda

Turritella cooperi Carpenter

Dentalium neohexagonum Pilsbry \& Sharp

Dentalium sp.

Echinodermata

Echinoidea

Dendraster sp.

Field No.: RMW/MWT 001. "White sand. San Pedro Formation. Location: east end of Idaho Street, elevation 170' [50 m]." Locality located in former oil field about $1.13 \mathrm{~km} \mathrm{~S}$ of Imperial Highway $0.61 \mathrm{~km} E$ of its 
intersection with Beach Blvd. and $1.30 \mathrm{~km}$ SE of intersection of Beach Blvd and Imperial Highway, West Coyote Hills, Fullerton, Orange County, CA. Site stratigraphically about $78 \mathrm{~m}$ above base of exposed "San Pedro" Formation. Collected by Michael Thompson, 5/28/98.

Mollusca

Bivalvia Gastropoda

Thracia? sp.

Tresus sp., cf. T. nuttallii (Conrad)

Crepidula princeps Conrad

Field No.: RMW/MWT 003. "White sand. San Pedro Formation. Location: near water tower, elevation 450' [140 m]." Locality located in former oil field about $0.94 \mathrm{~km} \mathrm{~S}$ of Imperial Highway $0.14 \mathrm{~km} \mathrm{E}$ of its intersection with Beach Blvd. and $0.96 \mathrm{~km}$ SSE of intersection of Beach Blvd and Imperial Highway, West Coyote Hills, Fullerton, Orange County, CA. Site stratigraphically about $50 \mathrm{~m}$ above base of exposed "San Pedro" Formation. Collected by Michael Thompson, 6/4/98.

Mollusca

Bivalvia

Gastropoda

Pecten bellus Conrad

Tresus nuttallii (Conrad)

Crepidula princeps Conrad

Fusinus sp., cf. F. barbarensis (Trask)

Megasurcula carpenteriana (Gabb)

Field No.: RMW/MWT 004. "White sand. San Pedro Formation. Location: near golf coarse, elevation 300' 450' [90 - $140 \mathrm{~m}$ ]." Locality located in former oil field about $0.54 \mathrm{~km} \mathrm{~S}$ of Imperial Highway $0.27 \mathrm{~km} \mathrm{E}$ of its intersection with Beach Blvd. and $0.60 \mathrm{~km}$ SE of intersection of Beach Blvd and Imperial Highway, West Coyote Hills, Fullerton, Orange County, CA. Site stratigraphically about $66 \mathrm{~m}$ above base of exposed "San Pedro" Formation. Collected by Michael Thompson, 6/11-15/98. Middle fauna.

Mollusca

Bivalvia

Cardiidae, indeterminate
Lucinoma annulata (Reeve)
Patinopecten caurinus (Gould)
Pecten bellus Conrad
Tellinidae?, indeterminate
Tresus sp., cf. T. nuttallii (Conrad)
Gastropoda
Crepidula princeps Conrad
Naticidae, indeterminate
Neptunea tabulata (Baird)
Olivella biplicata (Sowerby)
Ophiodermella inermis (Reeve)
Echinodermata
Echinodea
Dendraster sp.

Field No.: RMW/MWT 010. "Tan to white siltstone and sandstone. San Pedro Formation. Location: Canyon 1, 2, 3, and 5, elevation 400' [120 m]." Locality located in former oil field about $0.57 \mathrm{~km}$ S of Imperial Highway $0.42 \mathrm{~km} E$ of its intersection with Beach Blvd. and $0.70 \mathrm{~km} \mathrm{SE}$ of intersection of Beach Blvd and Imperial Highway, West Coyote Hills, Fullerton, Orange County, CA. Site stratigraphically about $66 \mathrm{~m}$ above base of exposed "San Pedro" Formation. Collected by Michael Thompson, 6/26/98.

Mollusca

Bivalvia

Lucinoma annulata (Reeve)

Patinopecten sp.

Gastropoda

Pecten bellus Conrad

Boreotrophon sp., cf. B. multicostatus (Eschscholtz)

Crepidula princeps Conrad 
Fusinus sp., cf. F. barbarensis (Trask)

Naticidae, indeterminate

Olivella biplicata (Sowerby)

Field No.: RMW/MWT 012. "Sandstone and siltstone. San Pedro Formation. Location: Canyons 1, 2, and 3, elevation 400' [120 m]." Locality located in former oil field about $0.58 \mathrm{~km} \mathrm{~S}$ of Imperial Highway $0.46 \mathrm{~km} \mathrm{E}$ of its intersection with Beach Blvd. and $0.73 \mathrm{~km}$ SE of intersection of Beach Blvd and Imperial Highway, West Coyote Hills, Fullerton, Orange County, CA. Site stratigraphically about $41 \mathrm{~m}$ above base of exposed "San Pedro" Formation. Collected by Michael Thompson, 7/10/98.

Mollusca

Bivalvia

Lucinoma annulata (Reeve)

Pecten bellus Conrad

Gastropoda

Thracia? sp.

Conus californicus Reeve

Neverita reclusiana (Deshayes)

Olivella biplicata (Sowerby)

Field No.: RMW/MWT 013. "Sandstone. San Pedro Formation. Location: Canyon 2, elevation 450'." Locality located in former oil field about $0.60 \mathrm{~km}$ S of Imperial Highway $0.48 \mathrm{~km}$ E of its intersection with Beach Blvd. and $0.80 \mathrm{~km}$ SE of intersection of Beach Blvd and Imperial Highway, West Coyote Hills, Fullerton, Orange County, CA. Site stratigraphically about $66 \mathrm{~m}$ above base of exposed "San Pedro" Formation. Collected by Michael Thompson, 7/15/98.

Mollusca

Bivalvia Gastropoda

Lucinoma annulata (Reeve)

Pecten bellus Conrad

Conus californicus Reeve

Crepidula princeps Conrad

Fusinus sp., cf. F. barbarensis (Trask)

Naticidae, indeterminate

Olivella biplicata (Sowerby)

Turritella cooperi Carpenter

Field No.: RMW/MWT 014. "Tan sandstone. San Pedro Formation. Location: Canyon 2, elevation 450' [140 m]." Locality located in former oil field about $0.59 \mathrm{~km} \mathrm{~S}$ of Imperial Highway $0.47 \mathrm{~km} E$ of its intersection with Beach Blvd. and $0.77 \mathrm{~km}$ SE of intersection of Beach Blvd and Imperial Highway, West Coyote Hills, Fullerton, Orange County, CA. Site stratigraphically about $66 \mathrm{~m}$ above base of exposed "San Pedro" Formation. Collected by Michael Thompson, 7/20/98.

Mollusca

Bivalvia

Lucinoma annulata (Reeve)

Field No.: RMW/POM 035. "Sand. San Pedro Formation. Location: along Idaho Street, north of bridge." Locality located in former oil field about $0.93 \mathrm{~km} \mathrm{~S}$ of Imperial Highway $0.69 \mathrm{~km}$ E of its intersection with Beach Blvd. and $1.17 \mathrm{~km}$ SE of intersection of Beach Blvd and Imperial Highway, West Coyote Hills, Fullerton, Orange County, CA. Site stratigraphically about $66 \mathrm{~m}$ above base of exposed "San Pedro" Formation. Collected by Patrick Maxon, 3/11/97.

Mollusca

Bivalvia

Pecten bellus Conrad

Field No.: RMW/POM 036. "Beige sand and sandstone. San Pedro Formation. Location: west of Idaho Street in Canyon 1." Locality located in former oil field about $0.92 \mathrm{~km} S$ of Imperial Highway $0.85 \mathrm{~km} E$ of its intersection with Beach Blvd. and $1.24 \mathrm{~km}$ SE of intersection of Beach Blvd and Imperial Highway, West Coyote Hills, Fullerton, Orange County, CA. Site stratigraphically about $41 \mathrm{~m}$ above base of exposed "San 
Pedro" Formation. Collected by Patrick Maxon, 3/18/97.

Mollusca

Bivalvia

Clinocardium? sp.

Field No.: RMW/SEC 009. "Coquina and loose sand with pebbles. San Pedro Formation. Location: below pads 64 and 65 in key cut, elevation 300' [90 m]." Locality located in former oil field about $1.17 \mathrm{~km} \mathrm{~S}$ of Imperial Highway $0.22 \mathrm{~km} \mathrm{~W}$ of its intersection with Beach Blvd. and $1.19 \mathrm{~km} \mathrm{SSW}$ of intersection of Beach Blvd and Imperial Highway, West Coyote Hills, Fullerton, Orange County, CA. Site stratigraphically about 50 m above base of exposed "San Pedro" Formation. Collected by Skip Clay, 9/5/97.

Mollusca

Bivalvia

Gastropoda

Pecten bellus Conrad

Crepidula sp., cf. C. princeps Conrad

Field No.: RMW/SEC 028. "Gray-blue siltstone. San Pedro Formation. Location: club house, elevation 330" [100 m]." Locality located in former oil field about $0.47 \mathrm{~km} \mathrm{~S}$ of Imperial Highway $0.11 \mathrm{~km} E$ of its intersection with Beach Blvd. and $0.48 \mathrm{~km}$ SSE of intersection of Beach Blvd and Imperial Highway, West Coyote Hills, Fullerton, Orange County, CA. Site stratigraphically about $66 \mathrm{~m}$ above base of exposed "San Pedro" Formation. Collected by Skip Clay, 11/5/97.

Mollusca

Bivalvia

Gastropoda

Cardiidae, indeterminate

Cyclocardia sp., cf. C. occidentalis (Conrad)

Crepidula princeps Conrad

Polinices lewisii (Gould)?

Field No.: RMW/SRA 029. "Medium grain sandstone. San Pedro Formation. Location: Ridge 1, elevation 430' [130 m]." Locality located in former oil field about $1.02 \mathrm{~km} \mathrm{~S}$ of Imperial Highway $0.57 \mathrm{~km}$ E of its intersection with Beach Blvd. and $1.18 \mathrm{~km}$ SE of intersection of Beach Blvd and Imperial Highway, West Coyote Hills, Fullerton, Orange County, CA. Site stratigraphically about $78 \mathrm{~m}$ above base of exposed "San Pedro" Formation. Collected by Scott Armstrong, 3/26/97.

Mollusca

Bivalvia

Pecten bellus Conrad

Field No.: RMW/SRA 033. "Green silt. San Pedro Formation. Location: Ridge one, elevation 248 ' [75 m]." Locality located in former oil field about $0.70 \mathrm{~km} \mathrm{~S}$ of Imperial Highway $0.62 \mathrm{~km} \mathrm{E}$ of its intersection with Beach Blvd. and $0.95 \mathrm{~km}$ SE of intersection of Beach Blvd and Imperial Highway, West Coyote Hills, Fullerton, Orange County, CA. Site stratigraphically about $66 \mathrm{~m}$ above base of exposed "San Pedro" Formation. Collected by Scott Armstrong, 5/6/97.

Mollusca

Bivalvia

Cardiidae, indeterminate

Cyclocardia sp., cf. C. occidentalis (Conrad)

Gastropoda

Astyris gausapata (Gould)

Crepidula sp.

Nassarius sp., cf. N. mendicus (Gould)

Olivella biplicata (Sowerby)

Field No.: RMW/SRA 037. "Mudstone with charcoal. Coyote Hills Formation. Location: 100' southwest of Well 335, elevation 495' [150 m]." Locality located in former oil field about $1.15 \mathrm{~km} \mathrm{~S}$ of Imperial Highway $0.48 \mathrm{~km}$ E of its intersection with Beach Blvd. and $1.22 \mathrm{~km}$ SE of intersection of Beach Blvd and Imperial Highway, West Coyote Hills, Fullerton, Orange County, CA. Site stratigraphically from 98 to $107 \mathrm{~m}$ above 
base of exposed "San Pedro" Formation in Coyote Hills Formation. Collected by Scott Armstrong, 5/21/97. Restricted fauna.

Mollusca

Bivalvia

Macoma sp.

Tagelus sp., cf. T. subteres (Conrad)

Field No.: RMW/SRA 040. "Concretion in very fine white sand. San Pedro Formation. Location: 100' east of Well MC20, elevation 430' [130 m]." Locality located in former oil field about $1.17 \mathrm{~km}$ S of Imperial Highway $0.61 \mathrm{~km}$ E of its intersection with Beach Blvd. and $1.30 \mathrm{~km}$ SE of intersection of Beach Blvd and Imperial Highway, West Coyote Hills, Fullerton, Orange County, CA. Site stratigraphically about $78 \mathrm{~m}$ above base of exposed "San Pedro" Formation. Collected by Scott Armstrong, 6/2/97.

Mollusca

Bivalvia

Cardiidae, indeterminate

Field No.: RMW/SRA 051. '90' N of Well \#371; elevation 469' [143 m]. Gray medium sand. San Pedro Formation." Locality located in former oil field about $0.58 \mathrm{~km} \mathrm{~S}$ of Imperial Highway $0.40 \mathrm{~km}$ E of its intersection with Beach Blvd. and $0.71 \mathrm{~km}$ SE of intersection of Beach Blvd and Imperial Highway, West Coyote Hills, Fullerton, Orange County, CA. Site stratigraphically about $66 \mathrm{~m}$ above base of exposed "San Pedro" Formation. Collected by Scott Armstrong, 7/11/97.

Mollusca

Bivalvia
Nuculana taphria (Dall)
Gastropoda
Astyris gausapata (Gould)
Conus californicus Reeve
Fusinus sp., cf. F. barbarensis (Trask)
Nassarius mendicus (Gould)
Nassarius sp., cf. N. perpinguis (Hinds)
Naticidae, indeterminate
Olivella biplicata (Sowerby)
Ophiodermella inermis (Reeve)

Field No.: RMW/SRA 070. "Pad 57; elevation 310' [95 m]. Greenish-gray mudstone. San Pedro Formation." Locality located in former oil field about $0.51 \mathrm{~km}$ S of Imperial Highway $0.26 \mathrm{~km} E$ of its intersection with Beach Blvd. and $0.56 \mathrm{~km}$ SE of intersection of Beach Blvd and Imperial Highway, West Coyote Hills, Fullerton, Orange County, CA. Site stratigraphically about $54 \mathrm{~m}$ above base of exposed "San Pedro" Formation. Collected by Scott Armstrong, 9/2/97. Mollusca

Bivalvia

Modiolus sp.

Gastropoda

Panope abrupta (Conrad)

Calyptraea sp.

Crepidula sp.

Field No.: RMW/SRA 079. "Tan medium grain sand. San Pedro Formation. Location: pad 66, elevation 351' [107 m]." Locality located in former oil field about $0.51 \mathrm{~km} \mathrm{~S}$ of Imperial Highway $0.50 \mathrm{~km} E$ of its intersection with Beach Blvd. and $0.72 \mathrm{~km}$ SE of intersection of Beach Blvd and Imperial Highway, West Coyote Hills, Fullerton, Orange County, CA. Site stratigraphically about $69 \mathrm{~m}$ above base of exposed "San Pedro" Formation. Collected by Scott Armstrong, 6/2/97.

Mollusca

Bivalvia

Pecten bellus (Conrad)

Field No.: RMW/SRA 082. "Tan and gray silt. San Pedro Formation. Location: club house parking lot." Locality located in former oil field about $0.61 \mathrm{~km} \mathrm{~S}$ of Imperial Highway $0.12 \mathrm{~km}$ E of its intersection with Beach Blvd. and $0.63 \mathrm{~km}$ SSE of intersection of Beach Blvd and Imperial Highway, West Coyote Hills, Fuller- 
ton, Orange County, CA. Site stratigraphically about $66 \mathrm{~m}$ above base of exposed "San Pedro" Formation. Collected by Scott Armstrong, 10/27/97.

Mollusca

Bivalvia

Cardiidae, indeterminate

Clinocardium? sp.

Lucinoma annulata (Reeve)

Macoma? sp.

Semele? sp.

Gastropoda

Tresus? sp.

Calyptraea sp.

Crepidula sp.

Nassarius sp.

Field No.: RMW/SRA 083. "Concretions in white sand. San Pedro Formation. Location: $30 \mathrm{~m}$ north of Well 92." Locality located in former oil field about $0.87 \mathrm{~km} \mathrm{~S}$ of Imperial Highway $0.15 \mathrm{~km}$ E of its intersection with Beach Blvd. and $0.88 \mathrm{~km}$ SSE of intersection of Beach Blvd and Imperial Highway, West Coyote Hills, Fullerton, Orange County, CA. Site stratigraphically about $66 \mathrm{~m}$ above base of exposed "San Pedro" Formation. Collected by Scott Armstrong, 10/29/97.

Mollusca

Bivalvia

Tresus nuttalli (Conrad)

Field No.: RMW/SRA 111. "White and orange sand. San Pedro Formation. Location: Canyon 7 under turbidite (8' stratigraphically)." Locality located in former oil field about $0.97 \mathrm{~km}$ S of Imperial Highway $0.71 \mathrm{~km}$ W of its intersection with Beach Blvd. and $1.19 \mathrm{~km} \mathrm{SSW}$ of intersection of Beach Blvd and Imperial Highway,

West Coyote Hills, Fullerton, Orange County, CA. Site stratigraphically from 2 to $4 \mathrm{~m}$ above base of exposed "San Pedro" Formation. Collected by Scott Armstrong, 3/17/98. Middle fauna.

Mollusca

Bivalvia

Pandora wardiana Adams

Patinopecten caurinus (Gould)

Field No.: RMW/SRA 112. "Tan siltstone. San Pedro Formation. Location: northeast facing slope in back of Canyon 7, elevation 328 [100 m].' Locality located in former oil field about $1.04 \mathrm{~km}$ S of Imperial Highway $0.61 \mathrm{~km} \mathrm{~W}$ of its intersection with Beach Blvd. and $1.21 \mathrm{~km} \mathrm{SSW}$ of intersection of Beach Blvd and Imperial Highway, West Coyote Hills, Fullerton, Orange County, CA. Site stratigraphically about 2 to $4 \mathrm{~m}$ above base of exposed "San Pedro" Formation. Collected by Scott Armstrong, 3/17/98.

Mollusca

Gastropoda

Polinices sp., cf. P. draconis (Dall)

Field No.: RMW/SRA 113. "Gray medium sand with concretions. San Pedro Formation. Location: $30 \mathrm{~m}$ north of Well MC92." Locality located in former oil field about $0.88 \mathrm{~km} \mathrm{~S} \mathrm{of} \mathrm{Imperial} \mathrm{Highway} 0.14 \mathrm{~km} E$ of its intersection with Beach Blvd. and $0.90 \mathrm{~km}$ SSE of intersection of Beach Blvd and Imperial Highway, West Coyote Hills, Fullerton, Orange County, CA. Site stratigraphically about $66 \mathrm{~m}$ above base of exposed "San Pedro" Formation. Collected by Scott Armstrong, 3/17/98.

Mollusca

Bivalvia

Gastropoda

Saxidomus nuttalli Conrad

Conus californicus Reeve

Field No.: RMW/SRA 118. "Tan siltstone. San Pedro Formation. Location: south of Canyon 6 (slide)." Locality located in former oil field about $1.06 \mathrm{~km} \mathrm{~S}$ of Imperial Highway $0.23 \mathrm{~km} \mathrm{~W}$ of its intersection with Beach Blvd. and $1.08 \mathrm{~km}$ SSW of intersection of Beach Blvd and Imperial Highway, West Coyote Hills, Fullerton, Orange County, CA. Site stratigraphically about $50 \mathrm{~m}$ above base of exposed "San Pedro" Forma- 
tion. Collected by Scott Armstrong, 4/9/98. Middle fauna (?).

Mollusca

Bivalvia

Chlamys sp., cf. C. hastata (Sowerby)

Chlamys sp.

Patinopecten sp.

Pododesmus macrochisma (Deshayes)

Field No.: RMW/SRA 120. "Fine brown silt. San Pedro Formation. Location: north facing slope, back of Canyon 7, elevation 285' [87 m]." Locality located in former oil field about $1.06 \mathrm{~km} \mathrm{~S}$ of Imperial Highway 0.23 $\mathrm{km} \mathrm{W}$ of its intersection with Beach Blvd. and $1.08 \mathrm{~km} \mathrm{SSW}$ of intersection of Beach Blvd and Imperial Highway, West Coyote Hills, Fullerton, Orange County, CA. Site stratigraphically about $8 \mathrm{~m}$ above base of exposed "San Pedro" Formation. Collected by Scott Armstrong, 4/10/98.

Annelida

Polychaeta

Serpulidae, indeterminate

Field No.: RMW/SRA 121. "Tan silt. San Pedro Formation. Location: south facing slope, back of Canyon 7, elevation 280' [85 m]." Locality located in former oil field about $0.99 \mathrm{~km}$ S of Imperial Highway $0.68 \mathrm{~km}$ W of its intersection with Beach Blvd. and $1.22 \mathrm{~km}$ SSW of intersection of Beach Blvd and Imperial Highway, West Coyote Hills, Fullerton, Orange County, CA. Site stratigraphically about $8 \mathrm{~m}$ above base of exposed "San Pedro" Formation. Collected by Scott Armstrong, 4/10/98.

Arthropoda

Crustacea

Indeterminate crab claw

Field No.: RMW/SRA 126. "Gray silt. San Pedro Formation. Location: club house, ridge 3." Locality located in former oil field about $0.64 \mathrm{~km}$ S of Imperial Highway $0.15 \mathrm{~km}$ E of its intersection with Beach Blvd. and $0.65 \mathrm{~km}$ SSE of intersection of Beach Blvd and Imperial Highway, West Coyote Hills, Fullerton, Orange County, CA. Site stratigraphically about $66 \mathrm{~m}$ above base of exposed "San Pedro" Formation. Collected by Scott Armstrong, 4/16/98.

Mollusca

Gastropoda

Crepidula princeps Conrad

Field No.: RMW/SRA 127. "Gray silt. San Pedro Formation. Location: north end of Ridge 3, elevation 325' [99 m]." Locality located in former oil field about $0.65 \mathrm{~km} \mathrm{~S}$ of Imperial Highway $0.15 \mathrm{~km} \mathrm{E}$ of its intersection with Beach Blvd. and $0.67 \mathrm{~km}$ SSE of intersection of Beach Blvd and Imperial Highway, West Coyote Hills, Fullerton, Orange County, CA. Site stratigraphically about $66 \mathrm{~m}$ above base of exposed "San Pedro" Formation. Collected by Scott Armstrong, 4/16/98. Middle fauna.

Mollusca

Bivalvia

Cardiidae, indeterminate

Cyclocardia sp., cf. C. occidentalis (Conrad)

Patinopecten caurinus (Gould)

Gastropoda

Pododesmus macrochisma (Deshayes)

Crassispira zizyphus Berry

Naticidae, indeterminate

Field No.: RMW/SRA 128. "Gray silt. San Pedro Formation. Location: Well 92, elevation 396' [121 m]." Locality located in former oil field about $0.88 \mathrm{~km}$ S of Imperial Highway $0.18 \mathrm{~km}$ E of its intersection with Beach Blvd. and $0.91 \mathrm{~km}$ SSE of intersection of Beach Blvd and Imperial Highway, West Coyote Hills, Fullerton, Orange County, CA. Site stratigraphically about $66 \mathrm{~m}$ above base of exposed "San Pedro" Formation. Collected by Scott Armstrong, 4/21/98.

Mollusca

Bivalvia

Pecten bellus (Conrad) 
Field No.: RMW/SRA 132. "Gray silt. San Pedro Formation. Location: Ridge 3, near north end." Locality located in former oil field about $0.62 \mathrm{~km} \mathrm{~S}$ of Imperial Highway $0.13 \mathrm{~km}$ E of its intersection with Beach Blvd. and $0.65 \mathrm{~km}$ SSE of intersection of Beach Blvd and Imperial Highway, West Coyote Hills, Fullerton, Orange County, CA. Site stratigraphically about $54 \mathrm{~m}$ above base of exposed "San Pedro" Formation. Collected by Scott Armstrong, 4/27/98.

Mollusca

Gastropoda

Crepidula princeps (Conrad)

Field No.: RMW/SRA 135. "Greenish gray silt. San Pedro Formation. Location: north facing slope far back of Canyon 7, elevation 450' [140 m]." Locality located in former oil field about $1.05 \mathrm{~km} \mathrm{~S}$ of Imperial Highway $0.58 \mathrm{~km} \mathrm{~W}$ of its intersection with Beach Blvd. and $1.21 \mathrm{~km} \mathrm{SSW}$ of intersection of Beach Blvd and Imperial Highway, West Coyote Hills, Fullerton, Orange County, CA. Site stratigraphically about $8 \mathrm{~m}$ above base of exposed "San Pedro" Formation. Collected by Scott Armstrong, 4/29/98. Middle fauna.

Mollusca

Bivalvia

Patinopecten caurinus (Gould)

Field No.: RMW/SRA 137. "Tan sand. San Pedro Formation. Location: Ridge 2, elevation 285 ' [87 m]." Locality located in former oil field about $0.48 \mathrm{~km} \mathrm{~S}$ of Imperial Highway $0.24 \mathrm{~km}$ E of its intersection with Beach Blvd. and $0.53 \mathrm{~km}$ SSE of intersection of Beach Blvd and Imperial Highway, West Coyote Hills, Fullerton, Orange County, CA. Site stratigraphically about $69 \mathrm{~m}$ above base of exposed "San Pedro" Formation. Collected by Scott Armstrong, 5/1/98.

Mollusca

Bivalvia

Gastropoda

Lucinoma annulata (Reeve)

Pecten bellus (Conrad)

Conus californicus Reeve

Crepidula princeps Conrad

Fusinus sp., cf. F. barbarensis (Trask)

Megasurcula carpenteriana (Gabb)

Nassarius sp.

Naticidae, indeterminate

Field No.: RMW/SSG 97-18. "Cemented sandstone. San Pedro Formation. Location: near pads 85-86, elevation 475' [145 m]." Locality located in former oil field about $0.81 \mathrm{~km}$ S of Imperial Highway $0.53 \mathrm{~km} \mathrm{E}$ of its intersection with Beach Blvd. and $0.97 \mathrm{~km}$ SE of intersection of Beach Blvd and Imperial Highway, West Coyote Hills, Fullerton, Orange County, CA. Site stratigraphically about $66 \mathrm{~m}$ above base of exposed "San Pedro" Formation. Collected by Sean Gallager, 5/30/97.

Mollusca

Bivalvia

Gastropoda

Cardiidae, indeterminate

Nassarius sp.

Turritella sp.

Field No.: RMW/SSG 97-21. "Oxidized sand and sandy mud. San Pedro Formation. Location: Pad 112, elevation 410' [125 m]." Locality located in former oil field about $0.67 \mathrm{~km}$ S of Imperial Highway $0.51 \mathrm{~km} E$ of its intersection with Beach Blvd. and $0.84 \mathrm{~km}$ SE of intersection of Beach Blvd and Imperial Highway, West Coyote Hills, Fullerton, Orange County, CA. Site stratigraphically about $66 \mathrm{~m}$ above base of exposed "San Pedro" Formation. Collected by Sean Gallager, 6/5/97.

Mollusca

Bivalvia

Pecten bellus (Conrad)

Arthropoda

Crustacea

Indeterminate crab parts 
Field No.: RMW/SSG 97-30. "Lot 108; elevation 390' [120 m]. Massive mudstone. Coyote Hills Formation." Locality located in former oil field about $0.58 \mathrm{~km}$ S of Imperial Highway $0.39 \mathrm{~km}$ E of its intersection with Beach Blvd. and $0.71 \mathrm{~km}$ SE of intersection of Beach Blvd and Imperial Highway, West Coyote Hills, Fullerton, Orange County, CA. Site stratigraphically between 98 and 107 m above base of exposed "San Pedro" Formation in the Coyote Hills Formation. Collected by Sean Gallager, 7/9/97. Restricted fauna. Mollusca

Bivalvia

Macoma? sp. Indeterminate bivalves

Field No.: RMW/SSG 97-41. 'Welded sandstone. San Pedro Formation. Location: 100 ' [30 m] north of pads 55-56, elevation 300' [90 m]." Locality located in former oil field about $0.52 \mathrm{~km} \mathrm{~S}$ of Imperial Highway $0.25 \mathrm{~km}$ E of its intersection with Beach Blvd. and $0.60 \mathrm{~km}$ SE of intersection of Beach Blvd and Imperial Highway, West Coyote Hills, Fullerton, Orange County, CA. Site stratigraphically about $66 \mathrm{~m}$ above base of exposed "San Pedro" Formation. Collected by Sean Gallager, 8/20/97.

Mollusca

Bivalvia

Gastropoda

Cardiidae, indeterminate

Panope abrupta (Conrad)

Calyptraea sp. (flat)

Nassarius sp.

Olivella biplicata (Sowerby)

Field No.: RMW/SSG 97-47. "Coarse sandstone. San Pedro Formation. Location: 75' [23 m] north of pad 60, elevation 311' [95 m]." Locality located in former oil field about $0.49 \mathrm{~km} \mathrm{~S}$ of Imperial Highway $0.36 \mathrm{~km} \mathrm{E}$ of its intersection with Beach Blvd. and $0.61 \mathrm{~km}$ SE of intersection of Beach Blvd and Imperial Highway, West Coyote Hills, Fullerton, Orange County, CA. Site stratigraphically about $66 \mathrm{~m}$ above base of exposed "San Pedro" Formation. Collected by Sean Gallager, 9/4/97.

Mollusca

Bivalvia
Pecten bellus (Conrad)
Tresus? sp.
Gastropoda
Nassarius mendicus (Gould)
Olivella biplicata (Sowerby)

Field No.: RMW/SSG 97-54. "Sandstone and unconsolidated sand. San Pedro Formation. Location: 50" [15 m] north of pads 85-86, elevation 460' [140 m]." Locality located in former oil field about $0.83 \mathrm{~km} S$ of Imperial Highway $0.50 \mathrm{~km}$ E of its intersection with Beach Blvd. and $0.98 \mathrm{~km} \mathrm{SE}$ of intersection of Beach Blvd and Imperial Highway, West Coyote Hills, Fullerton, Orange County, CA. Site stratigraphically about $66 \mathrm{~m}$ above base of exposed "San Pedro" Formation. Collected by Sean Gallager, 9/17/97.

Mollusca

Bivalvia

Pecten bellus (Conrad)

Field No.: RMW/SSG 97-58. "Medium sandstone. San Pedro Formation. Location: 9+58 (near hole 11), elevation 290' [90 m]." Locality located in former oil field about $0.42 \mathrm{~km}$ S of Imperial Highway $0.18 \mathrm{~km}$ E of its intersection with Beach Blvd. and $0.47 \mathrm{~km}$ SE of intersection of Beach Blvd and Imperial Highway, West Coyote Hills, Fullerton, Orange County, CA. Site stratigraphically about $66 \mathrm{~m}$ above base of exposed "San Pedro" Formation. Collected by Sean Gallager, 9/24/97.

Mollusca

Bivalvia

Cardiidae, indeterminate

Macoma? sp.

Gastropoda

Mytilus? sp.

Calyptraea sp. (flat)

Naticidae, indeterminate

Olivella biplicata (Sowerby) 
Field No.: RMW/SSG 97-59. "Medium sandstone. San Pedro Formation. Location: near hole 11, elevation 290' [90 m]." Locality located in former oil field about $0.44 \mathrm{~km} \mathrm{~S}$ of Imperial Highway $0.18 \mathrm{~km}$ E of its intersection with Beach Blvd. and $0.48 \mathrm{~km}$ SE of intersection of Beach Blvd and Imperial Highway, West Coyote Hills, Fullerton, Orange County, CA. Site stratigraphically about $66 \mathrm{~m}$ above base of exposed "San Pedro" Formation. Collected by Sean Gallager, 9/24/97.

Mollusca

Bivalvia

Cardiidae, indeterminate

Macoma? sp.

Gastropoda

Mytilus? sp.

Calyptraea sp. (flat)

Nassarius sp., cf. N. perpinguis (Hinds)

Olivella sp., cf. O. baetica Carpenter

Field No.: RMW/SSG 97-60. "Pad 94; elevation 430' [130 m]. Unconsolidated sand. San Pedro Formation." Locality located in former oil field about $0.78 \mathrm{~km}$ S of Imperial Highway $0.58 \mathrm{~km}$ E of its intersection with Beach Blvd. and $0.97 \mathrm{~km}$ SE of intersection of Beach Blvd and Imperial Highway, West Coyote Hills, Fullerton, Orange County, CA. Site stratigraphically about $66 \mathrm{~m}$ above base of exposed "San Pedro" Formation. Collected by Sean Gallager, 9/30/97.

Annelida

Polychaeta

Cirratulidae indeterminate

Field No.: RMW/SSG 97-61. "Unconsolidated sand. San Pedro Formation. Location: near well MC259, elevation 465' [142 m]." Locality located in former oil field about $0.92 \mathrm{~km} \mathrm{~S}$ of Imperial Highway $0.71 \mathrm{~km} E$ of its intersection with Beach Blvd. and $1.17 \mathrm{~km}$ SE of intersection of Beach Blvd and Imperial Highway, West Coyote Hills, Fullerton, Orange County, CA. Site stratigraphically about $69 \mathrm{~m}$ above base of exposed "San Pedro" Formation. Collected by Sean Gallager, 10/1/97.

Mollusca

Bivalvia

Gastropoda

Indeterminate bivalves

Crepidula sp.

Olivella biplicata (Sowerby)

Field No.: RMW/SSG 98-114. "Massive siltstone. San Pedro Formation. Location: Canyon 2, elevation 305' [93 m]." Locality located in former oil field about $0.90 \mathrm{~km} \mathrm{~S}$ of Imperial Highway $0.34 \mathrm{~km}$ E of its intersection with Beach Blvd. and $0.97 \mathrm{~km}$ SE of intersection of Beach Blvd and Imperial Highway, West Coyote Hills, Fullerton, Orange County, CA. Site stratigraphically about $8 \mathrm{~m}$ above base of exposed "San Pedro" Formation. Collected by Sean Gallager, 8/20/97.

Mollusca

Bivalvia

Chlamys sp.

Clinocardium? sp.

Gastropoda

Compsomyax? sp.

Naticidae, indeterminate

Field No.: RMW/SW 97-1357. "Sandstone. San Pedro Formation. Location: 500' west of Risner and Idaho Streets, elevation 488'." Locality located in former oil field about $1.18 \mathrm{~km} \mathrm{~S}$ of Imperial Highway $0.77 \mathrm{~km} \mathrm{E} \mathrm{of}$ its intersection with Beach Blvd. and $1.40 \mathrm{~km}$ SE of intersection of Beach Blvd and Imperial Highway, West Coyote Hills, Fullerton, Orange County, CA. Site stratigraphically about $78 \mathrm{~m}$ above base of exposed "San Pedro" Formation. Collected by Steve Wakefield, 4/25/97.

Mollusca

Bivalvia

Gastropoda

Cardiidae, indeterminate

Nassarius sp. 
Naticidae, indeterminate

Olivella biplicata (Sowerby)

Field No.: RMW/TJM 10. "Near Well \#373; elevation: 370' [110 m]. Gray silt with oxidation. San Pedro Formation." Locality located in former oil field about $0.81 \mathrm{~km} \mathrm{~S}$ of Imperial Highway $0.42 \mathrm{~km} \mathrm{~W}$ of its intersection with Beach Blvd. and $0.92 \mathrm{~km}$ SSW of intersection of Beach Blvd and Imperial Highway, West Coyote Hills, Fullerton, Orange County, CA. Site stratigraphically about $8 \mathrm{~m}$ above base of exposed "San Pedro" Formation. Collected. by Tim Matson, 6/2/98. Middle fauna.

Mollusca

Bivalvia

Patinopecten caurinus (Gould)

Field No.: RMW/TJM 20. "Near Well\#MC4. San Pedro Formation." Locality located in former oil field about $0.90 \mathrm{~km}$ S of Imperial Highway $0.33 \mathrm{~km}$ E of its intersection with Beach Blvd. and $0.96 \mathrm{~km}$ SE of intersection of Beach Blvd and Imperial Highway, West Coyote Hills, Fullerton, Orange County, CA. Site stratigraphically about 26 m above base of exposed "San Pedro" Formation. Collected by T. Matson, 6/8/98.

Mollusca

Bivalvia

Garisp.

Saxidomus? sp.

Indeterminate bivalve

Field No.: RMW/TJM 29. "Light gray siltstone. San Pedro Formation. Location: cut near edge of property, elevation 319' [97 m]." Locality located in former oil field about $0.90 \mathrm{~km} \mathrm{~S}$ of Imperial Highway $0.33 \mathrm{~km} \mathrm{~W} \mathrm{of}$ its intersection with Beach Blvd. and $0.96 \mathrm{~km} \mathrm{SSW}$ of intersection of Beach Blvd and Imperial Highway, West Coyote Hills, Fullerton, Orange County, CA. Site stratigraphically about $8 \mathrm{~m}$ above base of exposed "San Pedro" Formation. Collected by Tim Matson, 6/17/98. Middle fauna.

Mollusca

Bivalvia

Patinopecten caurinus (Gould)

Field No.: RMW/TJM 33. "Slope of key cut; elevation 283' [86 m]. Gray mudstone. San Pedro Formation." Locality located in former oil field about $0.97 \mathrm{~km} \mathrm{~S}$ of Imperial Highway $0.74 \mathrm{~km} \mathrm{~W}$ of its intersection with Beach Blvd. and $1.22 \mathrm{~km}$ SW of intersection of Beach Blvd and Imperial Highway, West Coyote Hills, Fullerton, Orange County, CA. Site stratigraphically about $17 \mathrm{~m}$ above base of exposed "San Pedro" Formation. Collected by Tim Matson, 7/1/98. Middle fauna

Mollusca

Bivalvia

Gastropoda

Patinopecten caurinus (Gould)

Indeterminate bivalves

Cryptonatica affinis (Gmelin)

Neverita reclusiana (Deshayes)

Field No.: RMW/TJM 34. "Blue and gray mudstone. San Pedro Formation. Location: key cut adjacent to Hillsborough, elevation 215' [66 m]." Locality located in former oil field about $0.98 \mathrm{~km}$ S of Imperial Highway $0.74 \mathrm{~km} \mathrm{~W}$ of its intersection with Beach Blvd. and $1.23 \mathrm{~km} \mathrm{SW}$ of intersection of Beach Blvd and Imperial Highway, West Coyote Hills, Fullerton, Orange County, CA. Site stratigraphically about $17 \mathrm{~m}$ above base of exposed "San Pedro" Formation. Collected by Tim Matson, 7/7/98.

Mollusca

Gastropoda

Polinices draconis (Dall)

Field No.: RMW/TJM 36. "Tan siltstone with gray-blue mudstone. San Pedro Formation. Location: Canyon 7, elevation 295' [90 m]." Locality located in former oil field about $1.08 \mathrm{~km} \mathrm{~S}$ of Imperial Highway $0.80 \mathrm{~km} \mathrm{E} \mathrm{of}$ its intersection with Beach Blvd. and $1.34 \mathrm{~km}$ SE of intersection of Beach Blvd and Imperial Highway, West Coyote Hills, Fullerton, Orange County, CA. Site stratigraphically about $17 \mathrm{~m}$ above base of exposed "San Pedro" Formation. Collected by Tim Matson, 7/13/1998. Middle fauna.

Mollusca 
Bivalvia

Clinocardium? sp.

Patinopecten caurinus (Gould)

Locality descriptions and faunal occurrences from Yerkes (1972). Taxonomic names have been update to conform with modern taxonomic views and adjusted to conform with specimens observed in PC collections and in photographs from Hoskins (1954).

Field No.: F3. Sec. 23, T. 3 S., R. 10 W., artificial cut 2,500' N and 820' W of SE corner of section, La Habra 7.5' Quadrangle. Collected by R. F. Yerkes. Identified by W. H. Holman (Yerkes, 1972, p. C59).

Mollusca

Gastropoda

Crepidula sp.

Field No: F-4. Sec. 23, T. 3 S., R. 10 W., artificial cut 2,450' N and 2,330' W of NW corner of section, La Habra 7.5' Quadrangle. Collected by R. F. Yerkes. Identified by W. H. Holman and J. G. Vedder (Yerkes, 1972, p. C59).

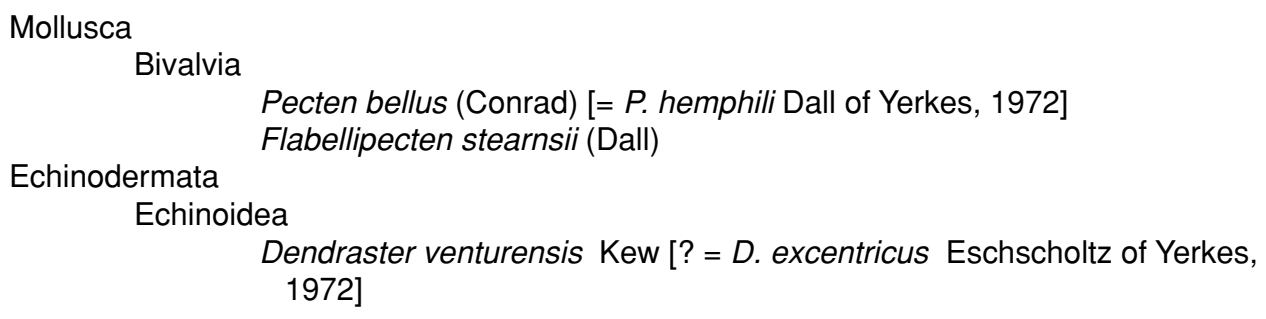

Field No: F-5. Sec. 19, T. 3 S., R. 10 W., artificial cut 1,440' S and 2,240' E of NW corner of section, La Habra 7.5' Quadrangle. Collected by R. F. Yerkes. Identified by W. H. Holman and J. G. Vedder (Yerkes, 1972, p. C59). Upper fauna.

Mollusca

Bivalvia

Argopecten ventricosus (G. B. Sowerby, II) [= A. circularis (Sowerby) of Yerkes, 1972]

Field No: F-6. Sec. 20, T. 3 S., R. 10 W., artificial cut 60' S and 1,100' E of NW corner of section, La Habra 7.5' Quadrangle. Collected by R. F. Yerkes. Identified by W. H. Holman and J. G. Vedder (Yerkes, 1972, p. C59).

Mollusca

Bivalvia

Cardiidae, indeterminate

Pecten bellus (Conrad) [= P. hemphili Dall of Yerkes, 1972]

Gastropoda Solen sp.

Crepidula princeps Conrad

Nassarius sp.

Field No.: F-7. Sec. 24, T. 3 S., R. 11 W., 350' S and 380' W of NE corner of section, La Habra 7.5' Quadrangle. Collected by C. W. Hoskins. Identified C. W. Hoskins (Yerkes, 1972, p. C59).

Mollusca

Bivalvia

Lucinoma annulata (Reeve)

Mytilus sp., cf. M. californicus Conrad

Mytilus trossulus (Gould)

Pandora sp.

Panope abrupta (Conrad)

Solen sicarius Gould

Thracia trapezoides Conrad

Gastropoda

Trachycardium quadragenarium (Conrad)

Echinodermata

Olivella biplicata (Sowerby) 
Echinoidea

Indeterminate echinoid spines

Field No.: F-7A. Sec. 24, T. 3 S., R. 11 W., artificial cut 550' S and 315' W of NE corner of section, La Habra 7.5' Quadrangle. Collected by R. F. Yerkes. Identified by W. H. Holman and J. G. Vedder (Yerkes, 1972, p. C59). Middle fauna.

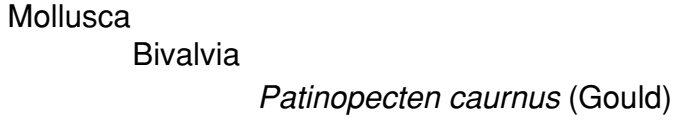

Field No.: F-8. Sec. 24, T. 3 S., R. 11 W., 125' S and 225' W of NE corner of section, La Habra 7.5' Quadrangle. Collected by C. W. Hoskins. Identified by C. W. Hoskins (Yerkes, 1972, p. C59). Middle fauna. Mollusca Bivalvia

Chlamys hastata (Sowerby)

Chlamys rubida (Hinds) [= C. hindsi (Carpenter) of Yerkes, 1972]

Compsomyax subdiaphana (Carpenter)

Cyclocardia sp., aff. C. occidentalis (Conrad) [? = C. ventricosa (Gould)

of Yerkes, 1972]

Megacrenella sp., M. columbiana Dall

Pandora wardiana Adams

Patinopecten caurnus (Gould)

Pecten bellus (Conrad)

Gastropoda

Saxidomus nuttall (Conrad)

Crepidula princeps Conrad

Lirobittium sp. [= L. rugatum (Carpenter) of Yerkes, 1972]

Neptunea tabulata (Baird)

Field No.: F-9. Sec. 17, T. 3 S., R. 10 W., artificial cut 1,340' S and 60' E of NW corner of section, La Habra 7.5' Quadrangle. Collected by C. W. Hoskins. Identified by C. W. Hoskins (Yerkes, 1972, p. C59). Upper fauna.

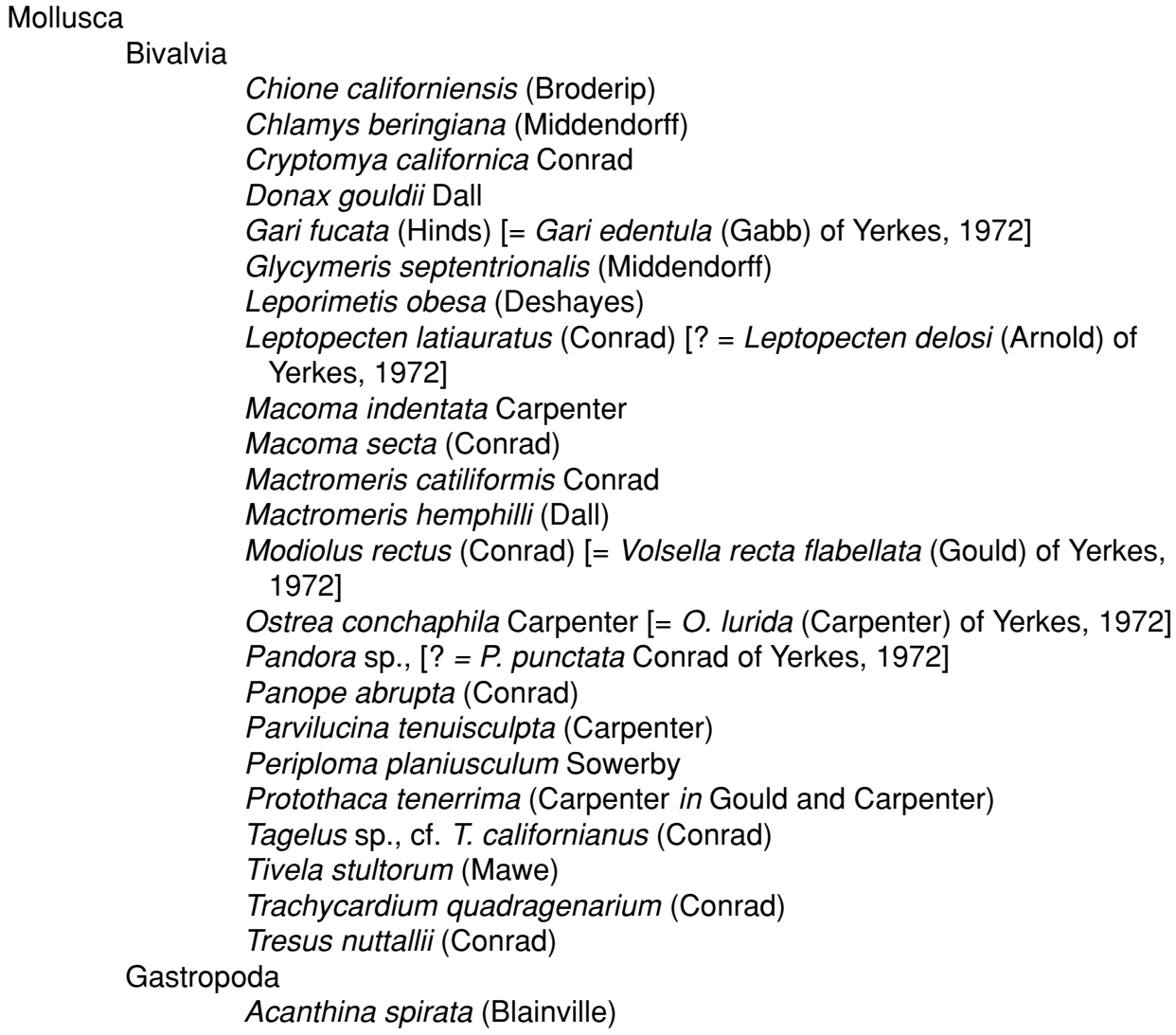


Acteocina harpa (Dall)

Astyris gausapata (Gould) [= Mitrella carinata (Hinds) of Yerkes, 1972]

Bursa californica (Hinds)

Cancellaria tritonidae (Gabb)

Conus californicus Hinds

Crassispira zizyphus Berry [= Crassispira montereyensis (Stearns) of

Yerkes, 1972]

Crucibulum spinosum (Sowerby)

Cryptonatica affinis (Gmelin) [= Cryptonatica clausa (Broderip \&

Sowerby) of Yerkes, 1972]

Cymatosyrinx hemphilli (Stearns)

Epitonium indianorum (Carpenter)

Erato vitellina Hinds

Kurtziella variegata Carpenter

Lacuna unifasciata Carpenter

Littorina scutulata Gould

Mitrella tuberosa (Carpenter)

Nassarius sp., cf. N. cerritensis (Arnold)

Nassarius mendicus (Gould) [= N. mendicus cooperi (Forbes) of Yerkes, 1972]

Nassarius perpinguis (Hinds)

Nassarius tagula (Reeve)

Neptunea tabulata (Baird) [= Neptunea tabulata colmanis (Martin) of Yerkes, 1972]

Neverita reclusiana (Deshayes)

Olivella baetica Carpenter [? = Olivella pedroana (Conrad) of Yerkes, 1972]

Olivella biplicata (Sowerby)

Ophiodermella mercedensis (Martin)

Polinices lewisii (Gould)

Polygireulima rutila (Carpenter)

Pseudomelatoma sp., cf. P. pencillata (Carpenter)

Terebra pedroana Dall

Turbonilla sp.

Scaphopoda

Volvulella cylindrica Carpenter

Dentalium neohexagonum Sharp \& Pilsbry

Arthropoda

Dentalium pretiosum pretiosum Sowerby

Crustacea

Balanus sp. [= B. concavus Bornn of Yerkes, 1972]

Echinodermata

Echinodea

Dendraster venturensis Kew

Field No.: F-10. Sec. 18, T. 3 S., R. 10 W., 1,800' N and 375' W of SE corner of section, La Habra 7.5' Quadrangle. Collected by C. W. Hoskins. Identified by C. W. Hoskins (Yerkes, 1972, p. C59).

Mollusca

Bivalvia

Cyathodonta pedroana Dall [? $=$ C. undulata Conrad of Yerkes, 1972]

Epilucina californica (Conrad)

Lyropecten cerrosensis (Gabb) - not found but if present would suggest upper fauna.

Macoma sp.,[= M. inconspicua (Broderip \& Sowerby) of Yerkes, 1972]

Macoma indentata Carpenter

Macoma secta (Conrad)

Miodontiscus prolongatus (Carpenter)

Mytilus sp., cf. M. californianus Conrad

Nuculana taphria (Dall)

Nutricola tantilla (Gould) [= Nutricola lordi (Baird) of Yerkes, 1972]

Panope abrupta (Conrad)

Pecten bellus (Conrad) 


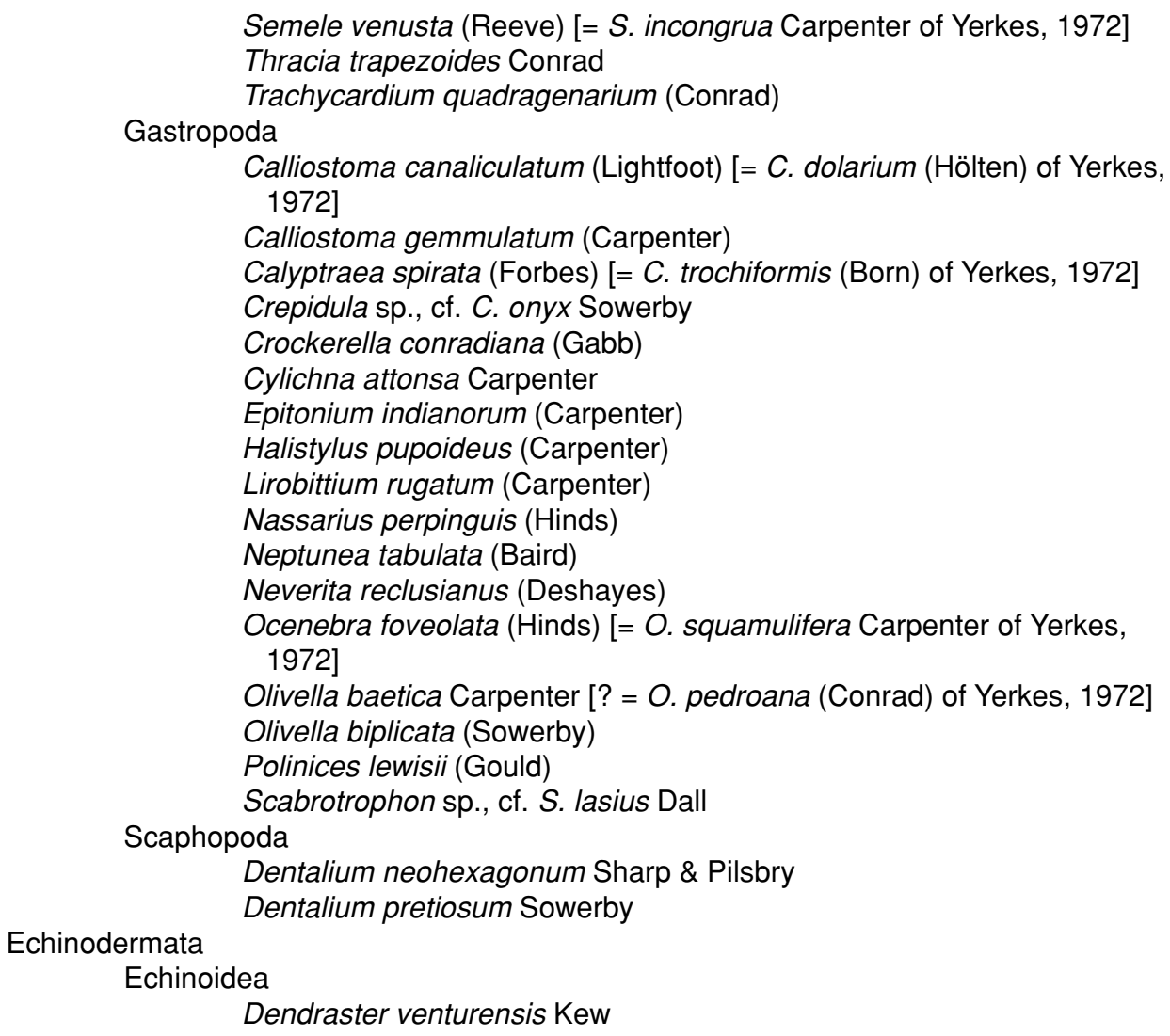

Field No.: F-11. Sec. 17, T. 3 S., R. 10 W., 55' N and 2,430' W of SE corner of section, La Habra 7.5' Quadrangle. Collected by C. W. Hoskins. Identified by C. W. Hoskins (Yerkes, 1972, p. C59).

Mollusca

Bivalvia

Compsomyax subdiaphana (Carpenter)

Cyathodonta pedroana Dall [? = C. undulata Conrad of Yerkes, 1972]

Gari fucata (Hinds) [= Gari edentula (Gabb) of Yerkes, 1972]

Lucinoma annulata (Reeve)

Macoma secta (Conrad)

Pecten bellus (Conrad)

Siliqua sp.

Gastropoda

Tellina bodegensis Hinds

Acteon sp. [= Acteon traskii Stearns of Yerkes, 1972]

Calliostoma sp., cf. C. ligatum (Gould)

Conus californicus Hinds

Crepidula princeps Conrad

Fusinus arnoldi (Cossmann)

Nassarius sp., cf. N. fossatus (Gould)

Nassarius perpinguis (Hinds)

Ocenebra foveolata (Hinds) [= O. fusconotata (Dall) of Yerkes, 1972]

Polinices draconis Dall

Polinices lewisii (Gould)

Field No.: F-12. Sec. 18, T. 3 S., R. 10 W., 1,400' N and 1,360' W of SE corner of section, La Habra 7.5' Quadrangle. Collected by C. W. Hoskins. Identified by C. W. Hoskins (Yerkes, 1972, p. C59).

Mollusca

Bivalvia

Acila castrensis (Hinds)

Cyathodonta pedroana Dall $[?=$ C. undulata Conrad of Yerkes, 1972]

Mytilus trossuslus (Gould)

Panope abrupta (Conrad) 


Pecten bellus (Conrad)
Pododesmus macroschisma (Deshayes)
Saxidomus nuttalli (Conrad)
Solen sicarius Gould
Gastropoda
Calliostoma gemmulatum (Carpenter)
Crepidula princeps Conrad
Megasurcula carpenteriana (Gabb)
Turritella cooperi Carpenter
Echinodermata
Echinodea
Dendraster sp., D. venturaensis Kew

Field No.: F-13. Sec. 18, T. 3 S., R. 10 W., 1,210' N and 980' E of SW corner of section, La Habra 7.5' Quadrangle. Collected by C. W. Hoskins. Identified by C. W. Hoskins (Yerkes, 1972, p. C59). Middle fauna. Mollusca Bivalvia Chlamys behringiana (Middendorff) Compsomyax subdiaphana (Carpenter) Cyclocardia sp., aff. C. occidentalis (Conrad) Glycymeris septentrionalis (Middendorff) Irusella lamellifer (Conrad)

Pandora wardiana Adams [= Pandora grandis Dall of Yerkes, 1972] Patinopecten caurnus (Gould) Gastropoda Pododesmus macroschisma (Deshayes)

Nassarius perpinguis (Hinds)

Field No.: F-14. Sec. 18, T. 3 S., R. 10 W., 1,560' N and 2,040' W of SE corner of section, La Habra 7.5' Quadrangle. Collected by C. W. Hoskins. Identified by C. W. Hoskins (Yerkes, 1972, p. C59). Mollusca

$$
\begin{aligned}
& \text { Bivalvia } \\
& \text { Irusella lamellifer (Conrad) } \\
& \text { Gastropoda } \\
& \text { Fusinus arnoldi (Cossmann) } \\
& \text { Turritella cooperi Carpenter }
\end{aligned}
$$

Field No.: F-15. Sec. 18, T. 3 S., R. 10 W., 1,825' N and 1,490' W of SE corner of section, La Habra 7.5' Quadrangle. Collected by C. W. Hoskins. Identified by C. W. Hoskins (Yerkes, 1972, p. C59).

Mollusca

Bivalvia

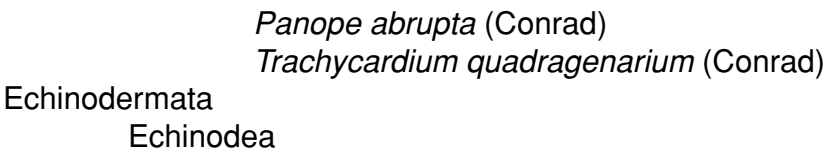

Dendraster sp., D. venturaensis Kew

Field No.: F-16. Sec. (32), T. 2 S., R. 10 W., artificial cut 1,735' N and 600' W of SE corner of section, La Habra 7.5' Quadrangle. Collected by R. F. Yerkes. Identified by W. H. Holman and J. G. Vedder (Yerkes, 1972, p. C59).

Mollusca

Bivalvia

Panope sp., cf. P. abrupta (Conrad) 